\title{
Carbon flux from live peat, peat mix, and mineral soil transplant cells for wetland reclamation, Fort McMurray, Alberta
}

\author{
by \\ Yousuf Tariq Farooq \\ B. Sc. Environmental Science (Hons), Carleton University Ottawa, Ontario, Canada, \\ 2008
}

\begin{abstract}
A thesis Submitted to the Faculty of Graduate Studies and Research in partial fulfilment of the requirements for the degree of M.Sc
\end{abstract}

Department of Geography \& Environmental Studies

Carleton University Ottawa, Ontario, Canada

January 2011

(C) 2011, (Yousuf Tariq Farooq) 
Library and Archives

Canada

Published Heritage

Branch

395 Wellington Street

Ottawa ON K1A ON4

Canada
Bibliotheque et

Archives Canada

Direction du

Patrimoine de l'édition

395 , rue Wellington

Ottawa ON K1A ON4

Canada
Your file Votre reférence

ISBN: 978-0-494-81691-2

Our file Notre référence

ISBN: 978-0-494-81691-2

\section{NOTICE:}

The author has granted a nonexclusive license allowing Library and Archives Canada to reproduce, publish, archive, preserve, conserve, communicate to the public by telecommunication or on the Internet, loan, distribute and sell theses worldwide, for commercial or noncommercial purposes, in microform, paper, electronic and/or any other formats.

The author retains copyright ownership and moral rights in this thesis. Neither the thesis nor substantial extracts from it may be printed or otherwise reproduced without the author's permission.
AVIS:

L'auteur a accordé une licence non exclusive permettant à la Bibliothèque et Archives Canada de reproduire, publier, archiver, sauvegarder, conserver, transmettre au public par télécommunication ou par l'Internet, prêter, distribuer et vendre des thèses partout dans le monde, à des fins commerciales ou autres, sur support microforme, papier, électronique et/ou autres formats.

L'auteur conserve la propriété du droit d'auteur et des droits moraux qui protège cette thèse. $\mathrm{Ni}$ la thèse ni des extraits substantiels de celle-ci ne doivent être imprimés ou autrement reproduits sans son autorisation.
In compliance with the Canadian Privacy Act some supporting forms may have been removed from this thesis.

While these forms may be included in the document page count, their removal does not represent any loss of content from the thesis.
Conformément à la loi canadienne sur la protection de la vie privée, quelques formulaires secondaires ont été enlevés de cette thèse.

Bien que ces formulaires aient inclus dans la pagination, il n'y aura aucun contenu manquant.

\section{Canadä}




\begin{abstract}
Oil sand mining in Fort McMurray, Alberta disturbs large areas of wetlands. By definition, peat-forming wetlands sequester carbon over the long-term. By assessing the carbon balance of reclaimed wetlands, the success of reclamation efforts may be monitored. This study compares the carbon balance of 28 different test sites (cells) including live peat treatments, peat mix /mineral soil treatments, and nearby natural bog sites. The net ecosystem exchange (NEE) of carbon dioxide as well as the rate of respiration ( $\mathrm{R})$, of each site was measured using in situ closed chambers. Leaf Area Index (LAI), soil temperature, and soil moisture influenced rates of photosynthesis, $\mathrm{R}$ and NEE throughout May-August of 2009. Live summer treatments were able to sequester more carbon than live winter treatments. However, of all the 28 test cells, the peat mix winter treatments sequestered the greatest amount carbon, as well as exhibited similar NEE to those of the natural bog.
\end{abstract}




\section{Acknowledgements}

I would like to thank Dr. Sean Carey, Dr. Elyn Humphreys, Dr. Michael Treberg, Dr Yinsuo Zhang and my family and friends for their support and help during my education as a master's student. 


\section{Table of Contents}

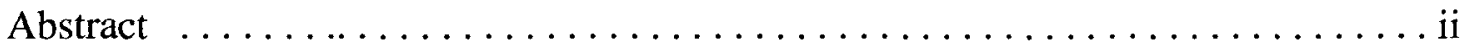

Acknowledgements $\ldots \ldots \ldots \ldots \ldots \ldots \ldots \ldots \ldots \ldots \ldots \ldots \ldots \ldots \ldots \ldots \ldots \ldots$ ii

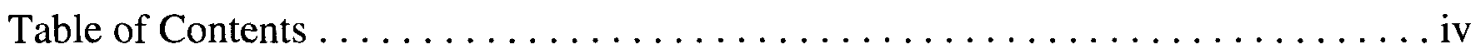

List of tables $\ldots \ldots \ldots \ldots \ldots \ldots \ldots \ldots \ldots \ldots \ldots \ldots \ldots \ldots \ldots \ldots \ldots$

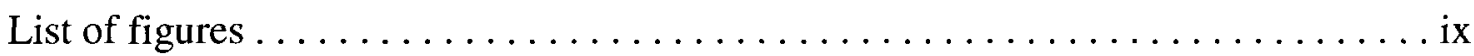

List of symbols and abbreviations $\ldots \ldots \ldots \ldots \ldots \ldots \ldots \ldots \ldots \ldots \ldots \ldots \ldots$

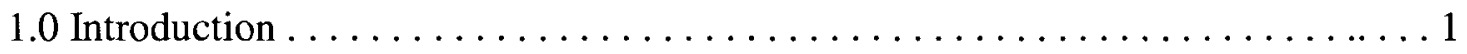

2.0 Literature review $\ldots \ldots \ldots \ldots \ldots \ldots \ldots \ldots \ldots \ldots \ldots \ldots \ldots \ldots \ldots \ldots \ldots$

2.1 Characteristics \& formation of wetlands. . . . . . . . . . . 4

2.2 Peatland physiology and controls on its carbon balance $\ldots \ldots \ldots \ldots \ldots$

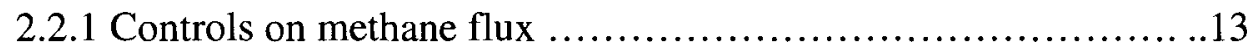

2.3 Impact of peat harvesting on the carbon budget $\ldots \ldots \ldots \ldots \ldots \ldots$

2.4 Important reclamation parameters and techniques used in the literature ......17

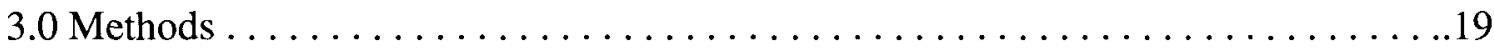

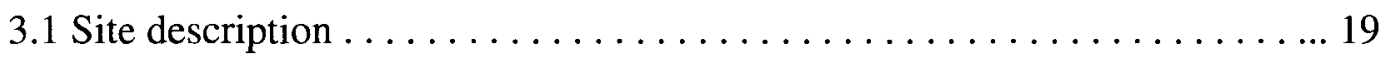

3.2 Experimental Design and data collection $\ldots \ldots \ldots \ldots \ldots \ldots$

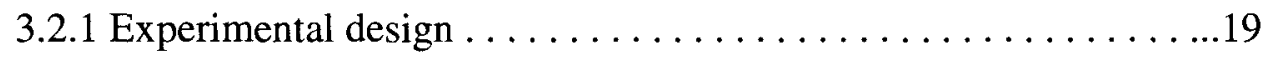

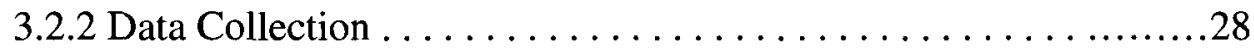

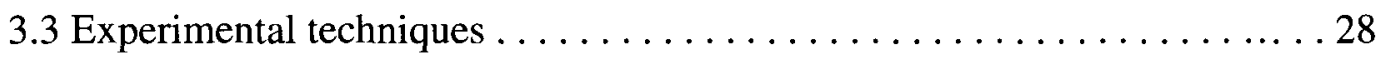

3.3.1 Closed chamber NEE measurement technique. . . . . . . . . . 28

3.3.2 Static chamber technique ................. 30 
3.3.3 Ancillary measurements . ..................... 31

3.3.4 Leaf Area Index (pin drop method). ................. 31

3.3.5 Volumetric water content and Soil temperature ............32

3.4 Data processing and analysis $\ldots \ldots \ldots \ldots \ldots \ldots \ldots \ldots \ldots \ldots \ldots \ldots \ldots \ldots$

3.4.1 Daily and Seasonal NEE, GEP, R Calculations .............33

3.4.2 NEE, R, and GEP processing and analysis ............. 33

3.4.3 Closed Chamber Methane flux and $\mathrm{CO}_{2}$ processing. ....... 36

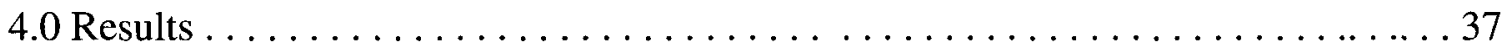

4.1 2009 Growing Season Climate.............................................

4.2 Variability in NEE, R, GEP, and methane flux among different treatments during 2009 growing season .......................... 40

4.3 LAI, Surface Temperature, and VWC trends. ............... 46

4.3.1 LAI trends during 2009 growing season . . . . . . . . . . . .46

4.3.2 Surface temperature trends during 2009 growing season . . . . . .48

4.3.3 VWC trends during 2009 growing season ............. 50

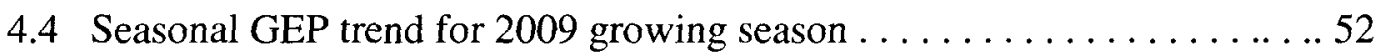

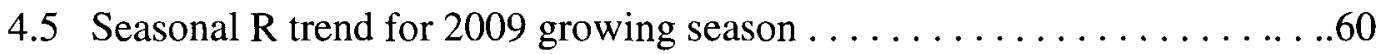

4.6 Seasonal NEE trend for 2009 growing season . . . . . . . . . . . . . ..69

4.7 Seasonal $\mathrm{CH}_{4}$ trend for 2009 growing season $\ldots \ldots \ldots \ldots \ldots \ldots \ldots$

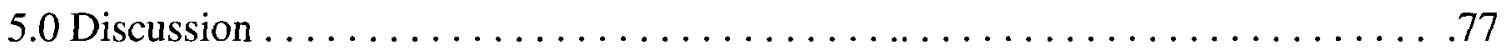

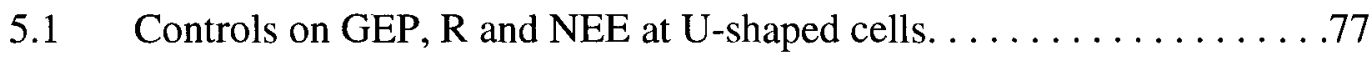

5.2 Treatment effects on GEP, R and NEE at U-shaped cells .... . . . ......79

5.2 .1 Compaction $\ldots \ldots \ldots \ldots \ldots \ldots \ldots \ldots \ldots \ldots \ldots \ldots$

5.2 .2 Peat depth $\ldots \ldots \ldots \ldots \ldots \ldots \ldots \ldots \ldots \ldots \ldots \ldots \ldots \ldots . . . . .60$ 
5.2 .3 Winter Vs Summer . . . . . . . . . . . . . ...80

5.2.4 Soil type (Peat mix Vs live Vs mineral) . . . . . . . . . . .81

$5.3 \quad$ NEE, GEP, R comparison with the literature ............ 83

5.4 Methane flux at U-shaped cells and natural site during $2009 \ldots \ldots$. . . 89

6.0 Conclusions and Recommendations $\ldots \ldots \ldots \ldots \ldots \ldots \ldots \ldots \ldots \ldots$

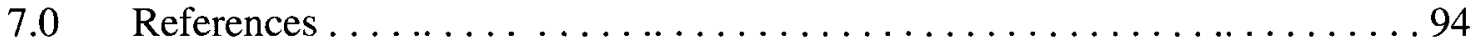




\section{List of Tables}

Table 3.1: Details of the treatments of each treatment at a U-shaped site during the growing season of 2009 ---

Table 3.2: Images of a selection of cells: live summer treatment, live winter treatment, and peat mix summer treatment -

Table 3.3: Images of a selection of cells: peat mix winter treatments, peat mix treatment with mine water, mineral soil treatments, and natural site -

Table 4.1: Monthly average air temperature (Ta) and rainfall data for 2009 growing season at the U-shaped research site, Environment Canada site (from the Fort McMurray airport) and 30-year climate normal (1971-2000) (CN) reported for Fort McMurray, Alberta. For August, research and Environmental Canada site have data only for first 15 days, while for $\mathrm{CN}$ it is for full month

Table 4.2: MANOVA (F-values and P-values) and Tukey's HSD results for the full growing season. The significance level (p) was 0.05 and treatment with the same letters were not significantly different. The calculated $F$ and degree of freedom (df) is also shown

Table 4.3: Turkey's HSD results for NEE, GEP, R and Methane flux based on treatments during early, mid and late summer seasons. The seasonal differences with in the same treatments/group were also shown and whether there is a significance difference with in groups were analysed based on the alphabetical letters. For example: Live summer treatment is represented by (A), therefore, small alphabetical letters for NEE, GEP and R were compared for each A during early, mid and late summer seasons. The significance level (p) was $0.05 \%$ and treatments with even one similar alphabet are not significantly different to each other. However, different letters among treatments reveals significance

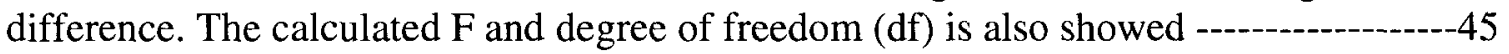

Table 4.4: Average LAI $\left(\mathrm{m}^{2} / \mathrm{m}^{2}\right)$ values with standard deviation for each treatment during three early, mid and late summer seasons. Early season is from DOY138-DOY 164, mid season is from DOY 165-195 and late season is from DOY 196-DOY 228

Table 4.5: Average surface temperature with standard deviation for each treatment types during early, mid and late summer seasons

Table 4.6: Average VWC values with standard deviation for each treatment type during early, mid and late summer seasons $-51$

Table 4.7: Summary table of the GEP for different treatments during early, mid, late and full growing season $-59$ 
Table 4.8: Summary table of the R for different treatments during early, mid, late and full growing season.

Table 4.9: Summary table of the NEE for different treatments during early, mid, late and full growing season

Table 4.10: Average growing season $\mathrm{CH}_{4}$ flux with standard deviation for different treatments

Table 5.1: Comparison of NEE, GEP, and $\mathrm{R}$ with previous literature on restored and natural bogs based on similar DOY criteria used for the current study. In some studies values were reported in $\mathrm{g} \mathrm{CO}_{2} \mathrm{~m}^{-2} \mathrm{day}^{-1}$ and hence they were converted into $\mu \mathrm{mol} \mathrm{m} \mathrm{m}^{-2} \mathrm{~s}^{-1}$. However, original values in $\mathrm{g} \mathrm{CO}_{2} \mathrm{~m}^{-2}$ day $^{-1}$ were also reported inside the bracket-------88 


\section{List of Figures}

Figure 2.1: Representing distinct peat soil layers catotelme and acrotelme -------------8

Figure 3.1: Exact summer treatments with block dimensions and treatments -----------20

Figure 3.2: A view of complete U-shaped cell treatments view and the Mildred Lake settling basin and natural sites 22

Figure 3.3: Pictorial representation of NEE system with acrylic chamber and LI-190 quantum sensor $-29$

Figure 3.4: Pictorial representation of pin drop leaf area index instrument $-32$

Figure 4.1: Daily rainfall from 1st May to 16th August, 2009 recorded within $200 \mathrm{~m}$ of Ushaped site $-38$

Figure 4.2: average daily air temperature for the growing season of 2009 $-38$

Figure 4.3: Average GEP, R, NEE during early summer, mid summer, late summer and full summer period for the different treatment groups. LS are live summer treatments, LW are live winter treatments, PS are peat mix summer treatments, PW are peat mix winter treatments, MS are mineral soil treatments, and NS are natural sites

Figure 4.4: Seasonal trends in GEP for live treatments with no compaction for both summer (a) and winter (b) during the growing season of 2009 $-55$

Figure 4.5: Seasonal trends in GEP for live treatments with compaction for both summer (a) and winter (b) during the growing season of 2009 $-55$

Figure 4.6: Seasonal trends in GEP for peat mix treatments with no compaction for summer (a) and winter (b) during the growing season of 2009 56

Figure 4.7: Seasonal trends in GEP for peat mix treatments with compaction for summer (a) and winter (b) during the growing season of 2009 $-56$

Figure 4.8: Seasonal trends in GEP for peat mix treatments with mine water during the growing season of 2009 --

Figure 4.9: Seasonal trends in GEP for mineral soil treatments during the growing season of 2009

Figure 4.10: Seasonal trends in GEP for natural sites during the growing season of 2009-- 
Figure 4.11: Seasonal trends in $\mathrm{R}$ for live treatments with no compaction for summer (a) and winter (b) during the growing season of 2009 $-62$

Figure 4.12: Seasonal trends in $\mathrm{R}$ for live treatments with compaction for summer (a) and winter (b) during the growing season of 2009 $-62$

Figure 4.13: Seasonal trends in $\mathrm{R}$ for peat mix treatments with no compaction for summer (a) and winter (b) during the growing season of 2009 $-63$

Figure 4.14: Seasonal trends in $\mathrm{R}$ for peat mix treatments with compaction for summer (a) and winter (b) during the growing season of 2009 63

Figure 4.15: Seasonal trends in $\mathrm{R}$ for peat mix treatments with mine water during the growing season of 2009 $-64$

Figure 4.16: Seasonal trends in $\mathrm{R}$ for mineral soil treatments during the growing season of 2009 $-64$

Figure 4.17: Seasonal trends in $\mathrm{R}$ for natural sites during the growing season of 2009 -----

Figure 4.18: Seasonal trends in NEE for live treatments with no compaction for summer (a) and winter (b) during the growing season of 2009 $--70$

Figure 4.19: Seasonal trends in NEE for live treatments with compaction for summer (a) and winter (b) during the growing season of 2009

Figure 4.20: Seasonal trends in NEE for peat mix treatments with no compaction for summer (a) and winter (b) treatment during the growing season of 2009 $-71$

Figure 4.21: Seasonal trends in NEE for peat mix treatments with compaction for summer (a) and winter (b) during the growing season of 2009 $-71$

Figure 4.22: Seasonal trends in NEE for peat mix treatments with mine water during the growing season of 2009 72

Figure 4.23: Seasonal trends in NEE for mineral soil treatments during the growing season of 2009 72

Figure 4.24: Seasonal trends in NEE for natural sites during the growing season of 2009-- 


\section{List of Symbols and Abbreviations}

\begin{tabular}{|c|c|c|}
\hline Symbol & Units & Definition \\
\hline$\alpha$ & $\mathrm{mol} \mathrm{CO}_{2} \mathrm{~mol}^{-1}$ photons & apparent quantum yield \\
\hline $\mathrm{A}^{*}$ & & Significance level \\
\hline$\Delta$ & & change \\
\hline A & $\mathrm{m}^{2}$ & chamber surface area \\
\hline $\mathrm{dC} / \mathrm{dt}$ & $\begin{array}{l}\mu \mathrm{mol} \mathrm{CO}_{2} \\
\mathrm{~mol}^{-1} \text { dry air s } \\
\text { time }\end{array}$ & change in $\mathrm{CO}_{2}$ mixing ratio with \\
\hline DIC & & Dissolved Inorganic Carbon \\
\hline DOC & & Dissolved Organic Carbon \\
\hline$\overline{D O Y}$ & & Day of Year \\
\hline ES & & Early Summer(DOY 138-164) \\
\hline $\mathrm{FCO}_{2}$ & $\mu \mathrm{mol} \mathrm{CO} 2 \mathrm{~m}^{2} \mathrm{~s}^{-1}$ & $\mathrm{CO}_{2}$ flux \\
\hline FID & & Flame-ionization detector \\
\hline FM & & Fort McMurray \\
\hline GC & & gas chromatograph \\
\hline GEP & $\mathrm{mol} \mathrm{CO} \mathrm{m}^{2} \mathrm{~s}^{-1}$ & Gross ecosystem production \\
\hline IRGA & & Infra red gas analyzer \\
\hline LS & & Late summer (DOY 196-228) \\
\hline LAI & $\begin{array}{l}\mathrm{m}^{2} \text { leaf area } \\
\mathrm{m}^{-2} \text { surface area }\end{array}$ & Leaf area index \\
\hline $\mathrm{MH}_{2} \mathrm{O}$ & $\mathrm{mol} \mathrm{H}_{2} \mathrm{O} \mathrm{mol}^{-1}$ dry air & $\mathrm{H}_{2} \mathrm{O}$ mixing ratio \\
\hline
\end{tabular}




\begin{tabular}{|l|l|l|}
\hline MS & & Mid summer (DOY 165-195) \\
\hline NEE & $\mu \mathrm{mol} \mathrm{CO} \mathrm{m}^{2} \mathrm{~s}^{-1}$ & net ecosystem exchange of $\mathrm{CO}_{2}$ \\
\hline $\mathrm{P}$ & $\mathrm{Pa}$ & mean air pressure \\
\hline PAR & $\mu \mathrm{mol}$ photons $\mathrm{m}^{2} \mathrm{~s}^{-1}$ & photosynthetically active radiation \\
\hline PPFD & $\mu \mathrm{mol}_{,}$photons $\mathrm{m}^{2} \mathrm{~s}^{-1}$ & photosynthesis photon flux density \\
\hline PLAI & $\begin{array}{l}\mathrm{m}^{2} \text { leaf area/ } \\
\mathrm{m}^{-2} \text { surface area }\end{array}$ & pin drop leaf area index \\
\hline $\mathrm{R}$ & $\mu \mathrm{mol} \mathrm{CO} \mathrm{m}^{2} \mathrm{~s}^{-1}$ & total respiration \\
\hline $\mathrm{R} *$ & $\mathrm{~J} \mathrm{~mol}^{-1} \mathrm{~K}^{-1}$ & Ideal gas constant \\
\hline Ta & ${ }^{\circ} \mathrm{C}$ & air temperature \\
\hline Tch & $\mathrm{K} \mathrm{or}{ }^{\circ} \mathrm{C}$ & mean chamber temperature \\
\hline V & $\mathrm{m}^{3}$ & chamber volume \\
\hline VWC & $\%$ & Volumetric water content \\
\hline
\end{tabular}




\subsection{Introduction}

Alberta's oil sands industry is an important part of Canada's economy, representing almost one-third of the world's total oil reserves (Alberta Geological Survey 2008). To date, mining has resulted in $1200 \mathrm{~km}^{2}$ of land disturbance, which is expected to increase in the next few decades to $2000 \mathrm{~km}^{2}$, (Carey 2008). In accordance with Alberta's Protection Enhancement Act, Water Act, and Land Act, mining industries are primarily responsible for bringing back the disturbed land into a functional landscape, which can mimic the natural ecosystem. These reclaimed landscapes need to replicate natural watershed functions, such as habitat functioning (which provides habitat for various species), production functioning (production of biomass), and carrier functioning (transportation of dissolved minerals) (Elshorbagy et al. 2005).

Wetland ecosystems are important elements of Alberta's landscape. They cover approximately $21 \%$ of the total provincial area and provide many ecosystem services (Wilson et al. 2001). Wetlands are ecologically important as over 300 species are dependent on them for food, shelter and habitat (Wilson et al. 2001). They sequester atmospheric carbon dioxide in the soil for long periods of time and help reduce atmospheric carbon dioxide (Wilson et al. 2001; National Wetland Working Group 1997).

Ongoing mining activity in northern Alberta destroys many ecosystems, including wetlands. Wetland reclamation is reliant on the re-establishment of the peat hydrological properties such as peat depth, water table, soil moisture, and soil temperature, which help control the net ecosystem productivity, nutrient cycle, vegetation type, and peat decomposition rates of wetlands. At present, it is unclear how hydrological properties of 
the affected wetland can be restored successfully, as there is limited data available for wetland reclamation in the northern boreal zone near Fort McMurray. However, many wetlands have been previously reclaimed in environments in Quebec and Manitoba (Waddington et al. 2010; Waddington and Warner 2001; Lafleur et al. 2001; Joiner et al. 1999). Soil thickness, LAI, soil moisture, and soil temperature were observed to be governing parameters in re-establishing the wetlands in central Quebec and Manitoba as they help determine vegetation health and rates at which bacterial activity takes place (Waddington et al. 2010; Waddington and Warner 2001; Lafleur et al. 2001; Joiner et al. 1999). In comparison to that of Fort McMurray sub-humid continental climate, Quebec has subarctic climate. However, Manitoba experiences similar climatic conditions as Fort McMurray.

Oil sand companies are trying to construct wetlands in post-mining landscapes in Fort McMurray, Alberta. At present, it is unclear as to which type of reclamation strategies work most effectively in order to establish wetland vegetation as well as hydrological properties. Therefore, experiments are being conducted at smaller scale to assess the most appropriate reclamation strategy. A series of experimental plots, termed U-shaped cells, have been constructed on Syncrude Canada's Mildred Lake mine, Fort McMurray, to investigate the performance of different peat soil covers under different combinations of treatments. Based on the results of these experiments, information will be provided to mine operators to assess appropriate and cost effective strategies to be used for wetland establishment. The data obtained will also improve our general understanding of wetland reclamation, particularly in the boreal region of northern Alberta. 
The successful development and health of wetlands can, in part, be evaluated by their carbon balance where it is expected that the vegetation will sequester more atmospheric carbon than is lost from the ecosystem, at least during the growing season. In this thesis, the carbon balance of test cells will be compared with a nearby bog from which the peat soils were obtained, and with literature data from natural wetland sites, to assess the effectiveness of different reclamation strategies. The primary objectives of this research are to:

i) measure the carbon balance of various live, peat mix treatments under specific management strategies,

ii) compare the carbon balance of live, peat mix soil treatments to a nearby natural site and to published data from boreal wetlands, and

iii) assess the factors that control the carbon dynamics of the live and peat mix treatments. 


\subsection{Literature review}

\subsection{Characteristics and formation of wetlands}

Wetlands are areas where the water table is located either at, or above, the land surface for a prolonged period to promote the formation of hydric soils in which decomposition of organic matter is limited (Tarnocai 1988; National Wetland Working Group 1997). Wetlands cover $\sim 14 \%$ of the total land mass of Canada, representing $\sim 25 \%$ of the world's wetlands (Price and Waddington 2000). Wetlands are found between latitudes $60^{\circ} \mathrm{S}$ and $80^{\circ} \mathrm{N}$, with the majority concentrated in the boreal and subarctic zones of the northern hemisphere (Lehner and Döll 2004).

Climate and topography are key in the development and distribution of wetlands (Zoltai 1988). The latitudinal and meridianal gradient describes the influence of climate on wetland distribution. Latitudinal gradient govern the amount of incoming solar radiation; consequently controlling the total ecosystem productivity and decomposition rates (Frolking et al. 1998). Whereas, in the Canadian context, the meridianal gradient in part governs the precipitation patterns and moisture availability (Zoltai 1988). The northern Alberta has sub-humid climate as during most of the year, potential evapotranspiration rates (PET) surpass the amount of precipitation. This current research took place in Fort McMurray, Alberta. In general, Fort McMurray region is a water deficit region. On an average, Fort McMurray receives $445 \mathrm{~mm}$ of precipitation annually. However, on an average, evapotranspiration rates in Fort McMurray are approximately $575 \mathrm{~mm}$ during a year based on the climate normal data. Therefore, long term climate data shows the evidence of water deficit and presence of sub-humid climate in Fort McMurray (Petrone et al. 2011; Brown et al. 2010; Environmental Canada 2007). 
Landscape topography and drainage properties also influence the disposition of wetlands. Typically, lower elevation zones with flow accumulation and reduced drainage results in the formation of saturated soils. Therefore, lack of drainage is an essential component for the formation of the wetland. In these areas, organic matter accumulates as dead leaves and vegetation fall to the ground. Moss and other wetland vegetation species' growth are promoted. The anaerobic conditions in wetland soils results in low decomposition rates. Over long periods of time, the low and partial decomposition of organic material results in the accumulation of organic soil that can range in thickness from centimetres to many metres (Kennedy and Mayer 2002). Wetlands are classified into two major categories: mineral wetlands and peatlands. The mineral wetland soils are poorly developed due to frequent and large changes in water table depth, hydraulic conductivity and salt concentrations. Examples of mineral wetlands are swamps and marshes. Peatlands are those wetlands in which at least $40 \mathrm{~cm}$ of organic soil has accumulated. Bogs and fens are examples of peatlands (National Wetland Working Group 1997).

Bogs mainly form in cool climates where soils lack oxygen and drainage is poor. They are nutrient-deficient systems; their only source of nutrients is precipitation. In Canada, bog vegetation typically includes Sphagnum moss, ericaceous shrubs and may include spruce, and tamarack trees (Lafleur 2009). In contrast, fens are often dominated by graminoid species such as sedges and grass. However, the may also be treed and typically have a surface cover of either Sphagnum or brown mosses. Fens receive water from precipitation and from groundwater and runoff from surrounding mineral uplands. Fens can be divided into two categories based on their water chemistry: rich or poor. Rich 
fens, in contrast to poor fens, have higher soil $\mathrm{pH}$ due to greater concentrations of mineral nutrients (Lafleur 2008; Lafleur 2009).

At present, soil carbon content in peatlands is estimated to be in between $329 \times 10^{15} \mathrm{~g}$ and $525 \times 10^{15} \mathrm{~g}$ globally (Bridgham et al. 2006). The net carbon storage in a peatland is a function of its total input and output (equation 2.1).

$\Delta$ storage $($ carbon $)=\left(\right.$ photosynthesis $\left.+\operatorname{runoff}_{\text {in }}\right)-\left(\right.$ total respiration + runoff $\left._{\text {out }}\right)$

The net input is dependent on the amount of photosynthesis, inflow of dissolved organic carbon (DOC), and inflow of dissolved inorganic carbon (DIC). Photosynthesis is a process in which synthesis of carbohydrate takes place using light energy, water and $\mathrm{CO}_{2}$. Vascular plants take in atmospheric $\mathrm{CO}_{2}$ through their leaf stoma. Meanwhile, in nonvascular plants such as mosses, gas exchange occurs through their cell wall. The process of photosynthesis sequesters the atmospheric carbon and governs the total gross ecosystem production (GEP). The net loss of carbon from the wetlands is a result of the total ecosystem respiration $(\mathrm{R})$, outflow of DOC, and outflow of DIC. Respiration is a metabolic process where oxidation of carbohydrates into smaller units provides energy for the organism. Waste products such $\mathrm{CO}_{2}$ or $\mathrm{CH}_{4}$ are produced and may be released into the atmosphere. In plants, respiration is referred to as autotrophic respiration. Additionally, decay of organic matter due to microbial activities in soil also releases $\mathrm{CO}_{2}$ (predominantly associated with aerobic respiration) and $\mathrm{CH}_{4}$ (predominantly associated with anaerobic respiration) and is known as heterotrophic respiration. The sum of autotrophic and heterotrophic respiration resulting in $\mathrm{C}$ emissions accounts for the total 
ecosystem respiration. In this study, ecosystem respiration involving emissions of $\mathrm{CO}_{2}$ (R) is treated separately from emissions of $\mathrm{CH}_{4}$. The net ecosystem exchange of $\mathrm{CO}_{2}$ (NEE) is defined as NEE $=\mathrm{R}-\mathrm{GEP}$. In this study, negative values of NEE indicate uptake of $\mathrm{CO}_{2}$ by the ecosystem while positive values indicate loss of $\mathrm{CO}_{2}$ to the atmosphere. Positive GEP indicate uptake of $\mathrm{CO}_{2}$ by the plants while positive $\mathrm{R}$ indicate loss of $\mathrm{CO}_{2}$. 


\subsection{Peatland physiology and controls on carbon balance}

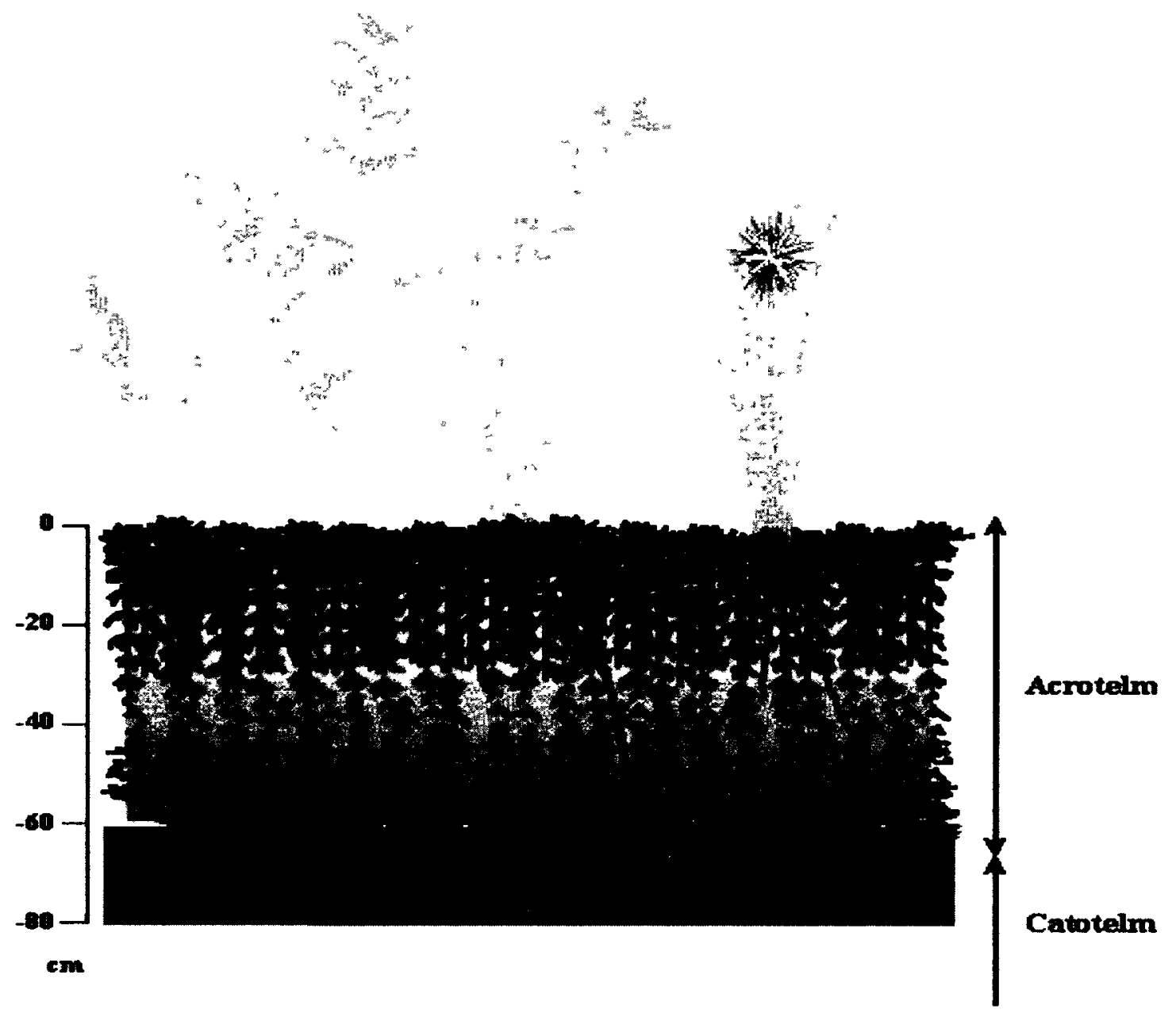

Figure 2.1: Representing distinct peat soil layers catotelme and acrotelme (Payette \& Rochefort 2001).

In peatlands, there are two distinct soil layers, the catotelm and the acrotelm (Figure 2.1) (Quinty and Rochefort 2003). The top layer is the acrotelm and it is composed of living moss and dead plant material. The water table depth fluctuates in the acrotelm during and between seasons, affecting the aerobic and anaerobic respiration rates. The acrotelm is loosely packed with very high porosity, which allows rapid flow of water through it (Quinty and Rochefort 2003). 
The lower layer of the peat is the catotelm and is permanently located below the water table, where slower anaerobic respiration results in reduced peat decomposition. The water flow in this layer is restricted due to higher compaction and lower hydraulic conductivities (Quinty and Rochefort 2003; Holden 2005).

The depth of the water table from the surface varies with precipitation events and evapotranspiration rates. Higher water tables promote anaerobic conditions throughout the soil profile, resulting in increased anaerobic bacterial activity. Enhanced anaerobic respiration results in lower and incomplete soil organic carbon decomposition. These conditions produce $\mathrm{CH}_{4}$, which reaches the atmosphere through diffusion, ebullition and by plant transport (Price and Waddington 2000). Therefore, higher $\mathrm{CH}_{4}$ emissions are usually observed in peatlands during periods when water table is high. Conversely, when the water table is lower, increased oxygen levels promote the oxidation of $\mathrm{CH}_{4}$ and faster aerobic decomposition, which results in increased $\mathrm{CO}_{2}$ emissions (Clymo 1983).

Compaction has an effect on soil bulk density and soil depth. Increased compaction can have a significant impact on the hydrological properties of the soil, such as infiltration rates, hydraulic conductivity, and soil pore size (Holden et al. 2005). Therefore, changes in hydrological properties would eventually impact the magnitude of the carbon emissions, as the hydrological properties govern the water table depth (Holden et al. 2004; Groot 1998).

In peatlands, vegetation, soil temperature, and soil moisture content are the primary factors influencing rates of carbon sequestration and emissions (Holden et al. 2005; Bubier et al. 2003; Bubier 1998; Oechel et al. 1995). Wetland carbon emissions are highly susceptible to small changes in soil moisture and surface temperature (Aurela et al. 
2001; Alm et al. 1999; Joiner et al. 1999; Shurpali et al. 1995). Drought or changes in water table depth have an effect on both soil respiration and photosynthesis (Alm et al. 1999). Currently, it is not clear whether changes in water table depth impacts photosynthesis more so than respiration. Lafleur et al. (2003) and Shurpali et al. (1995) show that changes in water table depth have more of an effect on photosynthesis than on respiration. However, Alm et al. (1999), Aurela et al. (2007) and Bubier et al. (2003) show the contrary. Under aerated conditions, the decomposition of organic carbon increases, which results in greater $\mathrm{CO}_{2}$ emissions (Frolking et al. 2001; Whiting and Chanton 2001; Scanlon and Moore 2000). In contrast, vegetation growth may increase with a greater root aeration zone. Laine and Minkkinen (1996) showed that drained peatlands with no tree harvesting are more likely to have increased carbon sequestration rates. However, under standardized harvesting process, the accumulation of carbon was not changed during the peatlands drainage. Under lower water table depth, root production and litter will increase by the trees in peatland; consequently sustained lower soil moisture can increase the production rate. However, this may not apply to peatlands that have limited or no trees (Alm et al. 1999). In the Sphagnum dominated fens, drought is observed to have a negative impact on the plant productivity. Shurpali et al. (1995) and Joiner et al. (1999) both observed that during drought Sphagnum dominated fens acted as a net source of $\mathrm{CO}_{2}$ when compared with years with higher rainfall. However, timing and extend of the drought played an important role in determining the total $\mathrm{CO}_{2}$ loss. Drought is observed to have impact on both photosynthesis and respiration, but at present it is not clear which one is affected more (Lafleur 2009). 
Temperature plays a strong role in determining NEE, as both photosynthesis and respiration of peatlands are strongly influenced by temperature (Chapman and Thurlow 1996; Silvola et al. 1996). Warmer temperatures increase plant growth, evapotranspiration and the zone of aeration for roots, resulting in higher photosynthetic activity unless peatlands are stressed due to drought. Meanwhile, respiration rates double with every $10^{\circ} \mathrm{C}$ increase in the soil temperature (Holden et al. 2005; Blodau 2002). This occurs as microbial community activity increases under warmer conditions. A study by Groendahl et al. (2007) showed that temperature promotes photosynthesis to a greater extent than respiration, suggesting that increases in temperature will likely make peatlands a better carbon sink.

The third important control on carbon sequestration and emissions is vegetation. In majority of the literature, vegetation abundance is often expressed using leaf area index (LAI), which is defined as the $\mathrm{m}^{2}$ of the leaf per $\mathrm{m}^{2}$ of the ground. NEE is observed to be dependent on the LAI (Lafleur 2009). In comparison to bryophytes, vascular plants have greater loss of $\mathrm{CO}_{2}$ during the process of gas exchange as they have greater surface area, and stomata (Campbell and Williamson 1997; Price and Waddington 2000). The root system of vascular plants allows them to have better access to areas of peak microbial activity, hence providing the pathway for emissions through aerenchyma tissue. Vascular plants have greater LAI than bryophytes, which allows them to sequester more atmospheric carbon during the processes of photosynthesis.

Strack et al. (2008) showed that a decrease in water table depth can result in a shift in plant communities. When the water table was lowered, it was observed that Sphagnum increased in the hollows in comparison to a control site; sedges increased in 
the lawns. Shurpali et al. (1995) and Joiner et al. (1999) noticed that during a dry year, peatlands acted as a source of carbon due to increased oxidation and enhanced aerobic decomposition. Bubier et al. (2003) observed that a water table decrease of $10 \mathrm{~cm}$ resulted in a $47 \%$ increase in total respiration. Silvola el al. (1996) predicted that respiration will increase by almost $50-100 \%$ if the water table depth was decreased by $14-$ $22 \mathrm{~cm}$. However, laboratory experiments showed a 12-20 times increase in respiration under oxic conditions, relative to anoxic conditions (Moore and Dalva 2001; Bubier et al. 2003). Aerobic conditions enhance the activity of the enzyme known as phenol oxidase, which is used in degrading the recalcitrant phenolic compounds in the soil; hence, during lower water table depths, there is an increase in respiration (Christensen et al. 1998; Moore and Dalva 1993).

Bubier et al. (2003) classified the increase in respiration based on vegetation type under lower water table depth. During a dry summer, respiration increased $53-84 \%$ for evergreen shrub vegetation, $36-48 \%$ for sedges, and $13 \%$ for deciduous shrubs. Some studies showed that poor fens, which are dominated by sedges, sequester greater amounts of $\mathrm{CO}_{2}$ than shrub bogs or deciduous shrub-rich fens, due to the dominance of photosynthesis over respiration when water tables are lower (Bubier et al. 2003; Bellisario et al. 1998). Bubier et al. (2003) identified that the photosynthetic capacity of sedges was greater than that of deciduous shrubs and evergreen shrubs. Busch and Losch (1999) showed that under fluctuating moisture conditions, distinct species react uniquely. For instance, a fen dominated by sedges, located in Mer Bleue and Manitoba, showed decreased uptake of $\mathrm{CO}_{2}$ during the drier years (Lafleur et al. 2001; Joiner et al. 1999). In another study, during a drier year, a fen located in Churchill Manitoba transitioned from a 
carbon-sink to a carbon-source as a result of decrease in sedge photosynthesis; particularly due to lack of plant development in response to decrease in soil moisture content (Griffis et al. 2000). Alm et al. (1999) showed that under decreased or limited soil moisture conditions, desiccation of moss occurs, resulting in decreased photosynthesis. Weltzin et al. (2000) manipulated the water table in both fen and bog peatlands located in northeastern Minnesota to assess the importance of moisture content on the success of different vegetation types. It was found that both bryophytes and sedges favor higher levels of soil moisture, whereas shrubs do well under reduced soil moisture, which was also observed by Bubier et al. (2003). During a drier period, Bubier et al. (2003) noticed a transition from sedges to shrubs under decreased soil moisture content. Therefore, lower water tables and a greater aerobic zone in the peat may act to increase total respiration while depending on the type of vegetation; this can either have a positive or negative effect on plant productivity.

\subsubsection{Controls on methane flux}

Previous studies showed that $\mathrm{CH}_{4}$ emissions are dependent on water table depths, soil temperature and LAI (Christensen et al. 2003; Bubier et al. 1995; Moore and Dalva 1993). Changes in water table depth and peat temperature were the main determinant of $\mathrm{CH}_{4}$ emissions in a study by Christensen et al. (2003); whereas Bubier et al. (2005) suggested substrate availability and water table depth were the main determinants. Changes in water table depth are typically well correlated to $\mathrm{CH}_{4}$ fluxes. Abundant soil moisture creates anaerobic conditions, which activates methaneogenesis bacteria, resulting in $\mathrm{CH}_{4}$ production. Higher water table depth was observed to be synonymous with increase in $\mathrm{CH}_{4}$ emissions (Aerts and Ludwig 1997; Bubier 1995; Dise et al. 1993). 
Drier sites were observed to have lower $\mathrm{CH}_{4}$ fluxes than wetter sites (Strack et al. 2008). Water drawdown yields lower $\mathrm{CH}_{4}$ emissions due to decreased methaenogenesis. Bubier et al. (2005) observed a log linear relationship between water table depth and $\mathrm{CH}_{4}$ emissions. The $\mathrm{CH}_{4}$ emissions increased by almost $60 \%$, when water table depth increased by $2-5 \mathrm{~cm}$ (Bubier et al. 2005). Strack et al. (2004) showed that at a drained site, $\mathrm{CH}_{4}$ emissions were observed to be $55 \%$ lower than that of the control site, since the anoxic zone was decreased significantly by the removal of standing water. Increase in $\mathrm{CH}_{4}$ emissions can be attributed to an increase in peat temperature as well as an increase in water table depth (Bubier et al. 2005). However, some studies reported opposing trends as they noted higher $\mathrm{CH}_{4}$ flux with a lower water table depth (Bellisario et al. 1999; Kettunen et al. 1996). The release of the stored $\mathrm{CH}_{4}$ can be triggered, via bubble release process, when a sudden decrease in hydrostatic pressure is noticed as a result of a decline in the water table depth (Glaser et al. 2004; Rosenberry et al. 2003). Treat et al. (2007) observed greater $\mathrm{CH}_{4}$ emissions during periods with high peat temperature and decreased water table depth. Increase of peat temperature increases the activity of the $\mathrm{CH}_{4}$ producing bacteria thereby increasing the $\mathrm{CH}_{4}$ emissions (Treat et al. 2007). However, if the soil moisture decreases below the threshold level then the $\mathrm{CH}_{4}$ production can stop, as it inhibits the methanogenic-activity (Treat et al. 2007).

A relationship between plant productivity and increase in $\mathrm{CH}_{4}$ emissions has been reported (Treat et al. 2007; King et al. 2002; Joabsson et al. 1999). Increase in plant productivity results in more root exudates, and an enhancement in substrate availability increases $\mathrm{CH}_{4}$ production. The increase in vascular plant biomass resulted in an increase in $\mathrm{CH}_{4}$ emissions at various wetlands (Christensen et al. 2003; Bellisario et al. 1999; 
King et al. 1998). Generally, vascular plants provide more substrate for methanogenic organisms. The roots of vascular plants, which extend into the anoxic zone where $\mathrm{CH}_{4}$ concentrations are high also provide a pathway for $\mathrm{CH}_{4}$ emissions into the atmosphere through air spaces in the stem known as aerenchyma tissues (Strack et al. 2008; Bellisario et al. 1999; Waddington et al. 1996). Carex dominated sites are observed to have greater $\mathrm{CH}_{4}$ emissions than sites dominated by trees and shrubs (Bubier et al. 2005). The increase in sedges biomass, along with an increase in water table depth, caused $\mathrm{CH}_{4}$ emission to increase from $15 \%$ to $90 \%$ between two growing seasons (Bubier et al. 2005). Isotopic analysis of Carex dominated sites shows that bacteria break down newly plant exudates to produce $\mathrm{CH}_{4}$ emissions (Bellisario et al. 1999; Dove et al. 1999; Chanton et al. 1992). Bubier et al. (2005) observed that sedges produce greater biomass during wetter years, which further increases the coverage of aerenchyma tissues and root exudates. Hence, an increase in sedge biomass results in higher $\mathrm{CH}_{4}$ productions and emissions, especially during wet periods (Strom et al. 2003; King et al. 2002; Bellisario et al. 1999).

\subsection{Impact of peat harvesting and drainage on the carbon budget}

About $50 \%$ of the global wetlands have been disturbed over the last few centuries (IUCN 2000). The disturbance is mainly caused by an increase in agricultural practices, pollution, forestry practices, and urbanization (IUCN 2000). According to Jeglum (1990) and Keys (1992), approximately 2500 ha of peatlands have been drained in Canada for forestry and approximately 16000 ha for agriculture. The disturbances impact peatlands' functioning by affecting hydrology, plant communities, and biogeochemical cycles. Disturbances can be categorized in many forms such as water table drawdown, peat 
harvesting, and agricultural practices. This section will concentrate on the impacts of peat harvesting and drainage on net $\mathrm{CO}_{2}$ emissions.

Peatlands are typically drained by lowering the water table using drainage ditches. The decrease in water table creates oxic conditions, which trigger organic matter decomposition (Waddington et al. 2002; Waddington and Price 2000; Sundh et al. 2000). Furthermore, drainage ditches themselves are anoxic zones, where saturated conditions and availability of labile carbon increase $\mathrm{CH}_{4}$ production (Waddington and Day 2007; Sundh et al. 2000). Silvola (1986) observed that a decrease in the water table depth of natural peatlands, from $10 \mathrm{~cm}$ to $60 \mathrm{~cm}$ below the surface, increased the emissions of $\mathrm{CO}_{2}$ by $270-300 \%$. Following the peat drainage, the surface vegetation is removed and upper peat layers are crushed, using machinery, to further reduce moisture content of the peat (Cleary 2005; Strack et al. 2003). According to Waddington and Warner (2001), the $\mathrm{CO}_{2}$ emissions can increase by almost $100 \%-400 \%$, and can exist up to 20 years after the peat extraction. This is due to an increase in peat oxidation and a lack of carbon fixing vegetation. During the harvesting process, peatlands are highly susceptible to temperature, oxygen availability and lower soil moisture content. According to Ahlholm and Silvola (1990), the $\mathrm{CO}_{2}$ emissions can be up to $3 \mathrm{~g} \mathrm{~m}^{-2} \mathrm{hr}^{-1}$ from left over peat piles. The harvesting process results in changes in soil structure and may cause peat subsidence, which further affects the pore size, water storage capacity and hydraulic conductivity of the peatlands creating unsuitable conditions for re-colonization of Sphagnum (Price et al. 2003; Price and Whitehead 2001; Bugnon et al. 1997; Ferland and Rochefort 1997).

Waddington et al. (2009) reported $\mathrm{CO}_{2}$ and $\mathrm{CH}_{4}$ emissions from three natural sites (Cagampan and Waddington 2008; Roulet et al. 2007; and Gorham 1991). The emissions 
from these natural peatlands were used as baseline data to compare to the disturbed peatlands. The annual $\mathrm{CO}_{2}$ emissions from these natural sites ranged from -37.6 to $25.5 \mathrm{t}$

$\mathrm{CO}_{2} 75 \mathrm{ha}^{-1} \mathrm{y}^{-1}$. In comparison, $\mathrm{CO}_{2}$ emissions from the disturbed peatlands were 3 orders of magnitude greater at approximately $8400 \mathrm{t} \mathrm{CO}_{2} 75 \mathrm{ha}^{-1} \mathrm{y}^{-1}$. In future it would be extremely difficult to bring these peatlands to their original state if until disturbance is reduced considerably.

\subsection{Important reclamation parameters and techniques used in the literature}

Many structural changes occur during the peat extraction processes. The peat drainage results in subsidence, and well as enhanced peat oxidation. In many previous studies vegetation, soil moisture and soil temperature was observed to be the essential parameter in reclamation process (Waddington and Warner 2001). The primary goal of the reclamation strategy is to maintain essential soil moisture level for the newly planted vegetation. Also introduction of Sphagnum at the disturbed peat surface helps in retain the soil moisture, which is required for the vegetation survival. Many techniques had been implemented in the past such as continuous rewetting of the soil or transplantation of acrotelm layer from natural peatland to the disturbed sites. The transplanted acrotelm retains sufficient soil moisture and allows plants to survive, especially during drought periods. The soil temperature can either have a positive or negative impact on the success of the reclamation as it governs the evapotranspiration and production rate (Lafleur 2009; Cagampan and Waddington 2008; Waddington and Warner 2001). In Cagampan (2008) the acrotelm layer was transplanted directly on the top of the cutover peatland. The introduction of the acrotelm layer resulted in reduced respiration rates by maintaining the soil moisture conditions, which were observed to be quite similar as the natural site. 
Waddington and Warner (2001) also showed an increase in photosynthesis was almost two-fold greater than natural peatland as re-introduction of Sphagnum sustained sufficient soil moisture during the growing season. Similar results were observed by Waddington et al. (2010) where re-introduction of vegetation resulted in higher soil moisture and photosynthesis during the growing period. Therefore, following examples establishes the dependency of successful reclamation on vegetation, soil moisture, and soil temperature. 


\subsection{Methods}

\subsection{Site description}

The study site is located on the Syncrude Canada Ltd mine site near the south end of the Mildred Lake basin, Fort McMurray, Alberta, Canada $\left(57^{0} 39^{\prime} \mathrm{N}, 111^{\circ} 13^{\prime} \mathrm{W}\right)$. The transplanted cells, approximately $20 \mathrm{~m} \times 10 \mathrm{~m}$ in area, were placed in twenty-eight adjacent sites (Figure 3.1).

The climate at the site is characterized by cold winters and warm summers, and is categorized as sub-humid continental climate. The average temperatures for January and July are $-18.8^{\circ} \mathrm{C}$ and $16.8{ }^{\circ} \mathrm{C}$, respectively, for Fort McMurray, Alberta (Environment Canada 2007). The mean annual precipitation is $455 \mathrm{~mm}$, of which $75 \%$ occurs as rain and $25 \%$ as snow. Rainfall usually occurs as a short, high intensity storm and is quite frequent between the months of June and August, as nearly 67\% of the annual rainfall occurs during this period (Carey 2008).

\section{2 Experimental Design and Data Collection}

\subsubsection{Experimental Design}

Twenty-eight experimental cells were located adjacent to the south end of the Mildred Lake settling basin. These experimental cells are referred as 'U-shaped cells' as combination of 28 cells looks like the alphabet ' $U$ ' (Figure 3.2). Each experimental cell was separated from the other by $7 \mathrm{~m}$ and filled with a treatment material. Each block was subjected to a different combination of treatments including: 1) peat mix (stockpiled) vs live peat treatments vs. mineral soil treatments, 2) mine water (high in salt content) vs fresh water, 3) compaction vs no compaction, and 4) peat thickness $(15,50,100 \mathrm{~cm})$. For 
example, the first cell comprised $100 \mathrm{~cm}$ thick peat mix and was treated with mine water with no compaction (See Table 3.1 and Figures 3.1 and 3.2 for treatments strategy).

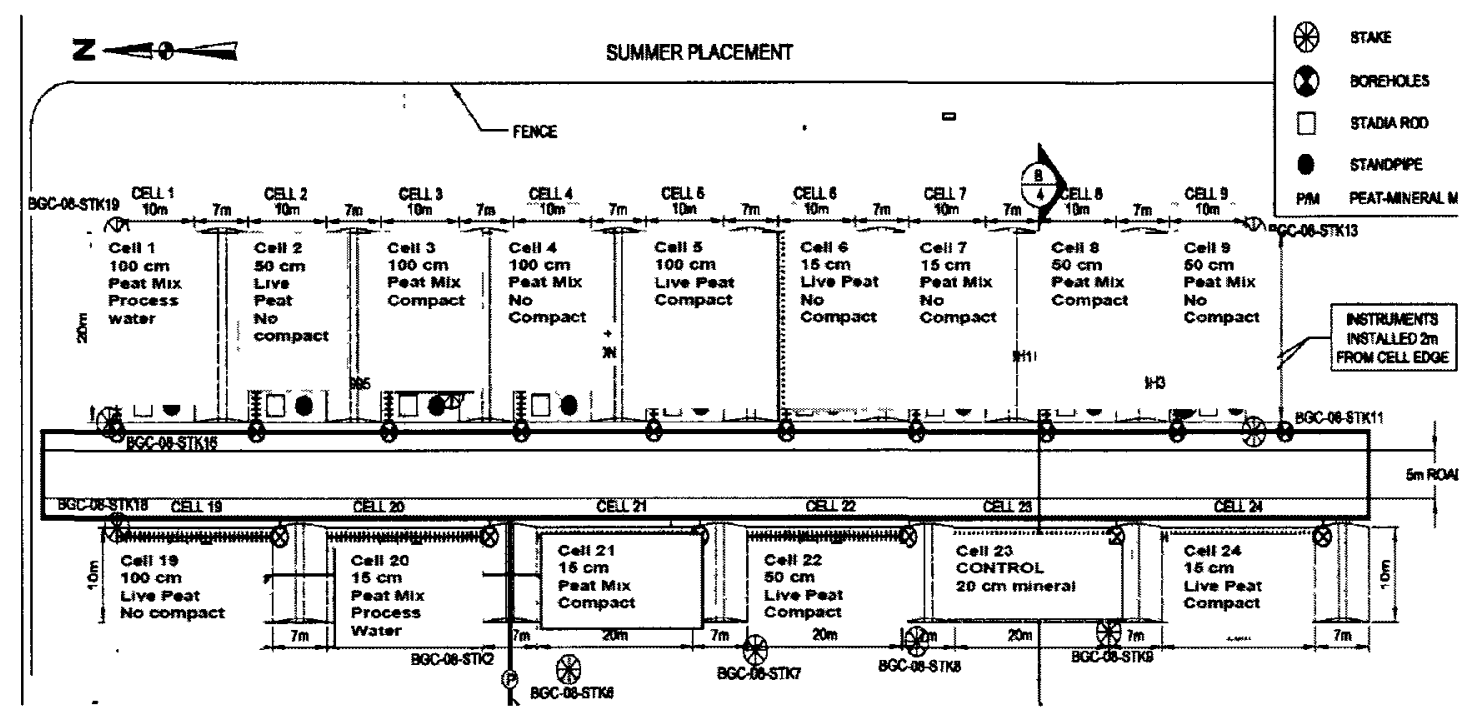

(1) Stockpiled vrs. Live Peat

(3) Compaction yrs. No compaction

(2) Processed water vrs. Freshwater

(4) Placement thickness $(15,50,100 \mathrm{~cm})$

Figure 3.1: Summer treatments placement strategies with block dimensions and treatments

The live peat with intact vegetation was removed from the source drained peatland located within $5 \mathrm{~km}$ of the site at specific thickness $(15 \mathrm{~cm}, 50 \mathrm{~cm}$, and $100 \mathrm{~cm})$ using special machinery. The drained source peatland was referred as a 'natural site' in this thesis. However, in reality it does not have same properties as a natural boreal peatlands since it was drained about 30 years ago and had altered soil properties such as water holding capacity, drainage properties, and soil particle size.

The live peat treatments were removed in $3 \times 3 \mathrm{~m}$ blocks from the drained natural site during summer of 2008 and winter of 2008 . They were then placed in the truck and 
were transported to the U-shaped site. The live summer and winter treatments were then transplanted into the U-shaped cells and the space between blocks was filled with peat mix, which is simply stored peat mixture extracted during previous mining activities. For some treatments stored stockpiled peat mix soil was used, and there was no vegetation (Table 3.1). The peat mix soil was stored for at least five years before it was transplanted to U-shaped cells. However, information on how peat mix soils were stored and maintained was not available. At the start of the growing season, green house vegetation was planted in the peat mix treatments. There was no particular strategy for the plantation in the peat mix treatments. The full detail about the type of vegetation in each treatment is presented in Table 3.1. The green house vegetation was also planted in the live treatments, however, it was insured that no green house vegetation was planted inside the collars of the live treatments. For some cells, the peat material below the peat mix, live, or mineral soil layer was compacted by pressing the soil surface with heavy machinery (Table 3.1). Cell 1 and cell 20 were watered with mine water (high salt concentration). A truck used to bring the mine water. Fresh water was used for all remaining cells (Table 3.2 and Figure 3.2). The watering of the treatments at the U-shaped cells was done about every 2-3 days or when ever there was a need on the basis of water table depth. The fresh water used to be pumped from the pond, which was situated adjacent to the U-shaped cells. However, the amount of water going into the treatments was not measured. The transplanted cells were not maintained until the start of the growing season of 2009 as no watering took placed until the start of the growing season. No watering was done at the natural site at any point, and it was completely dependent on the rainfall events to recharge its soil moisture. The cells that were placed into the U-shaped site during the 
summer of 2008 are called summer treatments and the ones which were transplanted during winter of 2008 are called winter treatments (Figure 3.2). It was important to know which of these seasonal transplants will adapt better at the U-shaped cells.

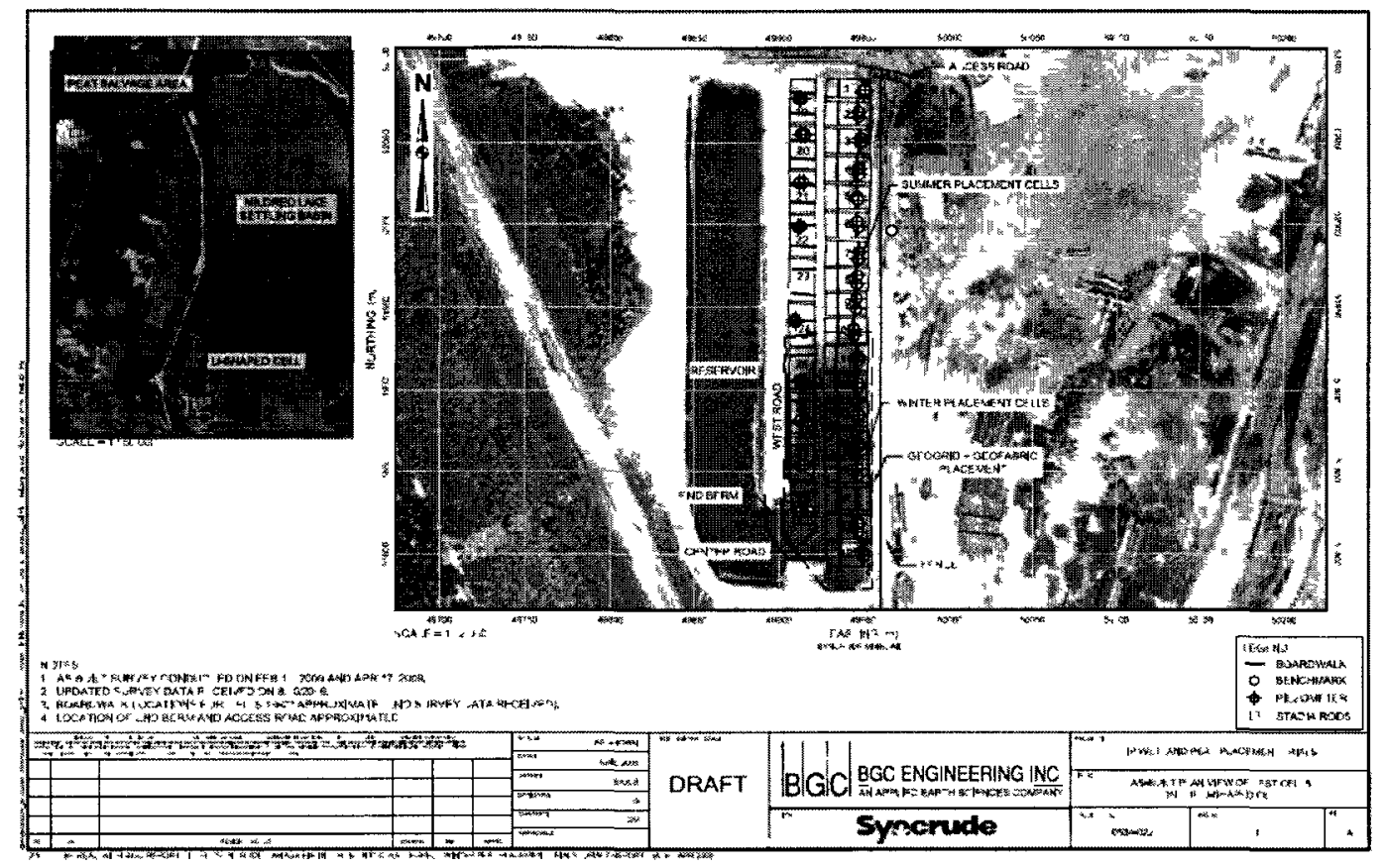

Figure 3.2: A view of complete U-shaped cell treatments view and the Mildred Lake settling basin and natural sites 
Table 3.1: Details of the treatments of each treatment at a U-shaped site during the growing season of 2009 .

\begin{tabular}{|c|c|c|c|c|c|c|}
\hline Cell Number & Treatment & $\begin{array}{l}\text { Soil } \\
\text { Thickness } \\
\text { (cm) }\end{array}$ & $\begin{array}{l}\text { Treatments } \\
\text { type }\end{array}$ & $\begin{array}{l}\text { Type of } \\
\text { water used }\end{array}$ & Compaction & Plant species \\
\hline 1 (P_100_s_pw) & Peat Mix & 100 & Summer & Mine water & No & $\begin{array}{l}\text { Equisetum } \\
\text { scirpoides, } \\
\text { Betula } \\
\text { glandulifera, } \\
\text { Triglochin } \\
\text { maritime, } \\
\text { Salix spp }\end{array}$ \\
\hline 2 (L_50_s) & Live peat & 50 & Summer & Fresh Water & No & $\begin{array}{l}\text { Vaccinium } \\
\text { spp,Cladina } \\
\text { spp, } \\
\text { Vaccinium } \\
\text { vitis-idaea, } \\
\text { Betula } \\
\text { glandulifera, } \\
\text { Picae marina, } \\
\text { Carex spp }\end{array}$ \\
\hline $3\left(P_{-} 100 \_s \_c\right)$ & Peat Mix & 100 & Summer & Fresh Water & Yes & $\begin{array}{l}\text { Betula } \\
\text { glandulifera, } \\
\text { Carex spp }\end{array}$ \\
\hline $4\left(P_{-}\right.$100_s $)$ & Peat Mix & 100 & Summer & Fresh Water & No & Salix spp \\
\hline 5 (L_100_s_c) & Live peat & 100 & Summer & Fresh Water & Yes & $\begin{array}{l}\text { Larix } \\
\text { laricina, } \\
\text { Vaccinium } \\
\text { spp,Cladina } \\
\text { spp, Picae } \\
\text { marina, } \\
\text { Vaccinium } \\
\text { vitis-idaea }\end{array}$ \\
\hline 6 (L_15_s) & Live peat & 15 & Summer & Fresh Water & No & $\begin{array}{l}\text { Carex spp, } \\
\text { Bryopsida spp, } \\
\text { Vaccinium } \\
\text { vitis-idaea, } \\
\text { Vaccinium } \\
\text { spp,Cladina } \\
\text { spp }\end{array}$ \\
\hline 7 (P_15_s) & Peat Mix & 15 & Summer & Fresh Water & No & $\begin{array}{l}\text { Larix laricina, } \\
\text { Salix spp }\end{array}$ \\
\hline $8\left(\mathrm{P} \_50 \_s \_c\right)$ & Peat Mix & 50 & Summer & Fresh Water & Yes & $\begin{array}{l}\text { Betula } \\
\text { glandulifera, } \\
\text { Carex spp }\end{array}$ \\
\hline 9 (P_50_s) & Peat Mix & 50 & Summer & Fresh Water & No & $\begin{array}{l}\text { Carex spp, } \\
\text { Equisetum } \\
\text { scirpoides }\end{array}$ \\
\hline $10\left(P_{-} 100 \_w\right)$ & Peat Mix & 100 & Winter & Fresh Water & No & $\begin{array}{l}\text { Betula } \\
\text { glandulifera, }\end{array}$ \\
\hline
\end{tabular}




\begin{tabular}{|c|c|c|c|c|c|c|}
\hline & & & & & & Carex spp \\
\hline $11\left(\mathrm{~L} \_15 \_w\right)$ & Live peat & 15 & Winter & Fresh Water & No & $\begin{array}{l}\text { Vaccinium } \\
\text { vitis-idaea, } \\
\text { Vaccinium } \\
\text { spp, Carex } \\
\text { spp, Bryopsida } \\
\text { spp, } \\
\text { Rhododendron } \\
\text { groenlandicum } \\
\text {, Larix laricina }\end{array}$ \\
\hline 12 (L_100_w) & Live peat & 100 & Winter & Fresh Water & No & $\begin{array}{l}\text { Picae marina, } \\
\text { Larix laricina, } \\
\text { Bryopsida spp, } \\
\text { Vaccinium } \\
\text { spp, } \\
\text { Vaccinium } \\
\text { vitis-idaea, } \\
\text { Cladina spp }\end{array}$ \\
\hline 13(P_100_w_c) & Peat Mix & 100 & Winter & Fresh Water & Yes & $\begin{array}{l}\text { Carex spp, } \\
\text { Larix laricina, }\end{array}$ \\
\hline 14 (P_50_w_c) & Peat Mix & 50 & Winter & Fresh Water & Yes & $\begin{array}{l}\text { Carex spp } \\
\text { Larix laricina }\end{array}$ \\
\hline $15\left(\mathrm{~L} \_15 \_w \_c\right)$ & Live peat & 15 & Winter & Fresh Water & Yes & $\begin{array}{l}\text { Larix laricina, } \\
\text { Bryopsida spp, } \\
\text { Vaccinium } \\
\text { spp, } \\
\text { Vaccinium } \\
\text { vitis-idaea, } \\
\text { Cladina spp, } \\
\text { Equisetum } \\
\text { scirpoides }\end{array}$ \\
\hline 16 (M_20_w) & Mineral Soil & 20 & Winter & Fresh Water & N/A & $\begin{array}{l}\text { Carex spp, } \\
\text { Betula } \\
\text { glandulifera }\end{array}$ \\
\hline 17 (P_50_w) & Peat Mix & 50 & Winter & Fresh Water & No & $\begin{array}{l}\text { Carex spp, } \\
\text { Betula } \\
\text { glandulifera }\end{array}$ \\
\hline $18\left(\mathrm{~L} \_50 \_w\right)$ & Live peat & 50 & Winter & Fresh Water & No & $\begin{array}{l}\text { Bryopsida spp, } \\
\text { Vaccinium } \\
\text { spp, Cladina } \\
\text { spp, } \\
\text { Equisetum } \\
\text { scirpoides }\end{array}$ \\
\hline 19 (L_100_s) & Live peat & 100 & Summer & Fresh Water & No & $\begin{array}{l}\text { Vaccinium } \\
\text { vitis-idaea, } \\
\text { Vaccinium } \\
\text { spp, Cladina } \\
\text { spp, , Carex } \\
\text { spp, Picae } \\
\text { marina, } \\
\text { Rhododendron } \\
\text { groenlandicum }\end{array}$ \\
\hline
\end{tabular}




\begin{tabular}{|c|c|c|c|c|c|c|}
\hline $20\left(P_{-} 15 \_s \_p w\right)$ & Peat Mix & 15 & Summer & Mine Water & No & $\begin{array}{l}\text { Potentilla } \\
\text { Palustris, Salix } \\
\text { spp }\end{array}$ \\
\hline $21\left(P \_15 \_s \_c\right)$ & Peat Mix & 15 & Summer & Fresh Water & Yes & $\begin{array}{l}\text { Salix spp, } \\
\text { Betula } \\
\text { glandulifera }\end{array}$ \\
\hline 22 (L_50_s_c) & Live peat & 50 & Summer & Fresh Water & Yes & $\begin{array}{l}\text { Vaccinium } \\
\text { vitis-idaea, } \\
\text { Vaccinium } \\
\text { spp, Cladina } \\
\text { spp, Picae } \\
\text { marina, } \\
\text { Rhododendron } \\
\text { groenlandicum } \\
\text { Betula } \\
\text { glandulifera }\end{array}$ \\
\hline 23 (M_20_s) & Mineral Soil & 20 & Summer & Fresh Water & N/A & Larix laricina \\
\hline $24\left(\mathrm{~L} \_15 \_s \_c\right)$ & Live peat & 15 & Summer & Fresh Water & Yes & $\begin{array}{l}\text { Vaccinium } \\
\text { vitis-idaea, } \\
\text { Rhododendron } \\
\text { groenlandicum } \\
\text {, Bryopsida } \\
\text { spp, Cladina } \\
\text { spp }\end{array}$ \\
\hline $25\left(P_{-} 15 \_w \_c\right)$ & Peat Mix & 15 & Winter & Fresh Water & Yes & $\begin{array}{l}\text { Betula } \\
\text { glandulifera, } \\
\text { Salix spp }\end{array}$ \\
\hline $26($ L_50_w_c) & Live peat & 50 & Winter & Fresh Water & Yes & $\begin{array}{l}\text { Vaccinium } \\
\text { vitis-idaea, } \\
\text { Vaccinium } \\
\text { spp, Cladina } \\
\text { spp, } \\
\text { Rhododendron } \\
\text { groenlandicum } \\
\text {, Bryopsida } \\
\text { spp, Larix } \\
\text { laricina }\end{array}$ \\
\hline $\begin{array}{l}27 \\
(\text { L_100_w_c })\end{array}$ & Live peat & 100 & Winter & Fresh Water & Yes & $\begin{array}{l}\text { Larix laricina, } \\
\text { Cladina spp, } \\
\text { Vaccinium } \\
\text { vitis-idaea, } \\
\text { Rhododendron } \\
\text { groenlandicum }\end{array}$ \\
\hline $28\left(P_{-} 15 \_w\right)$ & Peat Mix & $15 \mathrm{~cm}$ & Winter & Fresh Water & No & $\begin{array}{l}\text { Larix laricina, } \\
\text { Carex spp, } \\
\text { Equisetum } \\
\text { scirpoides }\end{array}$ \\
\hline
\end{tabular}


Table 3.2: Images of a selection of cells: live summer treatment, live winter treatment, and peat mix summer treatment

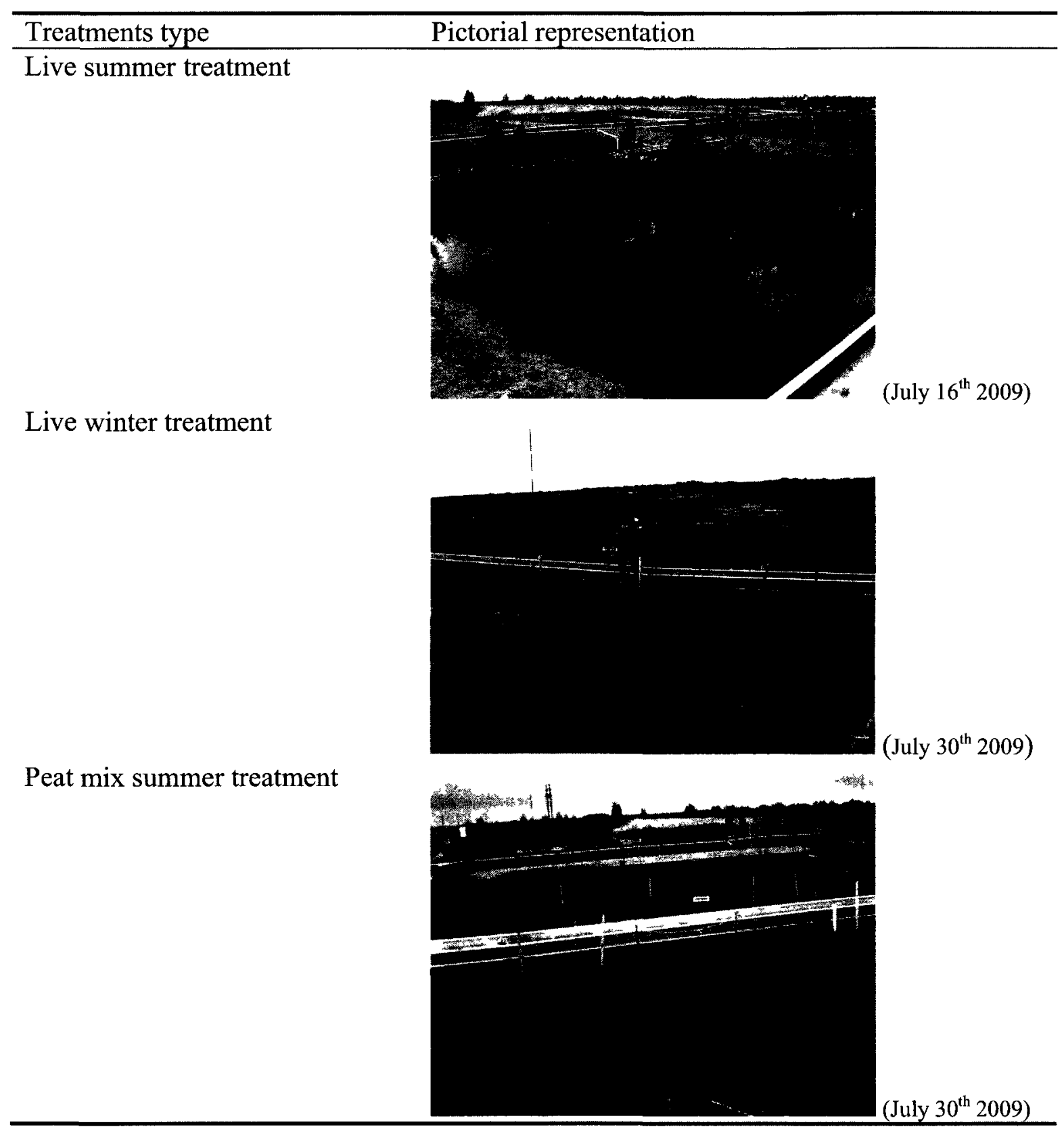


Table 3.3: Images of a selection of cells: peat mix winter treatments, peat mix treatment with mine water, mineral soil treatments, and natural site

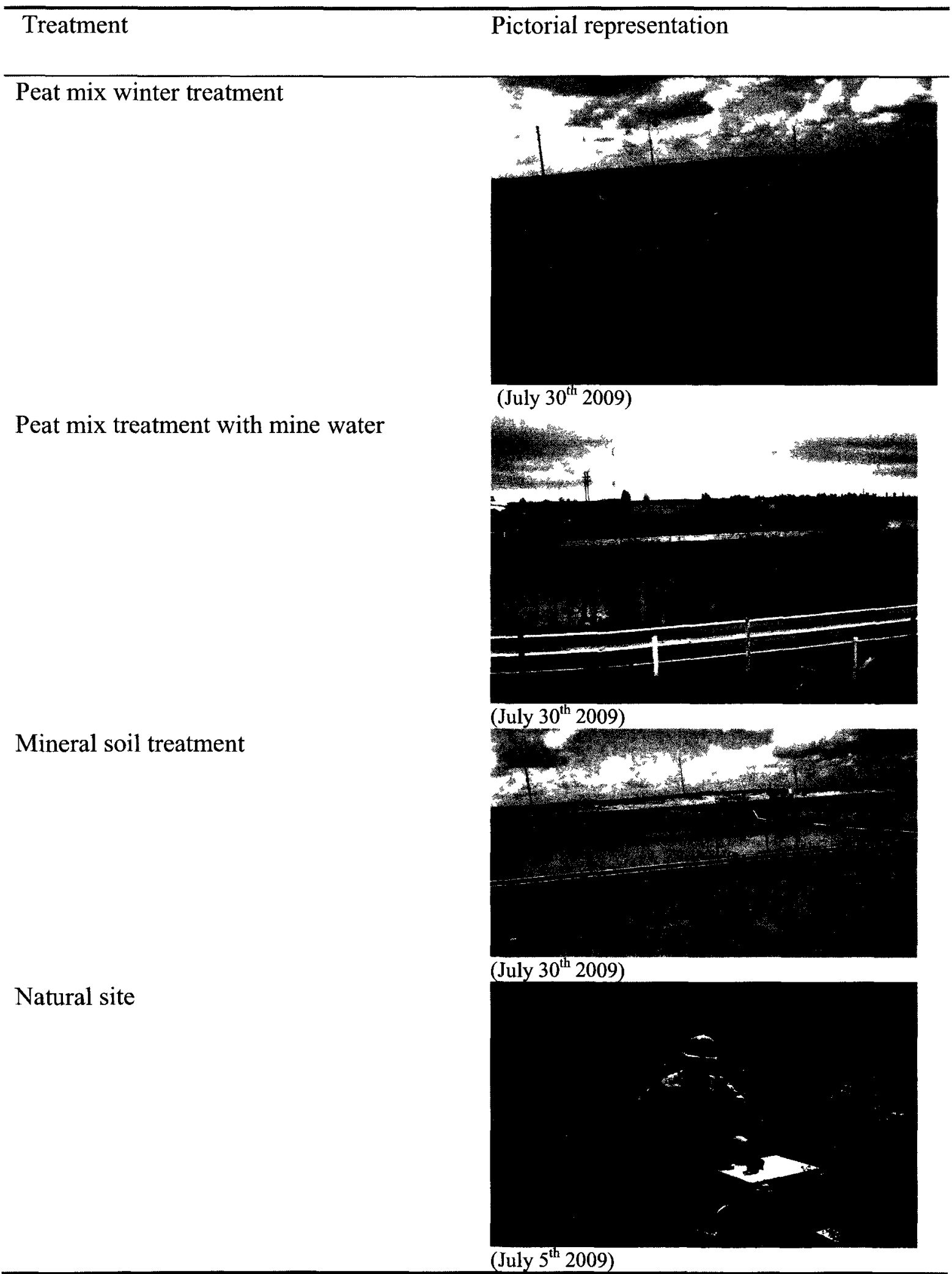




\subsubsection{Data Collection}

The data was collected between 18 May 2009 and 16 August 2009 when weather conditions permitted. In total, measurements were made on 60 days during the growing season.

\subsection{Experimental Techniques}

\subsubsection{Closed Chamber NEE Measurement Technique}

Measurements of NEE and R were made on PVC collars, $15 \mathrm{~cm}$ in height and 30 $\mathrm{cm}$ in diameter, which were inserted $\sim 10-12 \mathrm{~cm}$ into the ground. Two collars were placed in each transplanted cell near the access boardwalks. Four collars were placed in the drained/disturbed natural system that was used as the site from where the live peat treatments were extracted. The collars in the natural site were placed in an area that was easily accessible with minimal local disturbance.

Measurements of NEE were made using a portable, transparent, flow-through, non-steady state chamber system (Figure 3.2). The volume of the acrylic chamber was $0.0197 \mathrm{~m}^{3}$. The chamber was fitted with a mixing fan that circulated air during the measurement and a Peltier cooler and thermocouple to maintain the chamber temperature. The cooler starts automatically when the chamber temperature rises $2{ }^{\circ} \mathrm{C}$ above ambient temperature. The chamber is also fitted with inflow and outflow tubes, which enter through the top of the chamber and connect to a pump, flow meter and LI-840 IRGA (LICOR Inc., Lincoln, Ne, USA) to measure the $\mathrm{CO}_{2}$ and water vapour concentration. Air was circulated through the chamber at $2 \mathrm{~L} \mathrm{~min}^{-1}$ and a subsample of air was passed through the IRGA at the rate of $0.7 \mathrm{~L} \mathrm{~min}^{-1}$. A CR23X data logger (Campbell Scientific) was used to record the data and a $12 \mathrm{~V}$ battery was used to supply power to the 
instrument. These components were housed in a Pelican TM case. A LI-190 quantum sensor (LI-COR Inc.) was mounted on a tripod and used to measure photosynthetic photon flux density (PPFD) (Figure 3.2).

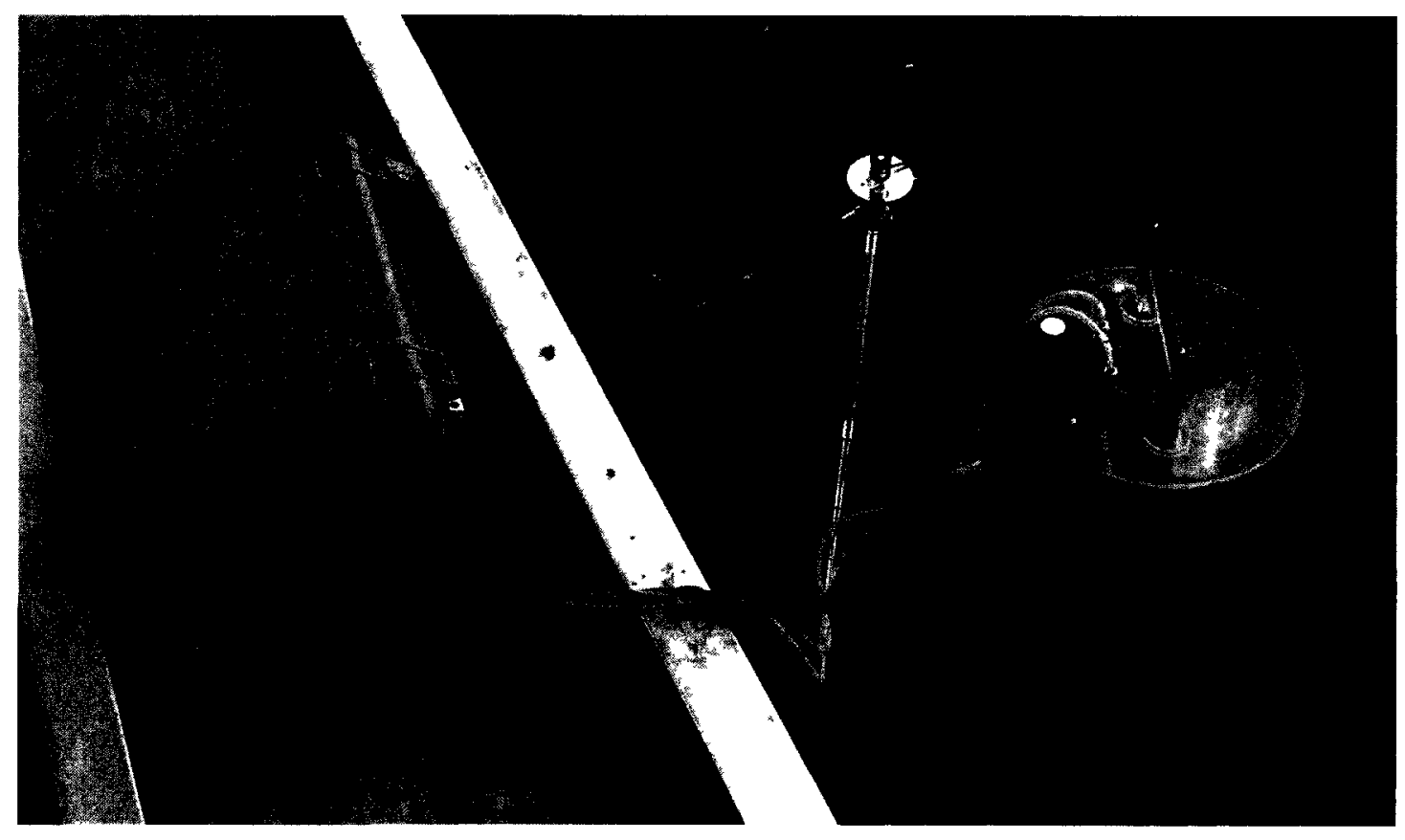

Figure 3.3: The NEE system with acrylic chamber set on a PVC collar and LI-190 quantum sensor on the tripod.

Measurements were made under natural light and varying shade conditions. Before the start of each measurement, the IRGA was allowed to warm up for 10 minutes. Once the IRGA was ready, NEE measurements were made by sealing the chamber to the PVC collar by filling the collar groove with water and recording all variables including $\mathrm{CO}_{2}$ and water vapour mole fractions at $1 \mathrm{~s}$ intervals for 2 minutes. First, NEE was measured under full light (PPFD $\geq 700 \mu \mathrm{mol} \mathrm{m}^{-2} \mathrm{~s}^{-1}$ ), then a second measurement was made with decreased light intensity by placing one shade cloth over the chamber, a third measurement involved 2 layers of shade cloth and the fourth measurement, representing the total respiration from the soil and vegetation, was made by placing an opaque shroud 
(heavy garbage bag) over the chamber. The PPFD sensor was set near the chamber and given the same shroud treatment. Between each measurement, the chamber was equilibrated to ambient conditions by waving it into the wind.

It took approximately 20 minutes to finish a full set of four measurements at different light levels. Each collar was sampled every four or five days. For each collar, 15 NEE measurements were taken during the growing season and it was made sure that measurements were done at random times to avoid bias results. For example, some measurements were made during the morning, while other measurements were done in afternoon or evening.

The relationship between NEE and PPFD can be represented using a rectangular hyperbola equation:

$$
\mathrm{NEE}=\frac{(\mathrm{GEPmax} * \alpha * \mathrm{PAR})}{\left(\mathrm{PAR}^{*} \alpha\right)+\mathrm{GEP} \max }+\mathrm{R}
$$

Where PAR is in $\mu$ mol photons $\mathrm{m}^{-2} \mathrm{~s}^{-1}, \mathrm{GEP}_{\max }$ is the maximum gross ecosystem productivity (asymptote), $\alpha$ is the rate of increase of NEE with increasing PAR (it is also known as apparent quantum yield). The $\mathrm{R}$ is the $\mathrm{y}$-intercept of the equation and equivalent to the average respiration (Bubier et al. 1998).

\subsubsection{Static chamber technique}

A static non-steady state opaque chamber was used to measure the efflux of $\mathrm{CO}_{2}$ and $\mathrm{CH}_{4}$ on the same PVC collars as described above. Before the season started $12 \mathrm{~mL}$ exetainers vials were prepared, in which silicon septa was placed in between plastic lid and rubber stopper. Magnesium perchlorate, a desiccant, was added to each vial, after which the vials were evacuation. The acrylic chamber had a volume of $0.0219 \mathrm{~m}^{3}$ and was covered with a heavy-duty, black garbage bag to block light. From the top of the 
chamber, a single bev-a-line tube was connected to a 3-way stopcock connected to a septa and $60 \mathrm{cc}$ syringe.

During a flux measurement, the chamber was equilibrated with the wind by waving it in the air and then sealed with water to the collar. At 0 min and every 5 min for a total of 5 samples, the $60 \mathrm{cc}$ syringe was pumped 5 times to mix air within the chamber and $30 \mathrm{cc}$ of air were withdrawn using a syringe and needle and $27 \mathrm{cc}$ of this sample was injected into an exetainer (pressure $\sim 2$ atm): During the growing season, six $\mathrm{CH}_{4}$ measurements were conducted for each collar.

\subsubsection{Ancillary measurements}

The rainfall measurements were made using a tipping bucket rain gauge (Texas instruments) which was located within $200 \mathrm{~m}$ of the U-shaped site. At the same location, air temperature was measured at a height of $3 \mathrm{~m}$ above the ground surface, using a HMP45C (Vaisala) attached on the tower.

\subsubsection{Leaf Area Index (pin drop method)}

The Pin Drop method was used to assess LAI (PLAI) as $\mathrm{m}^{2}$ of the leaf/ $\mathrm{m}^{2}$ of the ground surface. PLAI was measured almost every two weeks beginning June $21^{\text {st }}$. A frame strung with fishing line was used to produce 16 intersection points, which were 6 $\mathrm{cm}$ apart from each other (Figure 3.5). The frame was put atop a collar of the same width, and was leveled. A metal pin was dropped straight down to the surface at each intersection point and the number of green leaves that made contact with the pin was recorded by species. The total number of contacts divided by the 16 'drops' was used to calculate vascular LAI within the collar. LAI for each species was then calculated by dividing the total number of contacts for a species divided by the 16 'drops'. Dead and 
non-green leaves were not accounted for in the data even if they were hit by the pin. The mosses and lichens on the surface were, however, recorded if they were hit by the pin. PLAI recorded how vascular and non-vascular vegetation altered during the growing season of 2009.

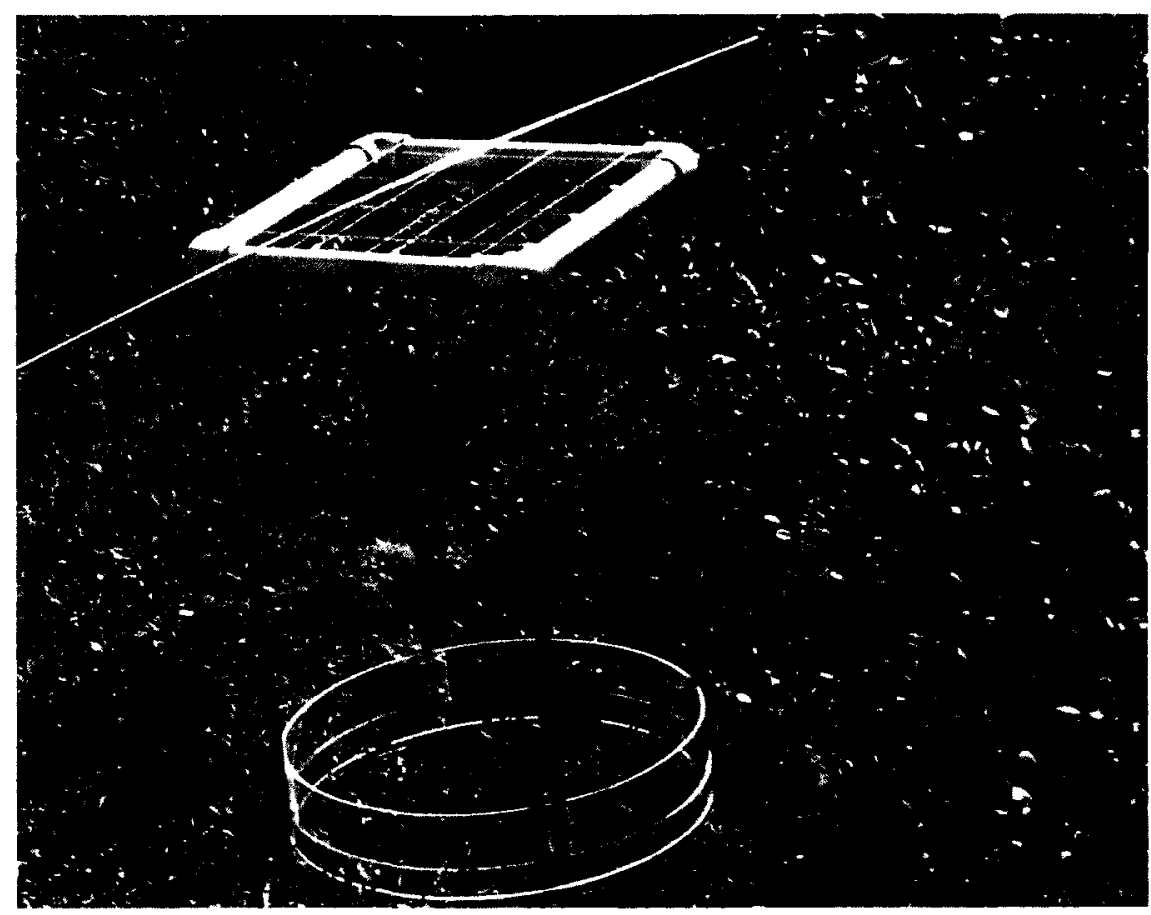

Figure 3.4: The pin drop leaf area index instrument

\subsubsection{Volumetric Water Content and Soil Temperature}

The U-shaped cells were continuously watered beginning the first week of June until the end of the growing season. The volumetric water content (VWC) of the Ushaped cells was measured by Campbell Scientific Hydrosense soil moisture probe, which has a probe length of $20 \mathrm{~cm}$, at the time of $\mathrm{NEE}$ and $\mathrm{CH}_{4}$ flux measurements. During each flux measurement, the soil moisture probe was inserted vertically at five different points near the collar, and the readings were recorded. 
A thermometer with a $10 \mathrm{~cm}$ probe was used to measure the soil temperature during the growing season. During each flux measurement, one reading of the surface temperature and one reading of the soil temperature at a depth of $10 \mathrm{~cm}$ were taken.

\subsection{Data Processing and Analysis}

\subsubsection{Daily and Seasonal NEE, GEP, R Calculations}

The NEE, GEP and $\mathrm{R}$ were pooled together based on the season. The average early, mid, late summer flux was calculated for each treatments type and was expressed as $\mu \mathrm{mol} \mathrm{m} \mathrm{m}^{-2} \mathrm{~s}^{-1}$. The early, mid, late, and full summer average flux was calculated by averaging all the values in each season and then by diving it with the number of days. This gives an approximate flux value during early, mid, and late summer. The full growing season NEE, R, and GEP were obtained by adding total early, mid and late summer season values and these values were reported in $\mu \mathrm{mol} \mathrm{C} \mathrm{m}{ }^{-2}$.

\subsubsection{NEE, R, and GEP Processing and Analysis}

The NEE and $\mathrm{R}$ fluxes were calculated using Matlab 7.4.0 (MathWorks Inc 2007). The NEE and $R$ was calculated for a 2 minute time interval using the following relationship described as:

$$
\mathrm{F}_{\mathrm{CO}_{2}}=\frac{\mathrm{pV}}{\mathrm{R}^{*} \mathrm{~T}_{\mathrm{ch}} \mathrm{A}} \frac{\mathrm{dC}}{\mathrm{dt}} \frac{1}{\left(1+\mathrm{M}_{\mathrm{H}_{2} \mathrm{O}}\right)}
$$

Here, $\mathrm{FCO}_{2}$ is the $\mathrm{CO}_{2}$ flux (either NEE when exposed to light or $\mathrm{R}$ when the chamber was made opaque), $\mathrm{R}^{*}$ is the ideal gas constant, $\mathrm{p}$ is pressure $(\mathrm{Pa}), \mathrm{V}$ is the volume of the chamber $\left(\mathrm{m}^{3}\right), \mathrm{T}_{\mathrm{ch}}$ is the mean air temperature of the chamber $(\mathrm{K}), \mathrm{A}$ is the 
surface area of the chamber $\left(\mathrm{m}^{2}\right)$ and $\mathrm{M}_{\mathrm{H} 2 \mathrm{O}}$ is the water mixing ratio $\left(\mathrm{mol} \mathrm{H}_{2} \mathrm{O} \mathrm{mol}^{-1}\right.$ dry air). $\mathrm{dC} / \mathrm{dt}\left(\mu \mathrm{mol} \mathrm{CO} \mathrm{CO}^{2} \mathrm{~mol}^{-1}\right.$ dry air s $\mathrm{s}^{-1}$ ) represents the rate at which the mixing ratio of $\mathrm{CO}_{2}$ changed inside the chamber during the 2 min measurement period. For some measurements, the data showed inconsistencies in the $\mathrm{dC} / \mathrm{dt}$ usually due to transient cloudy conditions. In those instances, a shorter time interval was used to calculate the NEE flux.

GEP was then computed as R-NEE. Outliers for NEE, R and GEP were removed. The values which were too far from the mean and unrealistic values were categorized as the outliers. For example, negative GEP values were removed as it is not possible to have a negative photosynthesis.

The growing season was divided into three periods based on the air temperature and LAI. The early summer was relatively cold. It started on DOY 138 (May $18^{\text {th }}$ ) and finished on DOY 164 (June $13^{\text {th }}$ ). The mid-summer was warm and had low LAI. This period spanned DOY $165-195$ (June $14^{\text {th }}-$ July $14^{\text {th }}$ ). The late summer was from DOY 196-228 (July $15^{\text {th }}-$ August $16^{\text {th }}$ ). This period was warm and had larger LAI. The data was organized further by treatments type and compaction status (e.g. live summer treatments with compaction vs. live winter treatments with compaction). Once the grouping was completed, the data was entered into JMP 8.0 (Sall et al. 2005) and a oneway analysis of variance (ANOVA) was performed to discern any significant differences between various groupings during three different seasons. When treatment had a significant effect on fluxes, Tukey's HSD was used to determine significant differences among the treatment types. 
In addition to the above analysis, Multivariate ANOVA (MANOVA) analysis was conducted to analyze more than one dependent variable as a function of time. A weekly average of the flux was calculated for NEE, R, and GEP for all treatments types. If the value was missing for a given week, it was calculated by taking the average of previous and subsequent week's values. If the first week's reading was missing for some collars, the subsequent week's average flux value was used as a substitute. This was necessary because an MANOVA analysis cannot be conducted in JMP if there is a missing value in the data set. Once the table was prepared, the MANOVA analysis was conducted to see how fluxes varied or changed during the growing season. The grouping which was used for the MANOVA analysis was based only on the type of treatments, as results from oneway ANOVA showed no significant differences among plots with compaction and without compaction (see section 4.7). Wilks' Lambda was the statistic test which was used for ANOVA and MANOVA analysis (Sall et al. 2005; Mendenhall et al. 1999).

The main assumptions associated with ANOVA and MANOVA are: 1) the data within each population should be normally distributed and must have a common variance, 2) The samples need to be randomly and independently selected from their respective populations (Mendenhall et al. 1999). The data from this study does not conforms the assumptions of ANOVA and MANOVA analysis as normal distribution was not present for each population, and also measurements were dependent of the previous measurements.

According to Mendenhall et al. (1999), when the sample size of two populations is equal and data is normally distributed, the analysis of variance is quite robust. As 
multiple testing was done in this study, the significance level $(\alpha)$ of 0.05 was used and maintained for all the analyses, (Sall et al. 2005; Mendenhall et al. 1999).

\subsubsection{Closed Chamber Methane flux and $\mathrm{CO}_{2}$ Processing and Analyses}

Gas samples were transported to Carleton University where concentrations of $\mathrm{CH}_{4}$ and $\mathrm{CO}_{2}$ were analysed by gas chromatograph (GC) (CP 3800, Varian, 10 CA, USA). The Flame-ionization detector (FID) and GC methanizer were operated at temperatures of $300{ }^{\circ} \mathrm{C}$ and $350^{\circ} \mathrm{C}$ respectively. The flow of the carrier gas, Helium, was $30 \mathrm{ml} \mathrm{min}{ }^{-1}$. Gas separation was carried out by using a Haysep N 80/100 pre-column $(0.32 \mathrm{~cm}$ diam. $\mathrm{x}$ $50 \mathrm{~cm}$ length $)$ and Poropak QS 80/100 mesh analytical columns $(0.32 \mathrm{~cm}$ diam. $\times 200$ cm length). The column oven temperature was maintained at $50^{\circ} \mathrm{C}$.

Along with Helium, five standards, whose concentration ranged from 439.2 and

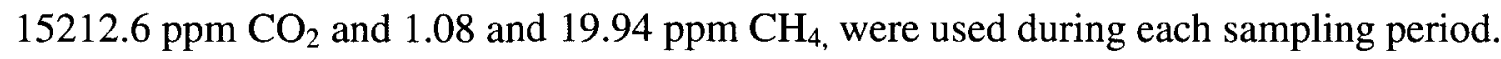
The use of standards ensured quality control, and maintained a linear relationship between chromatogram and gas concentrations. Samples of ambient air were also collected in the field to maintain the reliability of the samples.

All the liquefied samples were rejected, since they indicated that the vial seals were broken during transportation - leading to the modification or loss of original concentrations. $\mathrm{CH}_{4}$ and $\mathrm{CO}_{2}$ mixing ratios were obtained from the $\mathrm{GC}$ and were transferred in the MS excel. The concentrations were corrected by the temperature and pressure. The quality of the fluxes was controlled manually by deleting the outliers from the MS excel sheet. These concentrations were then converted into fluxes in the MS excel by equations 3.3 . 


\subsection{Results}

\subsection{Growing Season Climate}

A total of $114.6 \mathrm{~mm}$ of rainfall was recorded at the study site during the growing season. The driest month was May, with only $4.6 \mathrm{~mm}$ of rain, which is well below the 30 year climate normal of $29.6 \mathrm{~mm}$ (Table 4.1). Dry conditions continued until mid June after which a series of moderate and large rainfall events occurred. The largest precipitation event occurred on 22 June 2009 when $29.7 \mathrm{~mm}$ of rain was recorded (Figure 4.1). Despite this rainfall event, total rainfall for the month of June was $64 \mathrm{~mm}, 10.8 \mathrm{~mm}$ less than the June 30-year climate normal (Table 4.1). Rain was more frequent in July, occurring on 14 days, yet total rainfall was only $27.9 \mathrm{~mm}$, well below the 30 -year climate normal of $81.2 \mathrm{~m}$ (Figure 4.1 and Table 4.1). In comparison to the 30-year climate normal, the U-shaped cells received $114.6 \mathrm{~mm}$ of rain, much less than the $262.8 \mathrm{~mm}$ expected during this period. Environmental Canada's weather station at Fort McMurray recorded greater rainfall $(171.4 \mathrm{~mm})$ than at the research site. However, Environmental Canada data further confirms that 2009 study year was relatively drier than 30 -year climate normal for Fort McMurray (Table 4.1).

The growing season of 2009 was slightly warmer during June and August when compared with the long term Fort McMurray climate normal data (Table 4.1, Figure 4.2). However, during May it was less warm than the climate normal, and in July it was almost the same. 


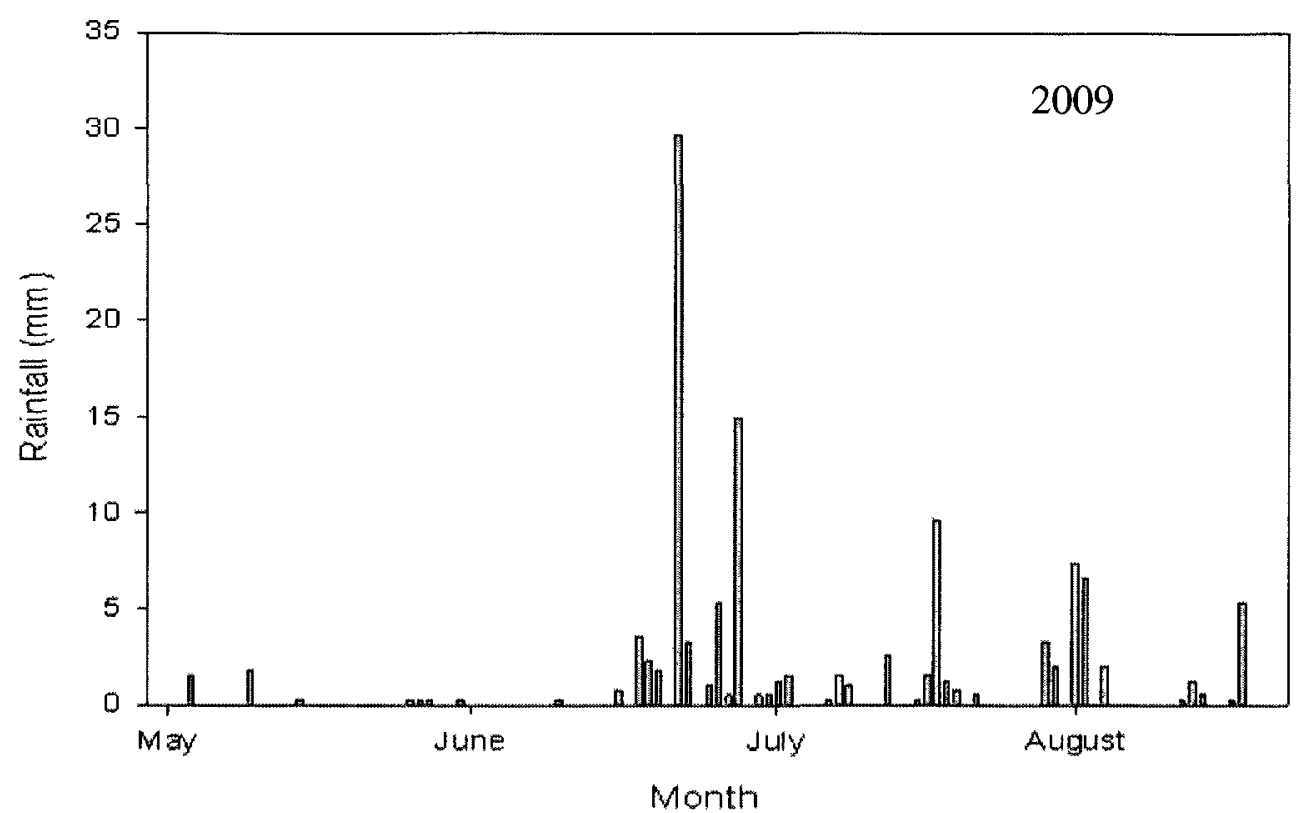

Figure 4.1: Daily rainfall from 1st May to 16th August, 2009. Measurements are recorded within $200 \mathrm{~m}$ of the study site.

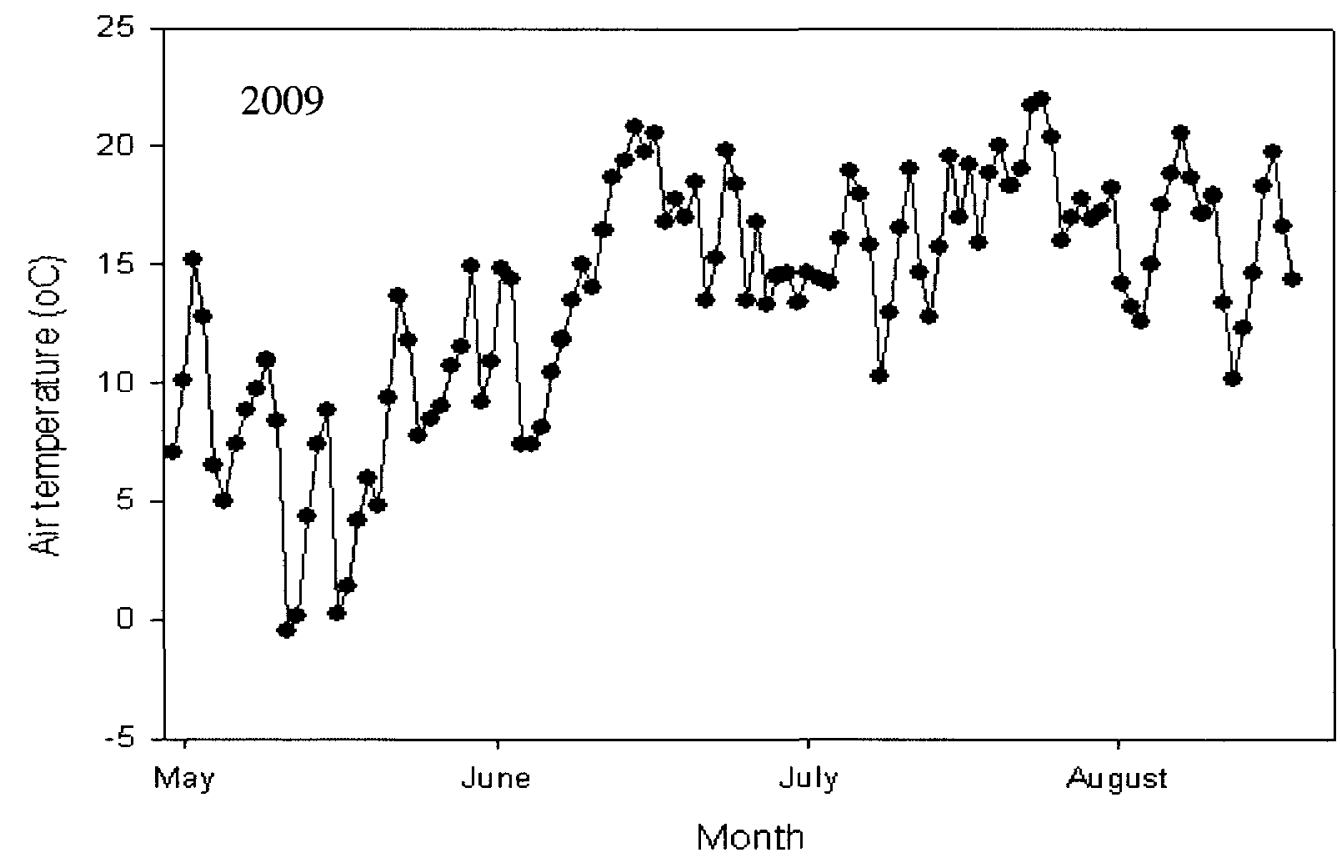

Figure 4.2: Average daily air temperature for the growing season. 
Table 4.1: Monthly average air temperature (Ta) and rainfall data for 2009 growing season at the U-shaped research site, Environment Canada site (from the Fort McMurray airport) and 30-year climate normal (1971-2000) (CN) reported for Fort McMurray, Alberta. For August, research and Environmental Canada site have data only for first 15 days, while for $\mathrm{CN}$ it is for full month.

\begin{tabular}{lllllll}
\hline Month & $\begin{array}{l}\mathrm{T}_{\mathrm{a}}\left({ }^{\circ} \mathrm{C}\right) \\
\begin{array}{l}2009 \\
\text { (Research } \\
\text { site) }\end{array}\end{array}$ & $\begin{array}{l}\mathrm{T}_{\mathrm{a}}\left({ }^{\circ} \mathrm{C}\right) \\
\begin{array}{l}\text { (Environment } \\
\text { Canada) }\end{array}\end{array}$ & $\begin{array}{l}\mathrm{CN} \\
\left({ }^{\circ} \mathrm{C}\right)\end{array}$ & $\begin{array}{l}\text { Rainfall } \\
(\mathrm{mm})\end{array}$ & $\begin{array}{l}\text { Rainfall } \\
(\mathrm{mm}) 2009 \\
\text { (Environment } \\
\text { Canada) }\end{array}$ & $\mathrm{CN}(\mathrm{mm})$ \\
\hline May & 7.9 & 6.9 & 10.4 & 4.6 & 19.6 & 34.2 \\
June & 15.1 & 13.5 & 14.7 & 64.0 & 71.6 & 74.8 \\
site) & & & & & \\
July & 16.9 & 15.4 & 16.8 & 27.9 & 44.8 & 81.2 \\
Aug & 16.0 & 14.7 & 15.3 & 23.6 & 36 & 72.6 \\
\hline
\end{tabular}




\subsection{Variability in NEE, R, GEP, and methane flux among treatments during the 2009 growing season}

In order to reduce the complexity of the datasets for subsequent analysis, preliminary ANOVA and MANOVA analyses were conducted to assess significant differences among the treatments in GEP, R and NEE. The groups for analysis were categorized based on the treatments types. During this preliminary analysis, it was determined that there were no significant differences among treatments on the basis of compaction. Furthermore, no significant difference was observed between summer mineral soil treatments and winter mineral soil treatments. On this basis, treatments were re-categorized into six groups: (i) live summer treatments, (ii) live winter treatments, (iii) peat mix summer treatments, (iv) peat mix winter treatments, (v) mineral soil treatments, and (vi) natural sites.

Multivariate analysis of variance (MANOVA) was performed as a repeated measures analysis to assess whether any significant difference occurred with respect to time, treatments and interaction between time and treatments (Sall et al. 2005). In each case (GEP, R, and NEE), time was not a significant factor, nor was the interaction between time and treatment but treatment did have a significant effect. Tukey's HSD test was used to assess the treatments that were significantly different during the entire growing season for GEP, R, and NEE (Sall et al. 2005).

The following observations were observed for the complete growing season.

1. Natural sites' GEP and $\mathrm{R}$ were significantly different greater than all other treatments (Table 4.2 and Figure 4.3) 
2. Natural sites' NEE were not significantly different than the live treatments (as it is based on the difference between R and GEP (Table 4.2)).

3. $\mathrm{R}$ for peat mix summer and winter treatments were not significantly different from each other (Table 4.2 and Figure 4.3)

4. Peat mix winter treatments' NEE was significantly lower than all the other treatments due to relatively high GEP and relatively low R (Table 4.2 and Figure 4.3). 
Table 4.2: MANOVA (F-values and P-values) and Tukey's HSD results for the full growing season. The significance level (p) was 0.05 and treatments with the same letters were not significantly different for a given flux (NEE, R, GEP or Methane flux). The calculated $\mathrm{F}$ and degree of freedom (df) is also shown.

\begin{tabular}{|c|c|c|c|c|}
\hline $\begin{array}{l}\text { MANOVA df } \\
\text { (num, den) }= \\
\mathbf{5 , 5 4}\end{array}$ & $\mathbf{F}$ & $\mathbf{P}$ & Treatment type & Tukey's HSD \\
\hline \multirow[t]{6}{*}{ NEE } & 16.05 & $<0.0001$ & Live summer treatments & A \\
\hline & & & Live winter treatments & A \\
\hline & & & $\begin{array}{l}\text { Peat mix summer } \\
\text { treatments }\end{array}$ & B \\
\hline & & & $\begin{array}{l}\text { Peat mix winter } \\
\text { treatments }\end{array}$ & $\mathrm{C}$ \\
\hline & & & Mineral soil treatments & B \\
\hline & & & Natural sites & $\mathrm{A}$ \\
\hline \multirow[t]{6}{*}{ GEP } & 7.48 & $<0.0001$ & Live summer treatments & $\mathrm{C}$ \\
\hline & & & Live winter treatments & $\mathrm{D}$ \\
\hline & & & $\begin{array}{l}\text { Peat mix summer } \\
\text { treatments }\end{array}$ & $C, D$ \\
\hline & & & $\begin{array}{l}\text { Peat mix winter } \\
\text { treatments }\end{array}$ & B \\
\hline & & & Mineral soil treatments & $\mathrm{D}$ \\
\hline & & & Natural sites & A \\
\hline \multirow[t]{6}{*}{$\mathbf{R}$} & 34.31 & $<0.0001$ & Live summer treatments & B \\
\hline & & & Live winter treatments & $\mathrm{C}$ \\
\hline & & & $\begin{array}{l}\text { Peat mix summer } \\
\text { treatments }\end{array}$ & $\mathrm{D}$ \\
\hline & & & $\begin{array}{l}\text { Peat mix winter } \\
\text { treatments }\end{array}$ & $\mathrm{D}$ \\
\hline & & & Mineral soil treatments & $\mathrm{E}$ \\
\hline & & & Natural sites & A \\
\hline \multirow[t]{6}{*}{ Methane Flux } & 4.99 & $<0.0001$ & Live summer treatments & A \\
\hline & & & Live winter treatments & A \\
\hline & & & $\begin{array}{l}\text { Peat mix summer } \\
\text { treatments }\end{array}$ & A \\
\hline & & & $\begin{array}{l}\text { Peat mix winter } \\
\text { treatments }\end{array}$ & A \\
\hline & & & Mineral soil treatments & A,B \\
\hline & & & Natural sites & B \\
\hline
\end{tabular}



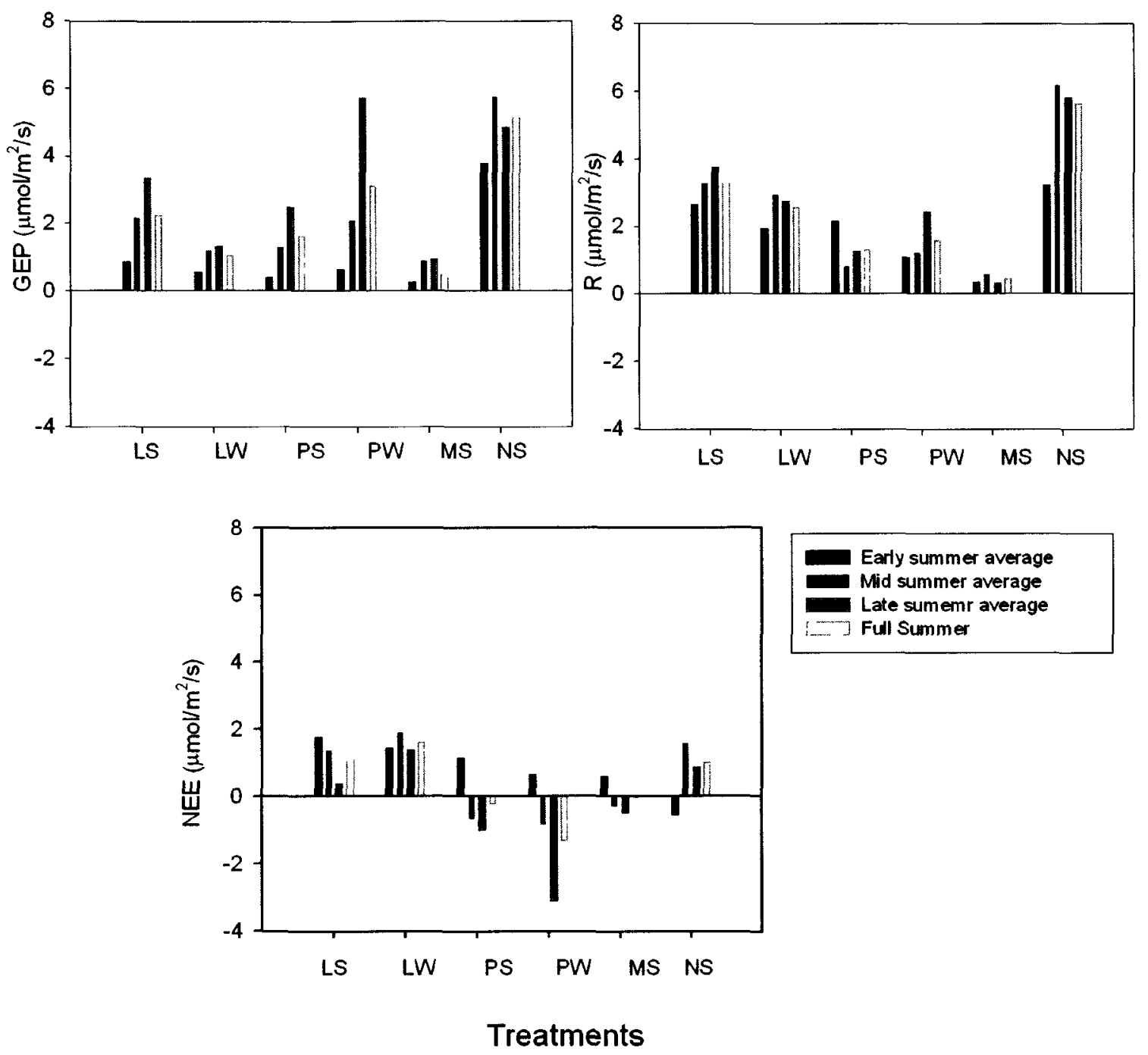

Figure 4.3: Average GEP, R, NEE during early summer, mid summer, late summer and full summer period for the different treatment groups. LS are live summer treatments, LW are live winter treatments, PS are peat mix summer treatments, PW are peat mix winter treatments, MS are mineral soil treatments, and NS are natural sites. 
Treatments had a significant affect on GEP, R and NEE for each season. Tukey's HSD test was then conducted to assess the differences in GEP, R, and NEE in each season and also in between early summer, mid summer and late summer seasons (Figure 4.3 and Table 4.9). Following are important observation noticed among treatments during early, mid, and late summer.

1. Natural sites' GEP were significantly greater than GEP in every other treatment, except for peat mix winter treatments during the late summer season (Figure 4.3).

2. Excluding the natural sites, there were no significant differences in GEP in midsummer for the remaining treatments (Table 4.3 and Figure 4.3).

3. Natural sites' $R$ during mid summer and late summer season was significantly different and greater than other treatments (Figure 4.3 and Table 4.3).

4. During the early season, only natural sites had negative NEE when compared to other treatments (Figure 4.3).

5. The peat mix winter treatments NEE during the late summer season were significantly different and were more negative than all the other treatments (Figure 4.3 and Table 4.3). 
Table 4.3: Turkey's HSD results for NEE, GEP, R and Methane flux based on treatments during early, mid and late summer seasons. The seasonal differences among six different treatments during early, mid, and late summer seasons are shown. The significance level (p) was $0.05 \%$ and treatments with even one similar alphabet are not significantly different to each other. However, different letters among treatments reveals significance difference. The calculated $\mathrm{F}$ and degree of freedom (df) is also showed.

\begin{tabular}{|c|c|c|c|c|}
\hline Treatment Type & Season & & Tukey HSD & \\
\hline & & $\begin{array}{c}\mathrm{df}(\mathrm{F}, \mathrm{P})=17 \\
\left(35.3,<0.0001^{*}\right)\end{array}$ & $\begin{array}{c}\mathrm{df}(\mathrm{F}, \mathrm{P})=17 \\
\left(28.2,<0.0001^{*}\right)\end{array}$ & $\begin{array}{c}\mathrm{df}(\mathrm{F}, \mathrm{P})=17 \\
\left(46.5,<0.0001^{*}\right)\end{array}$ \\
\hline & & NEE & GEP & $\mathrm{R}$ \\
\hline $\begin{array}{l}\text { Live summer } \\
\text { treatments }\end{array}$ & Early Summer & $\mathrm{a}, \mathrm{b}, \mathrm{c}$ & $f, g$ & $\mathrm{c}, \mathrm{d}, \mathrm{e}$ \\
\hline $\begin{array}{c}\text { Live winter } \\
\text { treatments }\end{array}$ & & $a, b, c$ & $\mathrm{~g}$ & $e, f, g$ \\
\hline $\begin{array}{l}\text { Peat mix summer } \\
\text { treatments }\end{array}$ & & $a, b$ & g & $e, f, g$ \\
\hline $\begin{array}{l}\text { Peat mix winter } \\
\text { treatments }\end{array}$ & & $\mathrm{b}, \mathrm{c}, \mathrm{d}, \mathrm{e}$ & $f, g$ & $\mathrm{~g}, \mathrm{~h}$ \\
\hline $\begin{array}{c}\text { Mineral soil } \\
\text { treatments }\end{array}$ & & $a, b, c, d, e, f$ & $\mathrm{c}, \mathrm{d}, \mathrm{e}, \mathrm{f}, \mathrm{g}$ & $\mathrm{g}, \mathrm{h}$ \\
\hline Natural sites & & $c, d, e, f, g$ & $\mathrm{a}, \mathrm{b}, \mathrm{c}, \mathrm{d}, \mathrm{e}$ & $\mathrm{b}, \mathrm{c}, \mathrm{d}, \mathrm{e}, \mathrm{f}$ \\
\hline $\begin{array}{l}\text { Live summer } \\
\text { treatments }\end{array}$ & Mid Summer & $a, b, c, d$ & $c, d, e, f$ & $b, c$ \\
\hline $\begin{array}{l}\text { Live winter } \\
\text { treatments }\end{array}$ & & $\mathrm{a}$ & $e, f, g$ & $b, c, d$ \\
\hline $\begin{array}{l}\text { Peat mix summer } \\
\text { treatments }\end{array}$ & & $f, g$ & $e, f, g$ & $\mathrm{~h}$ \\
\hline $\begin{array}{l}\text { Peat mix winter } \\
\text { treatments }\end{array}$ & & $e, f, g$ & $d, e, f, g$ & $f, g, h$ \\
\hline $\begin{array}{c}\text { Mineral soil } \\
\text { treatments }\end{array}$ & & $e, f, g$ & $f, g$ & $\mathrm{~h}$ \\
\hline Natural sites & & $a, b, c, d$ & $\mathrm{a}$ & $\mathrm{a}$ \\
\hline $\begin{array}{l}\text { Live summer } \\
\text { treatments }\end{array}$ & Late summer & $\mathrm{d}, \mathrm{e}$ & $\mathrm{b}, \mathrm{c}$ & $b$ \\
\hline $\begin{array}{l}\text { Live winter } \\
\text { treatments }\end{array}$ & & $a, b, c, d$ & $e, f, g$ & $\mathrm{c}, \mathrm{d}, \mathrm{e}$ \\
\hline $\begin{array}{l}\text { Peat mix summer } \\
\text { treatments }\end{array}$ & & g & $\mathrm{c}, \mathrm{d}$ & $f, g, h$ \\
\hline $\begin{array}{l}\text { Peat mix winter } \\
\text { treatments }\end{array}$ & & h & $\mathbf{a}$ & d,e \\
\hline $\begin{array}{c}\text { Mineral soil } \\
\text { treatments }\end{array}$ & & $e, f, g$ & d,e,f,g & $\mathrm{h}$ \\
\hline Natural sites & & $\mathrm{a}, \mathrm{b}, \mathrm{c}, \mathrm{d}, \mathrm{e}$ & $a, b$ & $\mathrm{a}$ \\
\hline
\end{tabular}




\subsection{LAI, Surface Temperature, and VWC trends}

\subsubsection{LAI trends during 2009 growing season}

For the peat mix treatments, mineral soil treatments, and natural sites, LAI were lowest in early summer. Natural sites and Mineral sites LAI increased to peak values during the mid-summer and then declined again in the late season (Table 4.4). For the peat mix summer treatments values stayed the same during mid and late summer, however, for the peat mix winter treatments it increased throughout the season. For the live winter treatments no variation in LAI was noticed during the season, however, for the live summer treatments, LAI stayed similar during early and mid summer, but eventually, it decreased slightly during the early summer (Table 4.4).

The highest LAI of $2.5 \pm 2.1 \mathrm{~m}^{2} \mathrm{~m}^{-2}$ was recorded for the natural sites during midsummer season. Among the live treatments, the highest LAI of $0.9 \pm 0.6 \mathrm{~m}^{2} \mathrm{~m}^{-2}$ was recorded for the live summer treatments. Among the peat mix treatments, peat mix winter treatments had the highest LAI of $1.0 \pm 0.7 \mathrm{~m}^{2} \mathrm{~m}^{-2}$ during the late summer season. The lowest LAI during the full growing season was recorded for the mineral soil treatments (Table 4.4). 
Table 4.4: Average LAI $\left(\mathrm{m}^{2} \mathrm{~m}^{-2}\right)$ values with standard deviation for each treatment during three early, mid and late summer seasons. Early season is from DOY138-DOY 164, mid season is from DOY 165-195 and late season is from DOY 196-DOY 228.

\begin{tabular}{llll}
\hline Treatment Type & Early Season LAI & Mid Season LAI & Late Season LAI \\
\hline $\begin{array}{l}\text { Live summer } \\
\text { treatments }\end{array}$ & $0.9 \pm 0.7$ & $0.9 \pm 0.6$ & $0.8 \pm 0.6$ \\
$\begin{array}{l}\text { Live winter } \\
\text { treatments }\end{array}$ & $0.5 \pm 0.3$ & $0.5+0.3$ & $0.5 \pm 0.5$ \\
$\begin{array}{l}\text { Peat mix summer } \\
\text { treatments }\end{array}$ & $0.2 \pm 0.2$ & $0.4 \pm 0.3$ & $0.4 \pm 0.5$ \\
$\begin{array}{l}\text { Peat mix winter } \\
\text { treatments }\end{array}$ & $0.1 \pm 0.1$ & $0.5 \pm 0.2$ & $1.0 \pm 0.7$ \\
$\begin{array}{l}\text { Natural sites } \\
\begin{array}{l}\text { Mineral soil } \\
\text { treatments }\end{array}\end{array}$ & $2.1 \pm 1.8$ & & \\
\hline
\end{tabular}




\subsubsection{Surface temperature trends during 2009 growing season}

Among live treatments, live winter treatments had the highest temperature of $23.9^{\circ} \mathrm{C} \pm 1.5$. Natural sites recorded the highest temperature of $24.1 \pm 1.2$ among all the different treatments during the growing season. Meanwhile, among all peat mix treatments, the peat mix winter treatments recorded the highest temperature of $23.5 \pm 0.9$ (Table 4.5). 
Table 4.5: Average surface temperature with standard deviation for each treatment types during early, mid and late summer seasons.

\begin{tabular}{llll}
\hline Treatment Type & $\begin{array}{l}\text { Early Season } \\
\text { Surface } \\
\text { temperature }\left({ }^{\circ} \mathrm{C}\right)\end{array}$ & $\begin{array}{l}\text { Mid Season } \\
\text { Surface } \\
\text { temperature }\end{array}$ & $\begin{array}{l}\text { Late Season } \\
\text { Surface } \\
\text { temperature }\left({ }^{\circ} \mathrm{C}\right)\end{array}$ \\
\hline $\begin{array}{l}\text { Live summer } \\
\text { treatments }\end{array}$ & $18.3 \pm 2.3$ & $23.2 \pm 1.2$ & $22.0 \pm 1.0$ \\
$\begin{array}{l}\text { Live winter } \\
\text { treatments }\end{array}$ & $16.1 \pm 2.1$ & $23.9 \pm 1.5$ & $23.7 \pm 1.1$ \\
$\begin{array}{l}\text { Peat mix summer } \\
\text { treatments }\end{array}$ & $16.4 \pm 2.8$ & $21.1 \pm 1.4$ & $21.4 \pm 1.4$ \\
$\begin{array}{l}\text { Peat mix winter } \\
\text { treatments }\end{array}$ & $15.6 \pm 2.1$ & $22.2 \pm 1.2$ & $23.5 \pm 0.9$ \\
$\begin{array}{l}\text { Natural sites } \\
\text { Mineral soil } \\
\text { treatments }\end{array}$ & $20.0 \pm 2.9$ & $24.1 \pm 1.2$ & $23.2 \pm 1.9$ \\
\hline
\end{tabular}




\subsubsection{VWC trends during 2009 growing season}

For all treatments, VWC was greater in mid and late summer as the cells were being watered constantly at that point (Table 4.6). Mineral soil treatments, presumably due to lower soil porosity, had the lowest VWC of all treatments in mid and late summer. The seasonal VWC for few treatments was greater than $100 \%$, which was instrumental error that can occur under saturated conditions. It was only at natural sites where relatively low and constant VWC was recorded during the growing season (Table 4.6). No soil moisture data was available for the peat mix treatments with mine water as the moisture probe is not calibrated for high salt concentrations (Table 4.6). 
Table 4.6: Average VWC values with standard deviation for each treatment type during early, mid and late summer seasons.

\begin{tabular}{llll}
\hline Treatment Type & $\begin{array}{l}\text { Early Season VWC } \\
(\%)\end{array}$ & $\begin{array}{l}\text { Mid Season VWC } \\
(\%)\end{array}$ & $\begin{array}{l}\text { Late Season VWC } \\
(\%)\end{array}$ \\
\hline $\begin{array}{l}\text { Live summer } \\
\text { treatments }\end{array}$ & $70 \pm 23$ & $98 \pm 13$ & $93 \pm 11$ \\
$\begin{array}{l}\text { Live winter } \\
\text { treatments }\end{array}$ & $56 \pm 19$ & $96 \pm 10$ & $97 \pm 8$ \\
$\begin{array}{l}\text { Peat mix summer } \\
\text { treatments }\end{array}$ & $64 \pm 16$ & $103 \pm 8$ & $100 \pm 9$ \\
$\begin{array}{l}\text { Peat mix winter } \\
\text { treatments }\end{array}$ & $74 \pm 23$ & $103 \pm 10$ & $100 \pm 11$ \\
$\begin{array}{l}\text { Natural sites } \\
\text { Mineral soil } \\
\text { treatments }\end{array}$ & $56 \pm 5$ & $60 \pm 2$ & $54 \pm 2$ \\
\hline
\end{tabular}




\subsection{Seasonal GEP trend for the 2009 growing season}

In general, GEP increased through the growing season as growing conditions improved and the amount of green plant material increased as shown by an increase in LAI, soil temperature and VWC (Figure 4.4 through Figure 4.10). At most sites, GEP peaked during the late season when optimum temperature was around $22^{\circ} \mathrm{C}$ and VWC was in the range of $88 \%-100 \%$.

In terms of the effects of treatments on the seasonal variation in GEP as well as on the seasonal average GEP, there was no consistent effect of depth of peat on GEP for all the treatments. Overall, the compaction of both live and peat mix treatments did not have any affect on average GEP during the growing season. Live summer treatment had slightly greater GEP than live winter treatments. However, for peat mix treatments winter treatments had considerable higher GEP than the summer treatment. The peat mix treatments had greater GEP and seasonal variability than the live treatments. As with the seasonal variations in LAI and VWC, seasonal variations in GEP were quite different at the natural sites when compared to most of the research cells. Overall, during the full growing season, GEP was highest at the natural sites (Table 4.7). Natural sites also had the highest variability in GEP due to natural fluctuations in VWC and soil temperature during the growing season, as they were not artificially watered while LAI remained relatively high. Natural sites 3 and 4 had the greatest GEP throughout the season compared to Natural sites 1 and 2 due to greater LAI.

Among the $\mathrm{U}$-shaped cells, some of the more notable differences in GEP are (Table 4.7): 
1. Mineral soil treatments had the lowest GEP and the least seasonal variability. Cell (M_20_w) (B) was the only exception, where GEP increased through the growing season (Figure 4.9 and Table 4.7).

2. The GEP for live summer treatments with or without compaction was greater than live winter treatments and was associated with relatively higher LAI (Figures 4.4 and 4.5). This resulted in greater increase in GEP with time for the live summer treatments. Among all the live treatments, no trend was observed between GEP and peat depth. As a result, higher peat depths do not necessarily have greater GEP. For example, (L_15_s) (A), which is a shallow peat, had a greater GEP than other treatments (maximum GEP of $7.8 \mu \mathrm{mol} \mathrm{m}^{-2} \mathrm{~s}^{-1}$ on DOY 226). Similarly, among the winter treatments, the greatest GEP $\left(3.4 \mu \mathrm{mol} \mathrm{m}{ }^{-2}\right.$ $\mathrm{s}^{-1}$ ) was recorded for cell $\mathrm{L}_{-} 15 \_\mathrm{w}_{-} \mathrm{c}$ (A) on DOY 220 . This is simply a coincidence that treatments with $15 \mathrm{~cm}$ depth recorded the greatest GEP on a specific day for the summer and winter treatments. Overall, no recognizable trend was visible during the full growing season.

3. In contrast, peat mix winter treatments had greater seasonal increases in GEP than peat mix summer treatments, again presumably due to greater increases in LAI in the winter treatments. Towards the end of the season cells (P_100_w) (A), $\left(\mathrm{P} \_50 \_w\right)(B),\left(P \_50 \_w \_c\right)(A)$, and $\left(P \_100 \_w \_c\right)(B)$ showed the greatest increase in GEP (Figure 4.6-Figure 4.7). Unlike the live treatments, a trend in GEP was noticed based on the peat depth. The cells with greater depth had larger GEP, particularly after the mid-growing season. Peat mix summer treatments also showed higher deviation in GEP than the peat mix winter 
4. treatments during the growing season. This was related to the considerable variability in LAI among treatments towards the end of the growing season (Table 4.7, Figure 4.6-Figure 4.7).

5. The $15 \mathrm{~cm}$ peat mix with mine water treatment had only a slight increase in GEP until DOY 165 after which GEP gradually dropped to near zero by DOY 185 when LAI was also recorded to be zero. In contrast, one of the collars in the $100 \mathrm{~cm}$ peat mix with mine water treatment had a relatively consistent increase in GEP with time (Figure 4.8). 

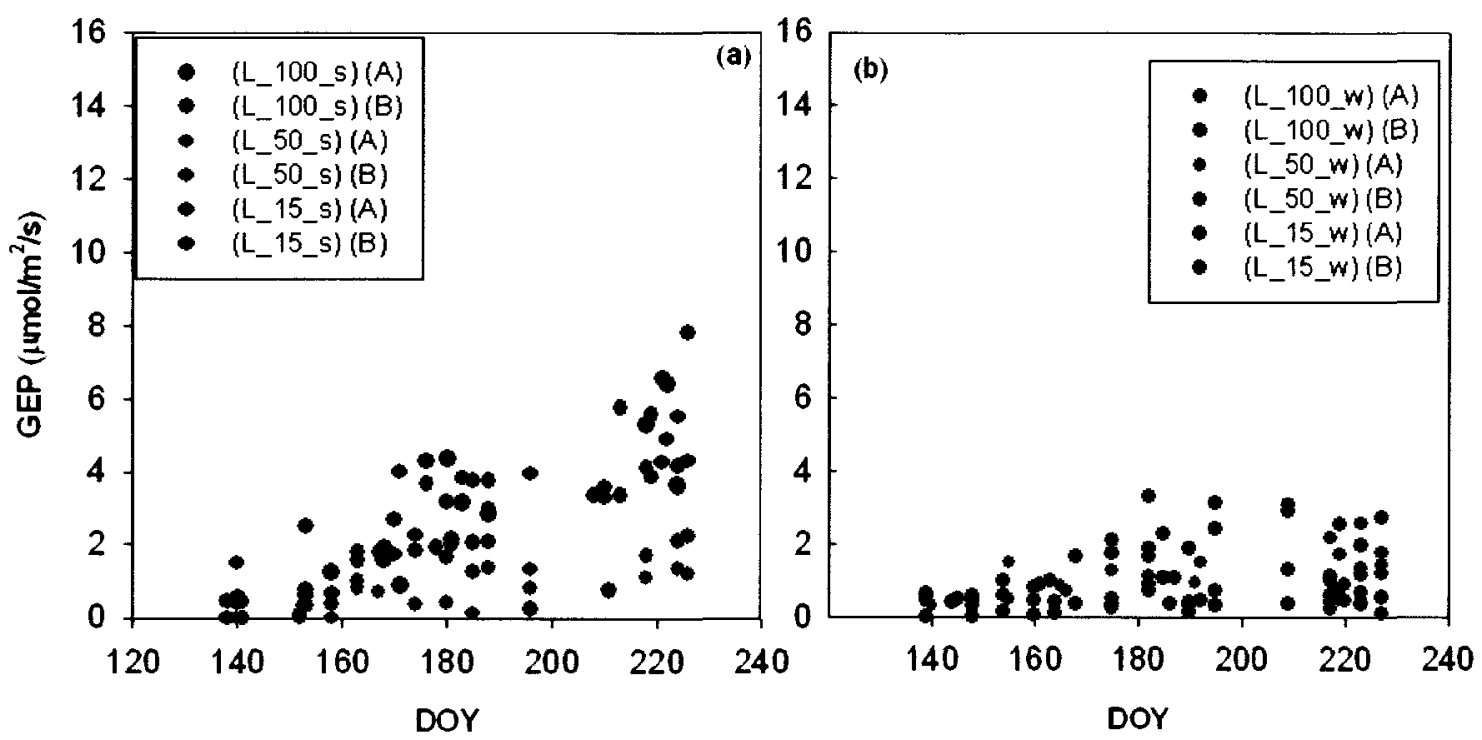

Figure 4.4: Seasonal trends in GEP for live treatments with no compaction for both summer (a) and winter (b) during the growing season of 2009.
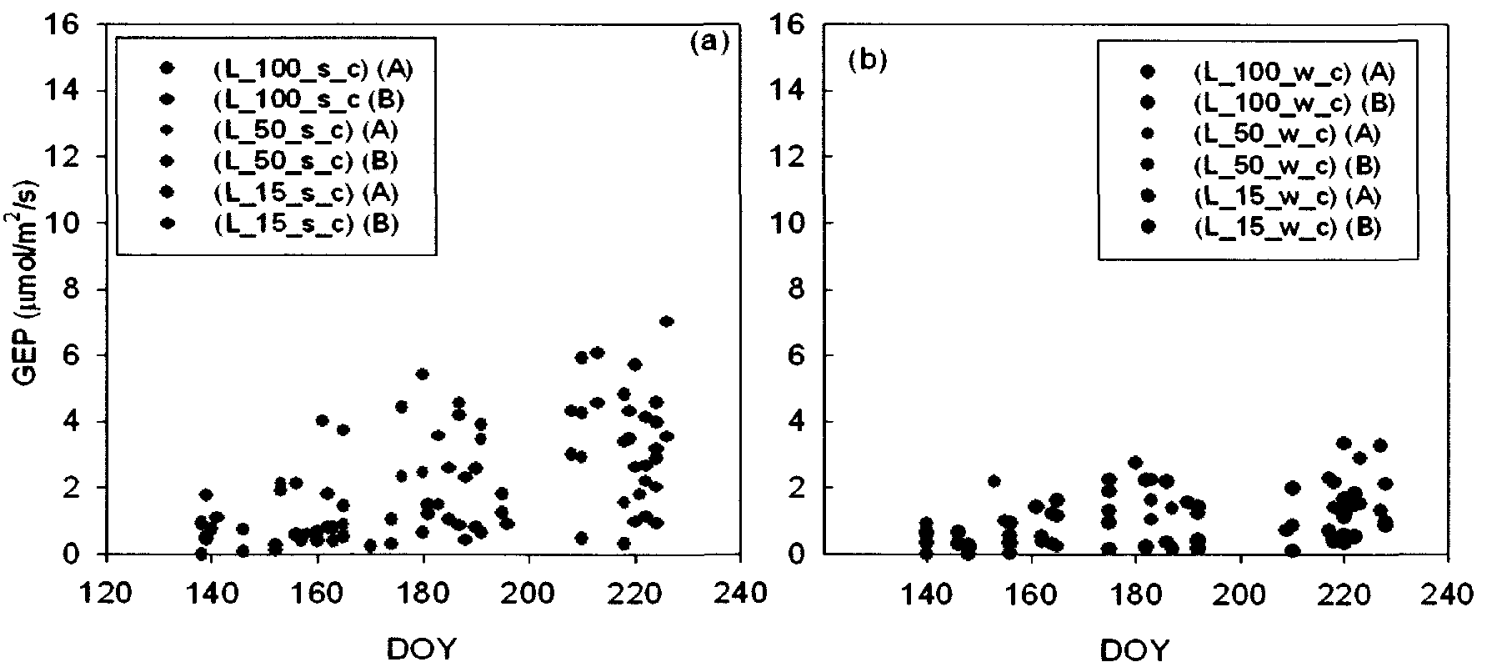

Figure 4.5: Seasonal trends in GEP for live treatments with compaction for summer (a) and winter (b) during the growing season of 2009. 

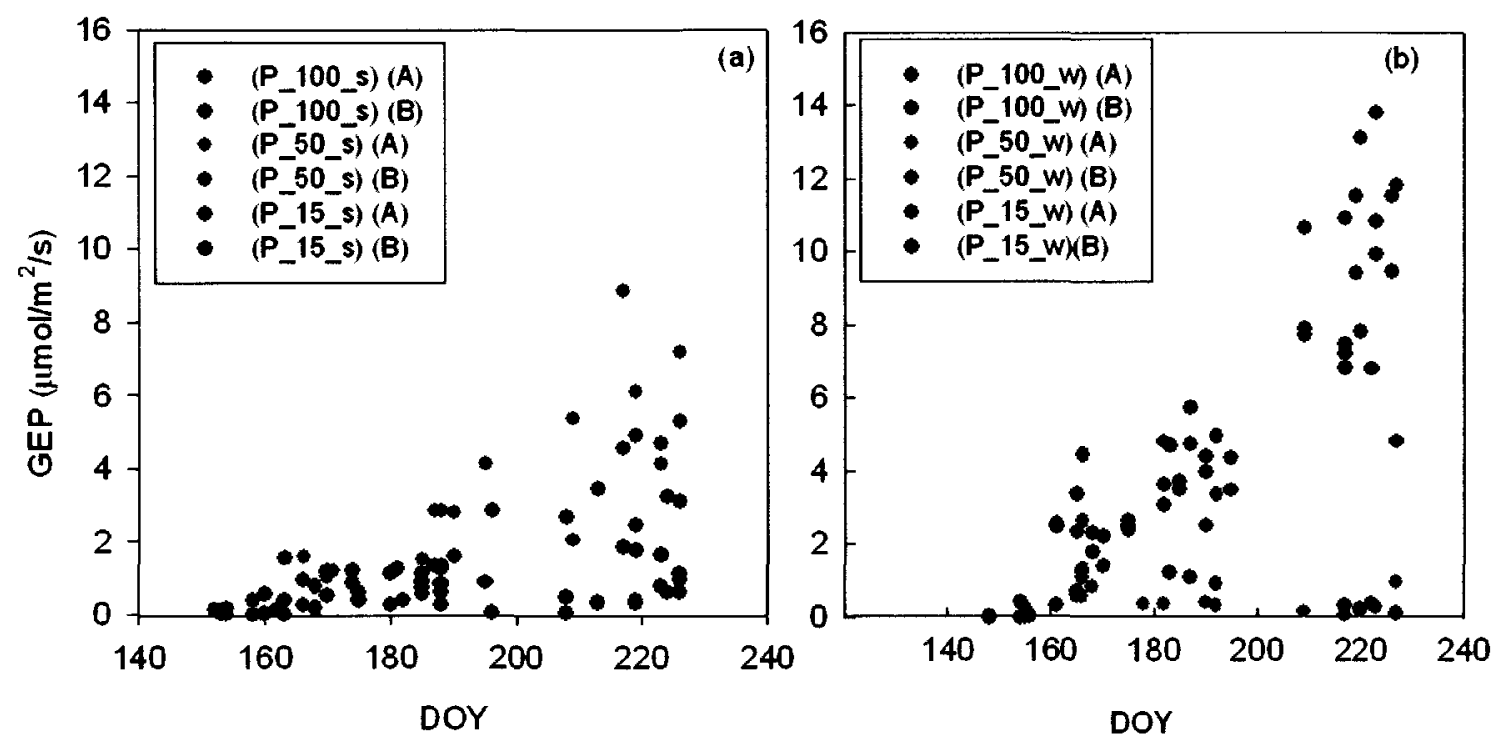

Figure 4.6: Seasonal trends in GEP for peat mix treatments with no compaction for summer (a) and winter (b) during the growing season of 2009.
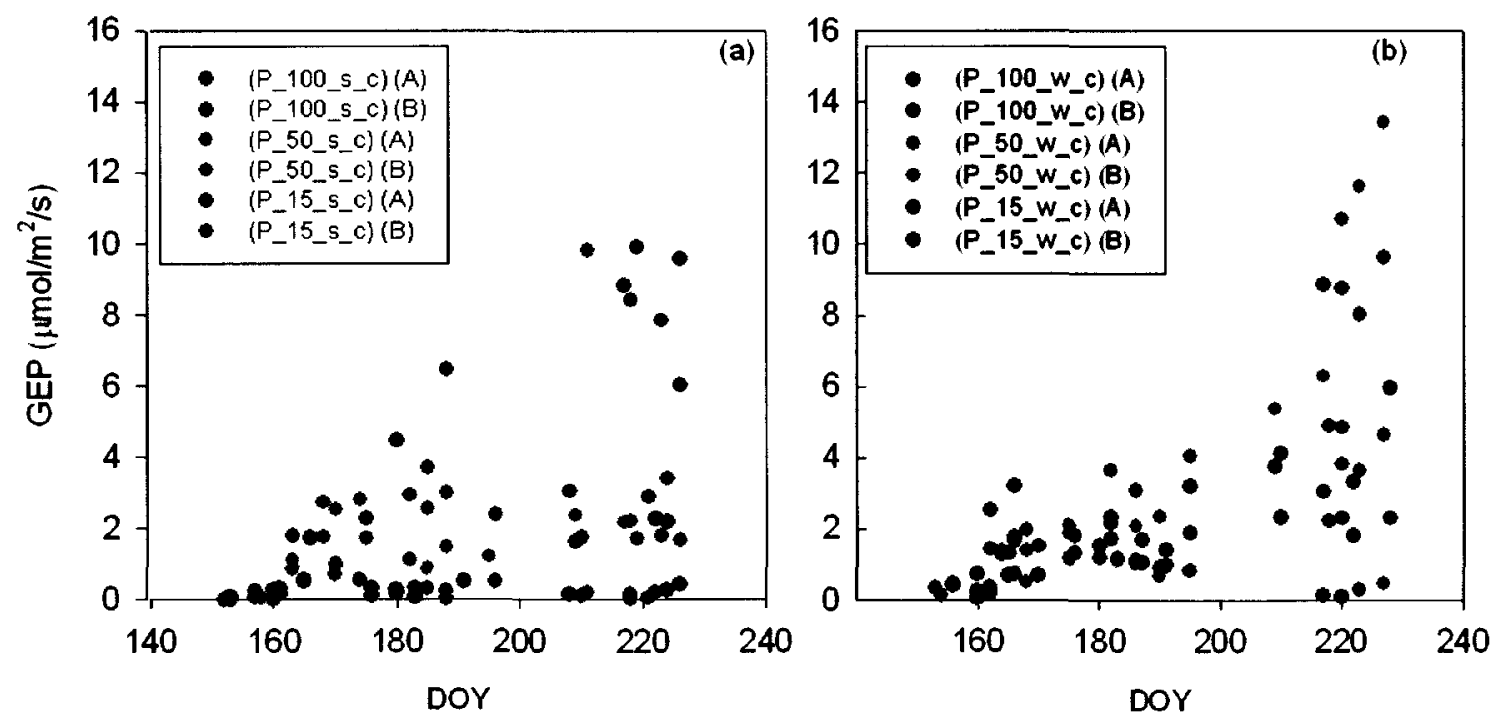

Figure 4.7: Seasonal trends in GEP for peat mix treatments with compaction for summer (a) and winter (b) during the growing season of 2009. 


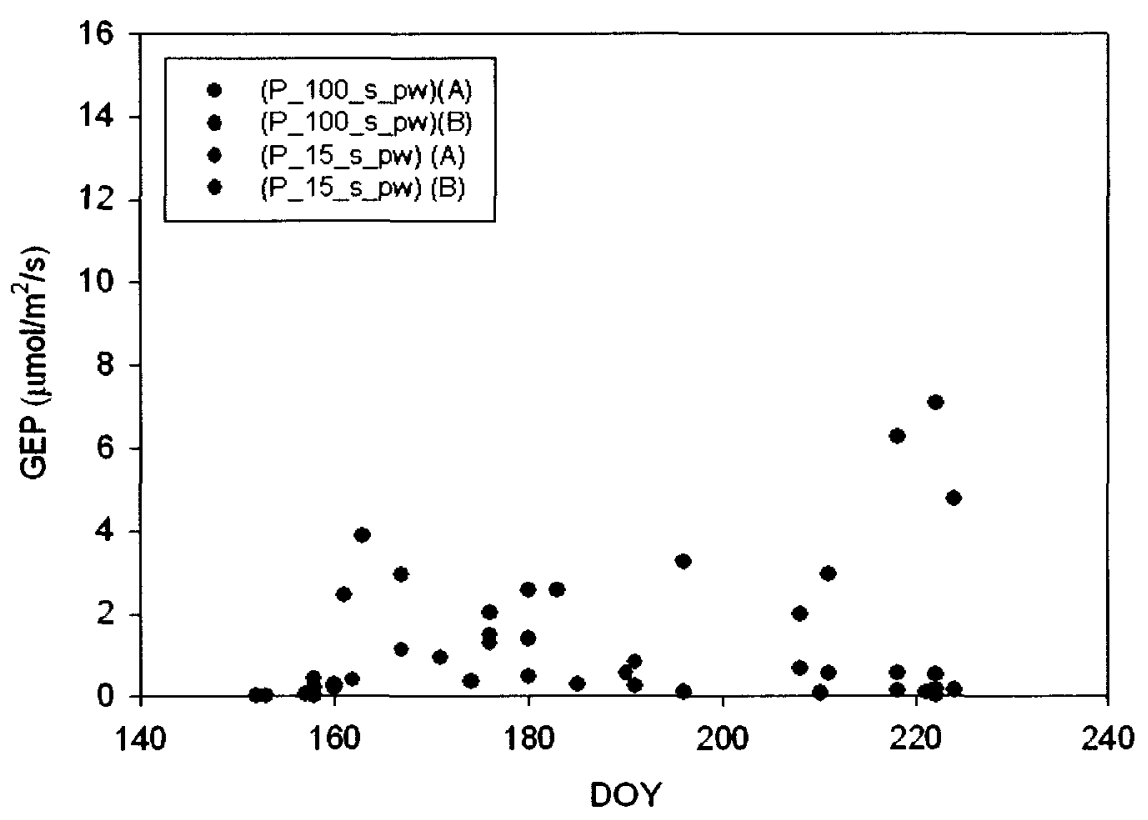

Figure 4.8: Seasonal trends in GEP for peat mix treatments with mine water during the growing season of 2009 .

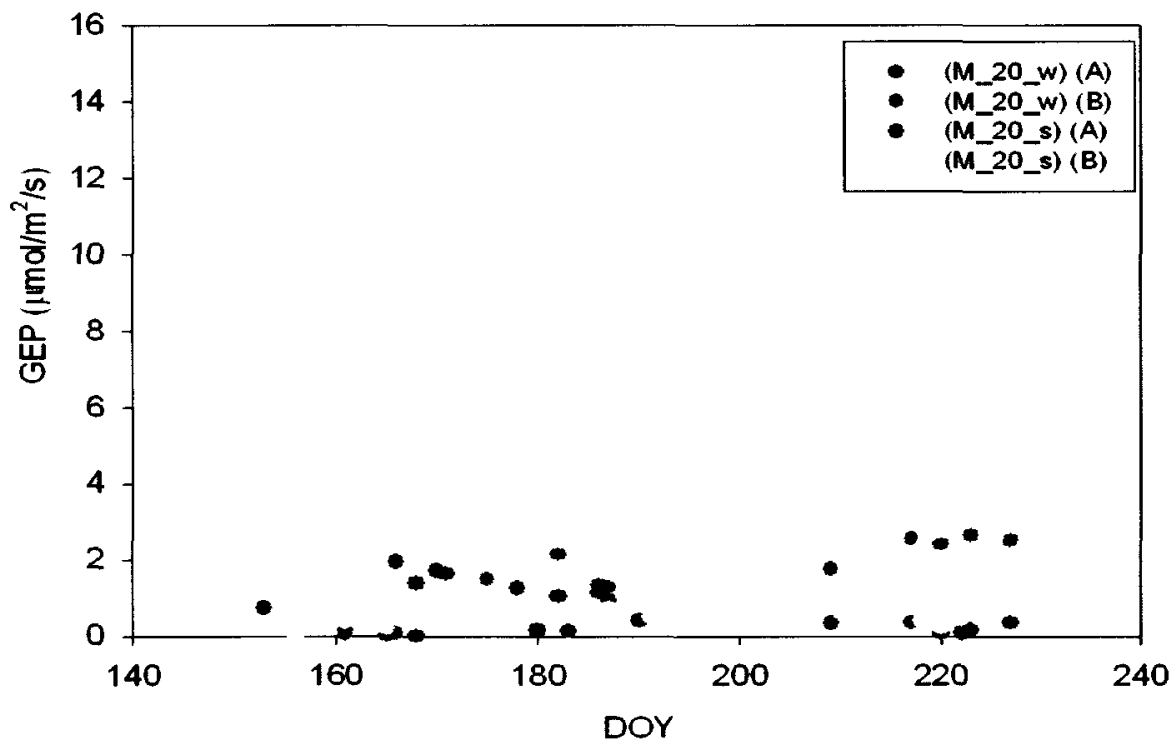

Figure 4.9: Seasonal trends in GEP for mineral soil treatments during the growing season of 2009 . 


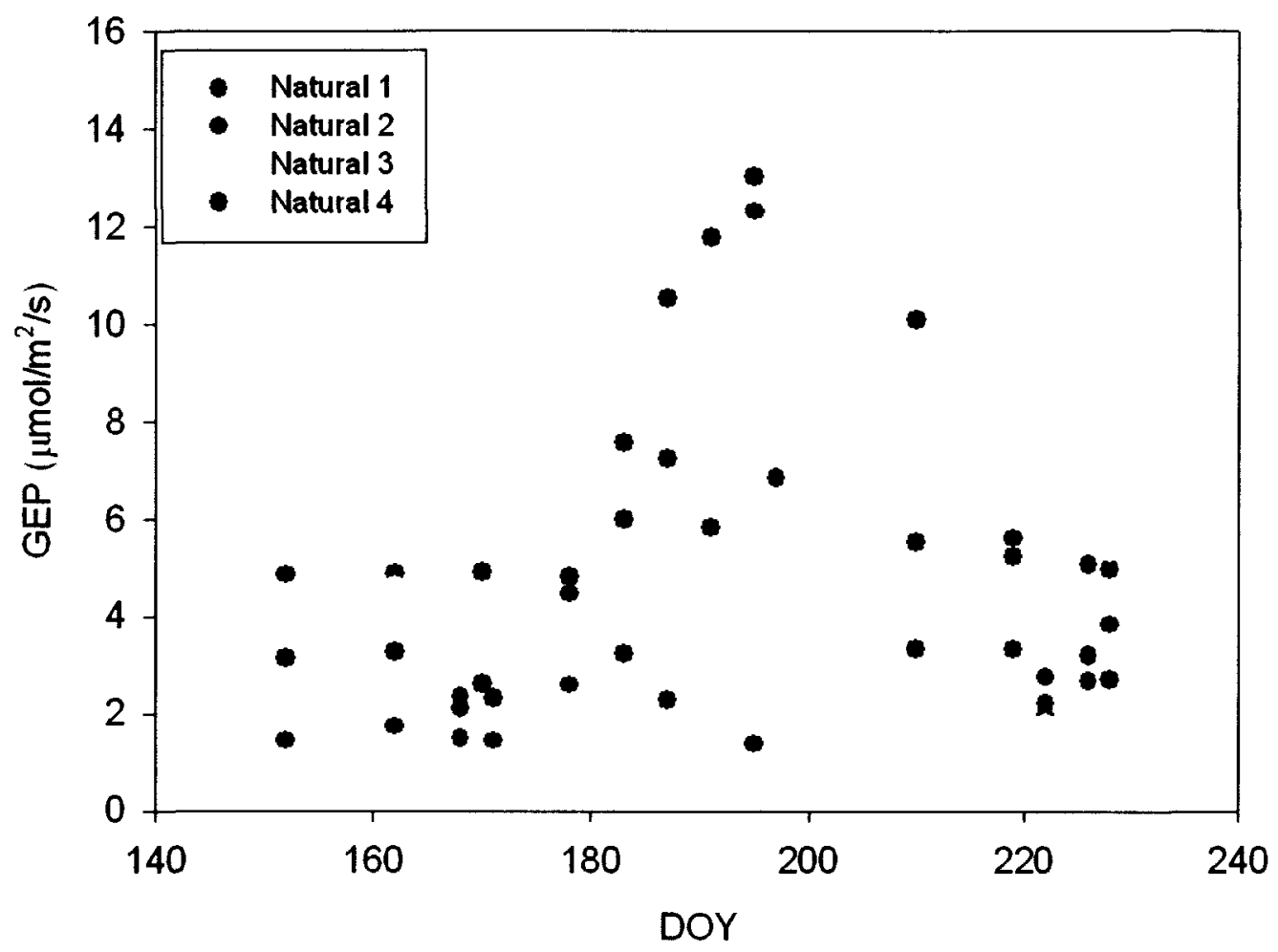

Figure 4.10: Seasonal trends in GEP for natural sites during the growing season of 2009. 
Table 4.7: Average measured GEP \pm standard deviation for each of the different treatments during early (ES), mid (MS), late (LS) and full growing season.

\begin{tabular}{|c|c|c|c|c|}
\hline Treatments & $\begin{array}{l}\text { Average flux } \\
\text { (ES) } \\
\mu \mathrm{mol} \mathrm{m}^{-2} \mathrm{~s}^{-1}\end{array}$ & $\begin{array}{l}\text { Average flux } \\
\text { (MS) } \\
\mu \mathrm{mol} \mathrm{m}^{-2} \mathrm{~s}^{-1}\end{array}$ & $\begin{array}{l}\text { Average flux } \\
\text { (LS) } \\
\mu \mathrm{mol} \mathrm{m}^{-2} \mathrm{~s}^{-1}\end{array}$ & $\begin{array}{l}\text { Full growing } \\
\text { season flux } \\
\left(\mu \mathrm{mol} \mathrm{C} \mathrm{m}^{-2}\right)\end{array}$ \\
\hline $\begin{array}{l}\text { Live summer with } \\
\text { no compaction }\end{array}$ & $0.9 \pm 0.6$ & $2.3 \pm 1.3$ & $3.6 \pm 1.9$ & $212.6 \pm 117.4$ \\
\hline $\begin{array}{l}\text { Live summer with } \\
\text { compaction }\end{array}$ & $1.0 \pm 0.9$ & $2.1 \pm 1.5$ & $3.1 \pm 1.7$ & $193.2 \pm 126.4$ \\
\hline $\begin{array}{c}\text { Live summer } \\
\text { treatments (total } \\
\text { average) }\end{array}$ & $1.0 \pm 0.8$ & $2.2 \pm 1.3$ & $3.3 \pm 1.8$ & $202.9 \pm 121.9$ \\
\hline $\begin{array}{l}\text { Live winter with } \\
\text { no compaction }\end{array}$ & $0.60 \pm 0.3$ & $1.2 \pm 0.8$ & $1.2 \pm 0.8$ & $91.6 \pm 62.3$ \\
\hline $\begin{array}{l}\text { Live winter with } \\
\text { compaction }\end{array}$ & $0.7 \pm 0.5$ & $1.2 \pm 0.8$ & $1.4 \pm 0.9$ & $101.4 \pm 67.1$ \\
\hline $\begin{array}{c}\text { Live winter } \\
\text { treatments (total } \\
\text { average) }\end{array}$ & $0.6 \pm 0.4$ & $1.2 \pm 0.8$ & $1.3 \pm 0.8$ & $96.5 \pm 64.7$ \\
\hline $\begin{array}{c}\text { Peat mix summer } \\
\text { with no } \\
\text { compaction }\end{array}$ & $0.3 \pm 0.5$ & $1.1 \pm 0.8$ & $2.6 \pm 2.3$ & $130.3 \pm 113.7$ \\
\hline $\begin{array}{l}\text { Peat mix summer } \\
\text { with compaction }\end{array}$ & $0.5 \pm 0.6$ & $1.5 \pm 1.5$ & $2.9 \pm 3.2$ & $156.0 \pm 165.1$ \\
\hline $\begin{array}{c}\text { Peat mix summer } \\
\text { treatments (total } \\
\text { average) }\end{array}$ & $0.4 \pm 0.5$ & $1.3 \pm 1.2$ & $2.8 \pm 2.8$ & $143.2 \pm 139.4$ \\
\hline $\begin{array}{c}\text { Peat mix winter } \\
\text { with no } \\
\text { compaction }\end{array}$ & $0.9 \pm 1.1$ & $2.5 \pm 1.6$ & $6.3 \pm 4.7$ & $\begin{array}{c}309.2 \pm \\
234.7\end{array}$ \\
\hline $\begin{array}{l}\text { Peat mix winter } \\
\text { with compaction }\end{array}$ & $0.7 \pm 0.7$ & $1.7 \pm 0.8$ & $4.7 \pm 3.5$ & $224.7 \pm 161.5$ \\
\hline $\begin{array}{c}\text { Peat mix winter } \\
\text { treatments (total } \\
\text { average) }\end{array}$ & $0.8 \pm 0.8$ & $2.1 \pm 1.3$ & $5.5 \pm 4.2$ & $267.9 \pm 198.1$ \\
\hline $\begin{array}{c}\text { Mineral soil } \\
\text { treatments }\end{array}$ & $0.3 \pm 0.3$ & $0.9 \pm 0.6$ & $0.9 \pm 1.0$ & $65.2 \pm 60.4$ \\
\hline $\begin{array}{l}\text { Peat mix with mine } \\
\text { water treatments }\end{array}$ & $1.0 \pm 1.4$ & $1.3 \pm 0.9$ & $1.5 \pm 2.2$ & $115.4 \pm 137.2$ \\
\hline Natural Sites & $3.8 \pm 1.6$ & $5.8 \pm 3.7$ & $4.8 \pm 2.4$ & $439.1 \pm 238.3$ \\
\hline
\end{tabular}




\subsection{Seasonal $R$ trend for 2009 growing season}

In contrast to the seasonal trends for GEP, there was a smaller relative increase in $\mathrm{R}$ throughout the growing season for most of the treatments and in a number of treatments, $\mathrm{R}$ either remained constant or decreased to some extent (Figures 4.11 through 4.17). These trends were associated with treatment type and environmental parameters, which include LAI, VWC, and soil temperature.

For all the treatments, peat depth does not have a consistent effect on $\mathrm{R}$ during the growing season. The compacted treatments had slightly higher $\mathrm{R}$ for both live and peat mix treatments during the growing season. The live summer treatments had greater $\mathrm{R}$ than live winter treatments during the growing season, though, opposite was noticed for the peat mix treatments as winter treatments had higher $\mathrm{R}$ than summer ones. Respiration was observed to be considerable greater for live treatments than peat mix treatments during the growing season. The standard deviation from the seasonal mean value was observed to be slightly greater for live winter treatments than live summer treatment, presumably due to greater fluctuations in soil temperature. Furthermore, peat mix treatments had higher standard deviation for the summer treatments than winter treatments, presumably due to greater fluctuations in LAI. Mineral soil treatments had the lowest $\mathrm{R}$ among all the treatments during the growing season due primarily to limited LAI and higher soil moisture (Table 4.4, Table 4.5, Table 4.6, and Table 4.8). In contrast, highest $\mathrm{R}$ during the growing season was observed at the natural sites, most likely as it was the only treatment where no re-wetting was in effect (Table 4.4, Table 4.5, Table 4.6, and Table 4.8). Natural sites were the only treatments where R peaked mid-season. The 
highest $\mathrm{R}$ of $14.9 \mu \mathrm{mol} \mathrm{m}^{-2} \mathrm{~s}^{-1}$ was recorded for Natural 1 on DOY 195 (Figure 4.17 and Table 4.8).

Among the U-shaped cells, some of the more notable differences in $\mathrm{R}$ are (Table 4.8):

1. Among the live summer treatments, a high degree of variability in $R$ was noticed during the growing season. The cell (L_50_s) (A) and Cell (L_15_s_c) (B) exhibited a different trend then live summer treatments as a sudden decrease in $\mathrm{R}$ was noticed around DOY 180 . Live winter treatments showed less variability in $\mathrm{R}$ during the growing season in comparison to that of live summer treatments (Figure 4.11 and Figure 4.12).

2. Peat mix with mine water showed lower $R$ than all the treatments except for the mineral soil treatment. Also, between these two treatments, the mineral soil treatments had greater temporal in $\mathrm{R}$ as the season progressed (Figure 4.15 and Table 4.8).

3. In contrast, $\mathrm{R}$ declined in the peat mix summer treatments until the mid-summer season; however, after that an increase in $\mathrm{R}$ was observed. Peat mix winter treatment had a gradual increase in R. Peat mix summer treatments had lower $\mathbf{R}$ with higher variability than the peat mix winter treatments (Figure 4.13 and Figure 4.14).

4. Mineral soil treatments had lowest $\mathrm{R}$ during the growing season. With the exception of few days, $\mathrm{R}$ was always less than $1 \mu \mathrm{mol} \mathrm{m} \mathrm{m}^{-2} \mathrm{~s}^{-1}$ (Figure 4.16). 

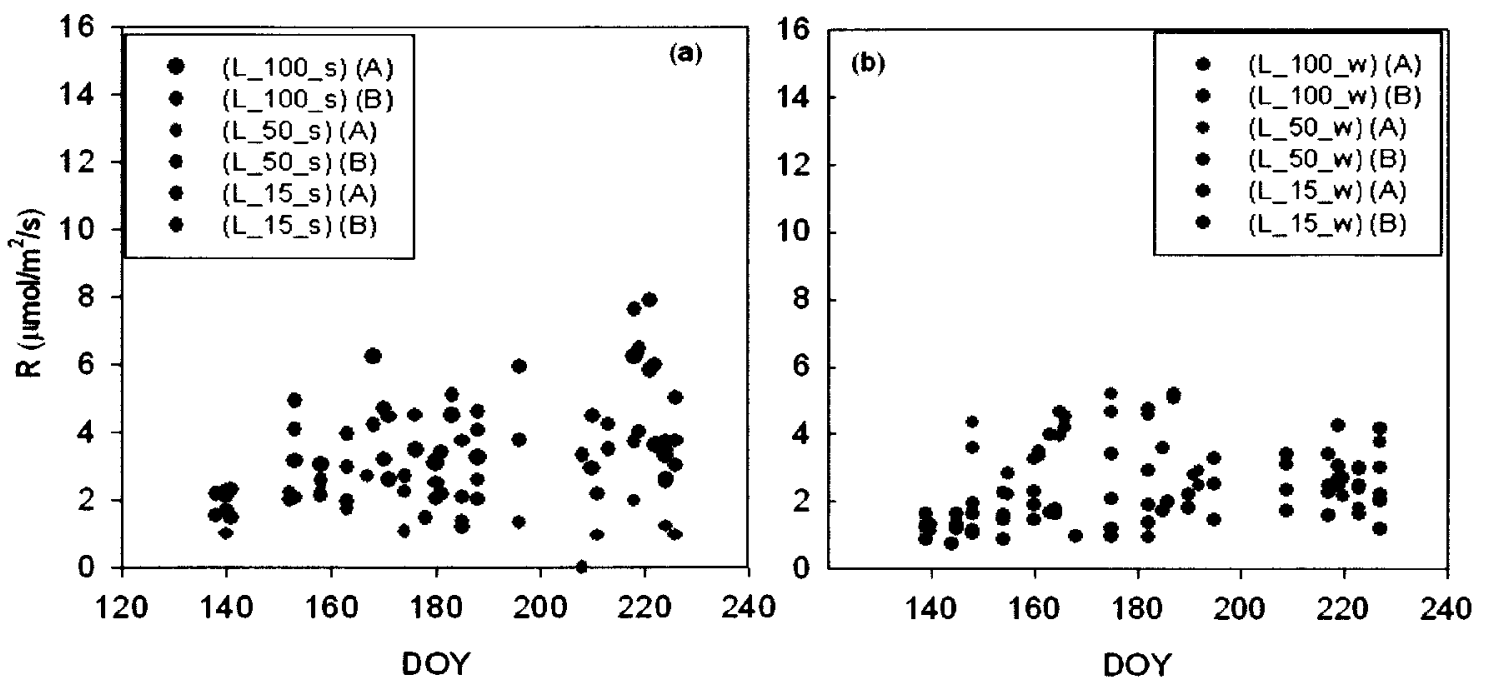

Figure 4.11: Seasonal trends in $\mathrm{R}$ for live treatments with no compaction for summer (a) and winter (b) during the growing season of 2009.
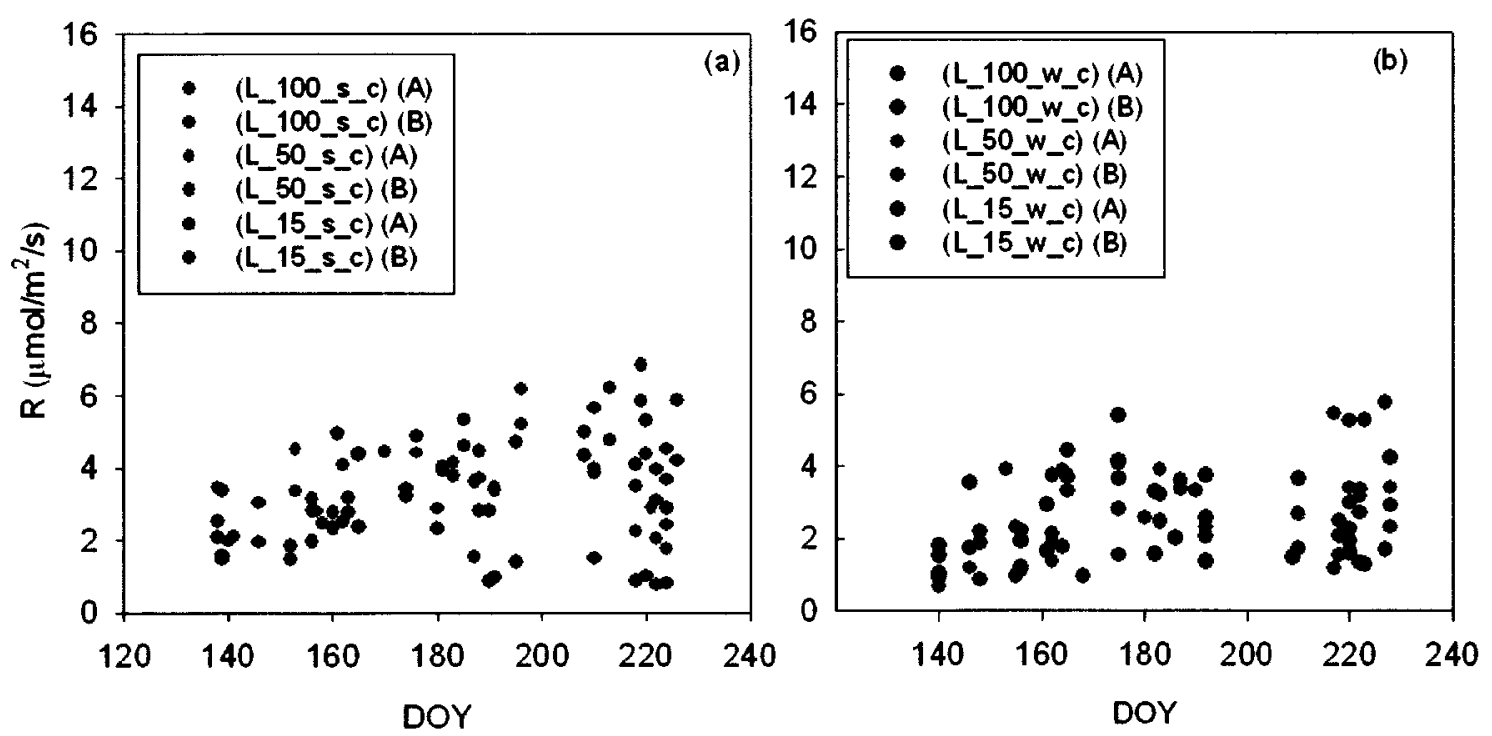

Figure 4.12: Seasonal trends in $\mathrm{R}$ for live treatments with compaction for summer (a) and winter (b) during the growing season of 2009. 

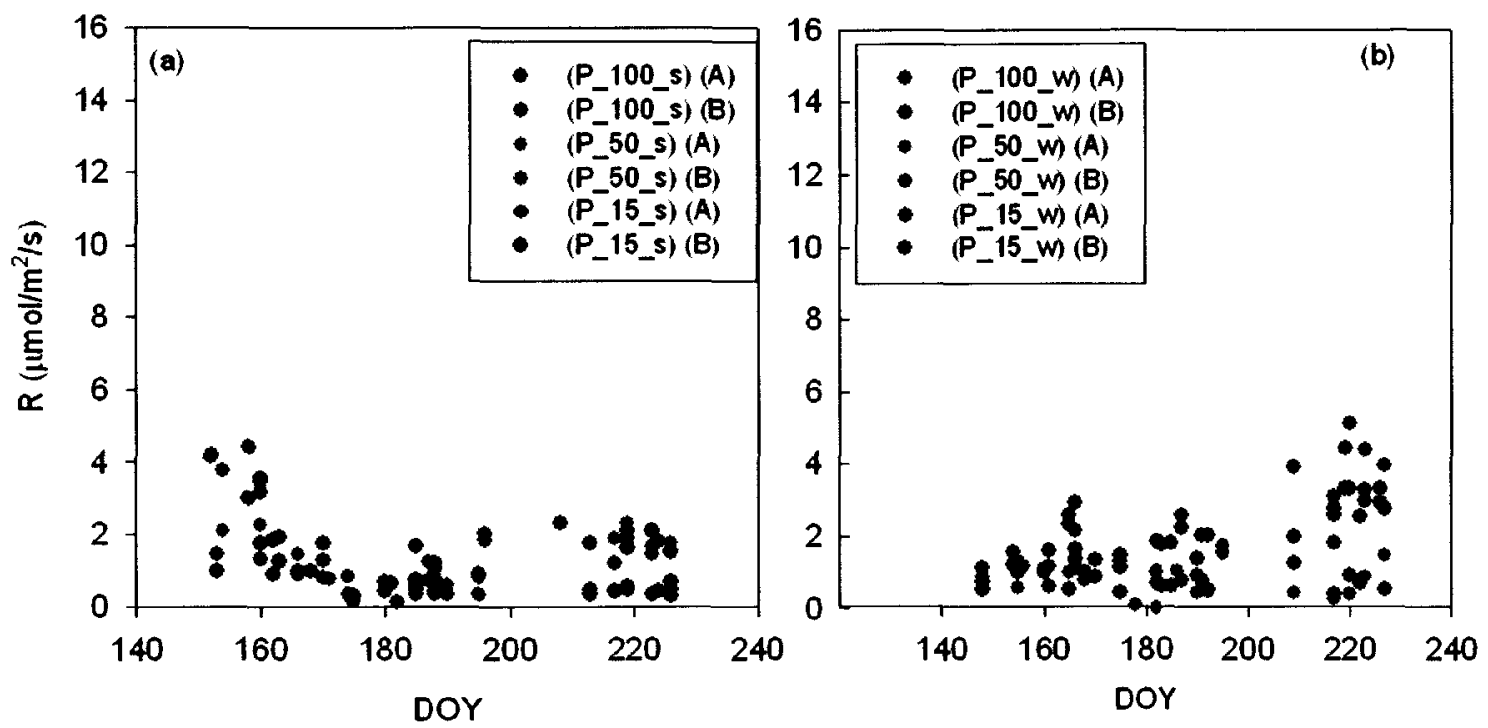

Figure 4.13: Seasonal trends in $\mathrm{R}$ for peat mix treatments with no compaction summer (a) and winter (b) during the growing season of 2009.
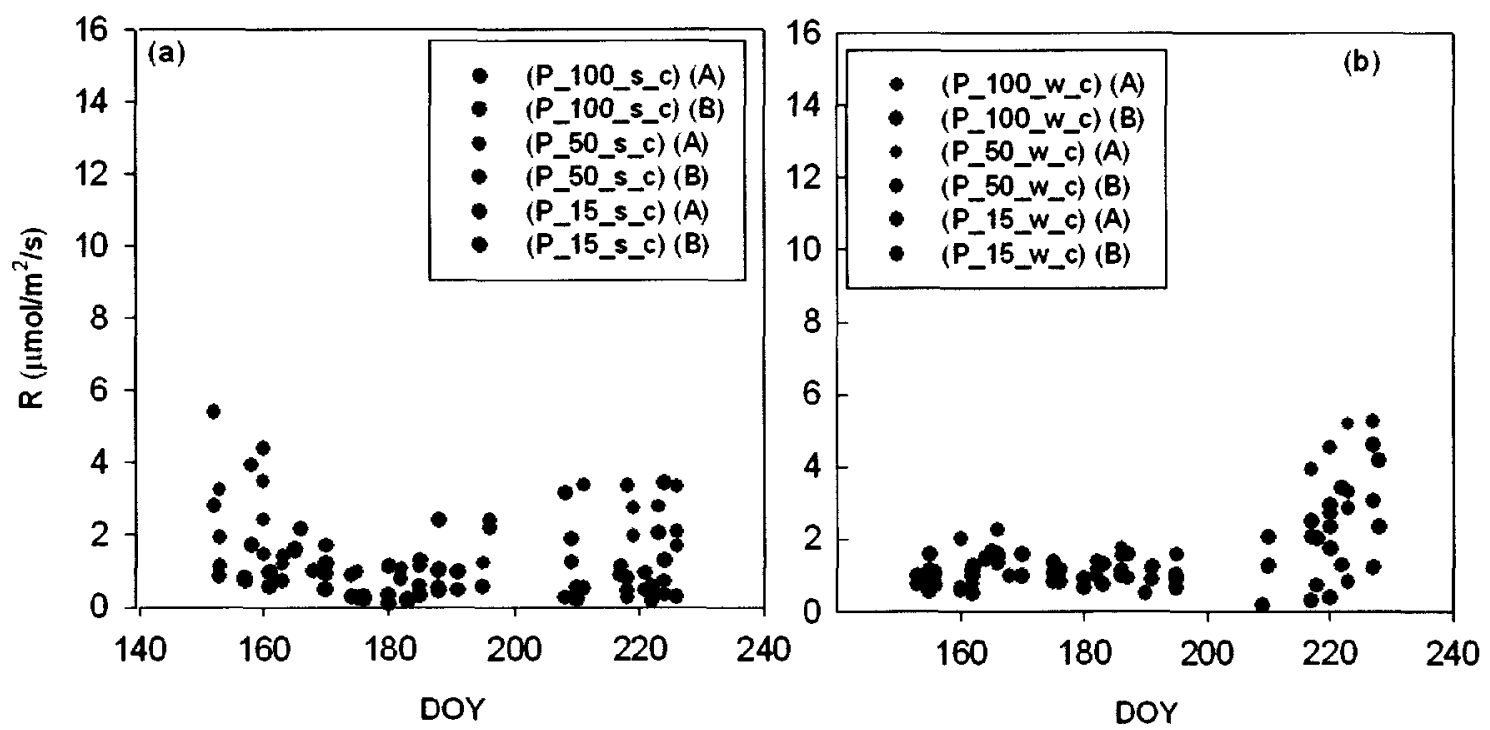

Figure 4.14: Seasonal trends in $\mathrm{R}$ for peat mix treatments with compaction summer (a) and winter (b) during the growing season of 2009. 


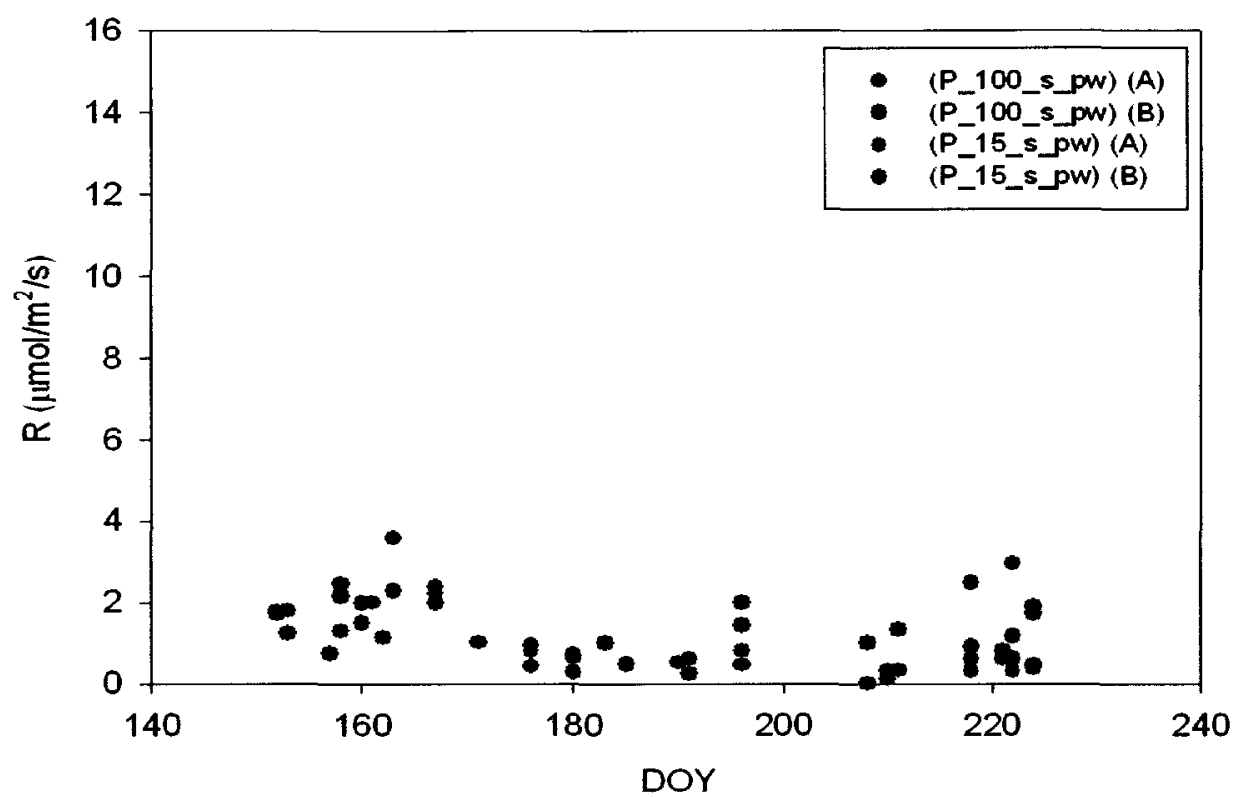

Figure 4.15: Seasonal trends in $\mathrm{R}$ for peat mix treatments with mine water during the growing season of 2009.

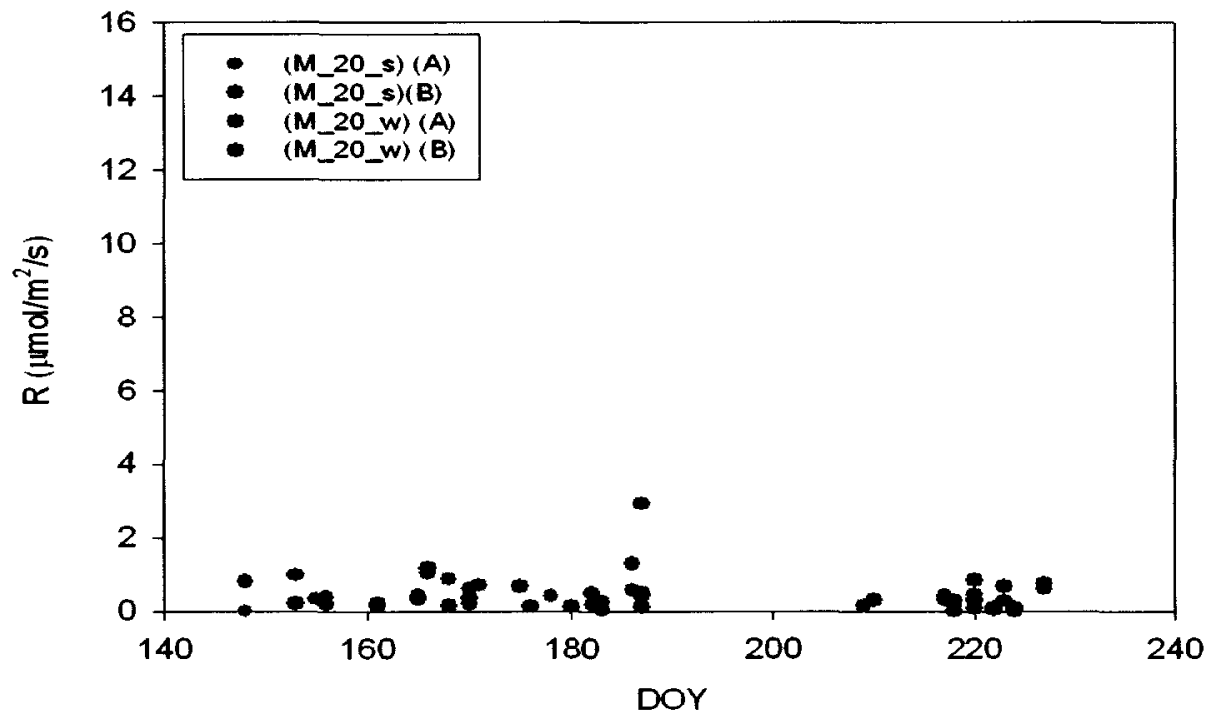

Figure 4.16: Seasonal trends in $\mathrm{R}$ for mineral soil treatments during the growing season of 2009 . 


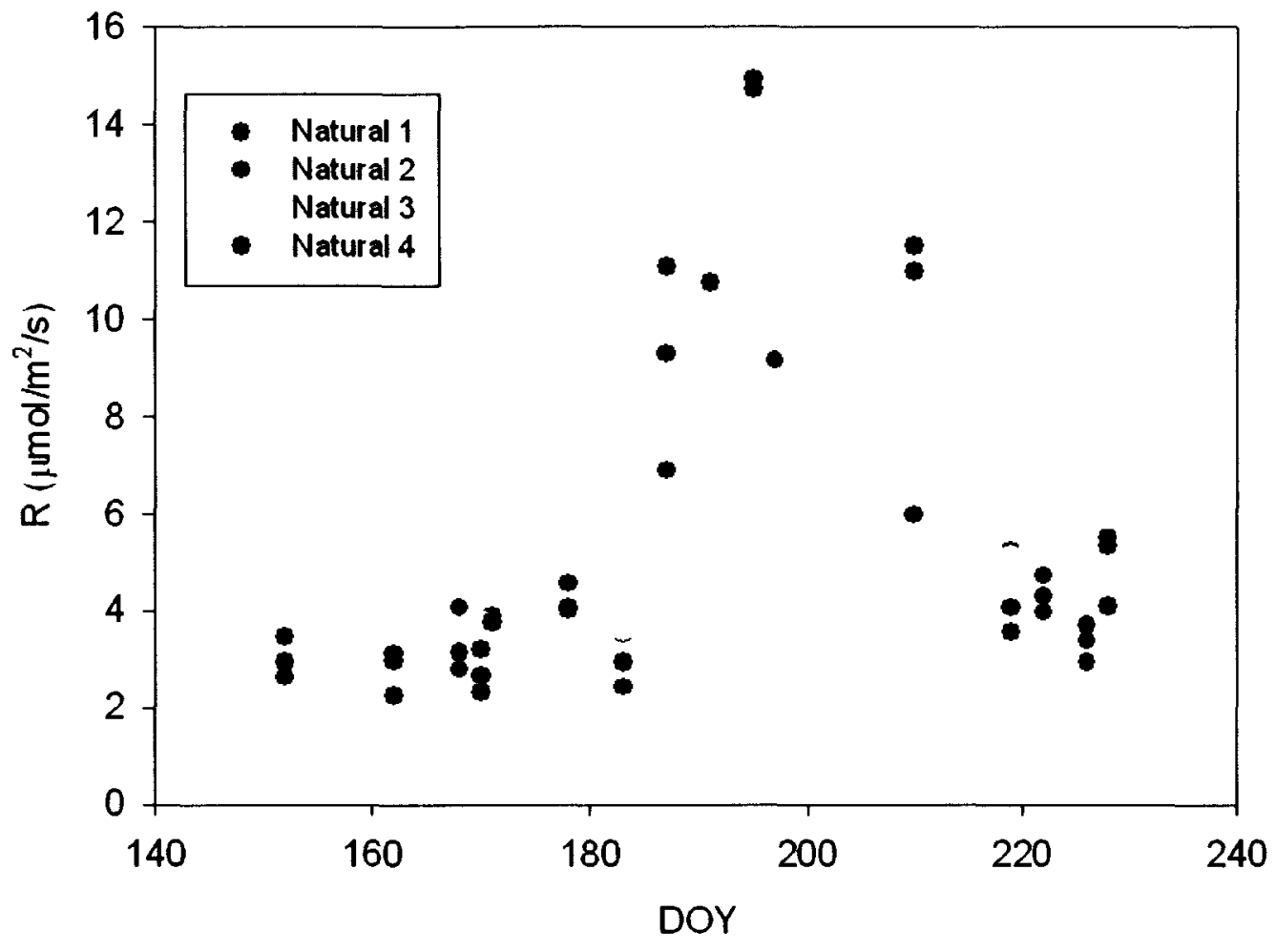

Figure 4.17: Seasonal trends in R for natural sites during the growing season of 2009. 
Table 4.8: Average measured $\mathrm{R} \pm$ standard deviation for each of the different treatments during early (ES), mid (MS), late (LS) and full growing season.

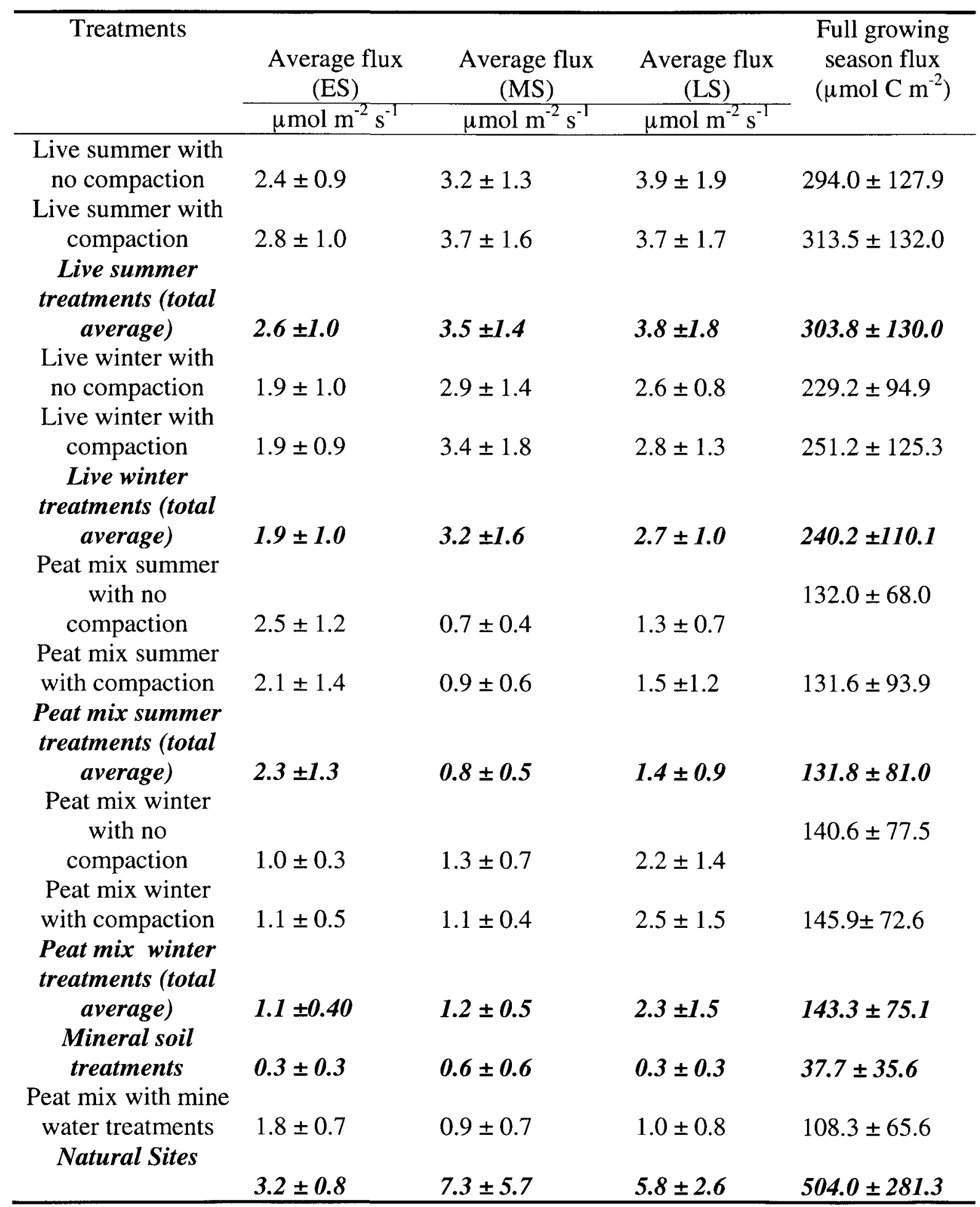




\subsection{Seasonal NEE trend for 2009 growing season}

In general, most cells became daytime sinks for $\mathrm{CO}_{2}$ (NEE became more negative) as the season progressed. The live winter treatments were the only exceptions to this trend, as they remained a source of $\mathrm{CO}_{2}$ during the majority of the season. Live treatments with compaction had less $\mathrm{CO}_{2}$ uptake when compared to non-compacted treatments. However, for peat mix summer treatments had greater $\mathrm{CO}_{2}$ uptake for the compacted treatments than the non-compacted cells but for peat mix winter treatments opposite trend was noticed. During the growing season peat depth does not had any consistent effect on the magnitude of NEE. In general, live treatments acted as a source of $\mathrm{CO}_{2}$ during the growing season. On the other side, peat mix treatments behaved mainly as a sink of $\mathrm{CO}_{2}$ during the growing season. Summer treatments were observed to be lesser source of $\mathrm{CO}_{2}$ than winter treatments for the live treatments. However, for the peat mix treatments, winter treatments were observed to be considerable greater $\mathrm{CO}_{2}$ sink than the summer treatments. In terms of NEE variability, peat mix treatments were observed to be more variable than the live treatments cells (Table 4.9). Mineral soil treatment also remained a source of $\mathrm{CO}_{2}$ for majority the season. When compared to U-shaped treatments, natural sites were unique as these were the only sites among all the treatments that acted as a sink during early summer period. The NEE data was highly scattered for the natural sites during the growing season (Figure 4.24). However, after the early growing season, on average, the natural sites were $\mathrm{CO}_{2}$ sources and although there was no particular seasonal trend. There was considerable day-to-day and collar-to-collar variability during the growing season. 
Among the U-shaped cells, some of the more notable differences in NEE are (Table 4.9):

1. Live summer treatments acted as a source of $\mathrm{CO}_{2}$ for majority of the season, however, towards the end of the growing season, these cells began to act as a sink. Meanwhile, live winter treatments acted as a source for full growing season with only two exceptions. Live winter treatments acted as a greater source of $\mathrm{CO}_{2}$ during the growing season than live summer treatments. Variability in NEE for the live winter treatments was observed to decrease with the progression of the season and during the growing season it has lower variability than live summer treatments (Figure 4.18-4.19 and Table 4.9).

2. (L_15_w) and $\left(\mathrm{L}_{-} 15 \_w \_c\right)(B)$ were the only cells among live winter treatments, which acted as a sink for $\mathrm{CO}_{2}$ on DOY 182 and DOY 223 respectively (Figure 4.18 and 4.19).

3. Peat mix with mine water acted as a sink starting from the mid-summer season. Cell (P_100_s_pw) (A) was acted as the greatest sink among all the peat mix with mine water and recorded the highest negative NEE of $-4.1 \mu \mathrm{mol} \mathrm{m} \mathrm{m}^{-2} \mathrm{~s}^{-1}$ was on DOY 222 (Figure 4.22).

4. Majority of the peat mix treatments acted as a sink of $\mathrm{CO}_{2}$ when averaged over three seasons. However, cells (P_100_s_c) (A), (P_50_s_c) (B) and (P_100_s) (A) had positive NEE for the majority of the summer season and only at few occasions, negative values were recorded. Similarly, cells (P_50_w) (A) and $\left(\mathrm{P} \_15 \_w\right)(\mathrm{A})$ were the exceptions among the peat mix winter treatments trend, as they acted as a source during full growing season. Peat mix winter treatments were considerable greater sink for $\mathrm{CO}_{2}$ and also had higher variability during the 
growing season than peat mix summer treatments (Figure 4.20-4.21 and Table 4.9).

5. Mineral soil treatments acted mainly as a sink of $\mathrm{CO}_{2}$ during the growing season. Among all the mineral soil treatment, cells (M_20_w) (B) acted as a greatest sink and recorded the highest negative NEE of $-2.1 \mu \mathrm{mol} \mathrm{m}^{-2} \mathrm{~s}^{-1}$ on DOY 217 (Figure 4.23). 

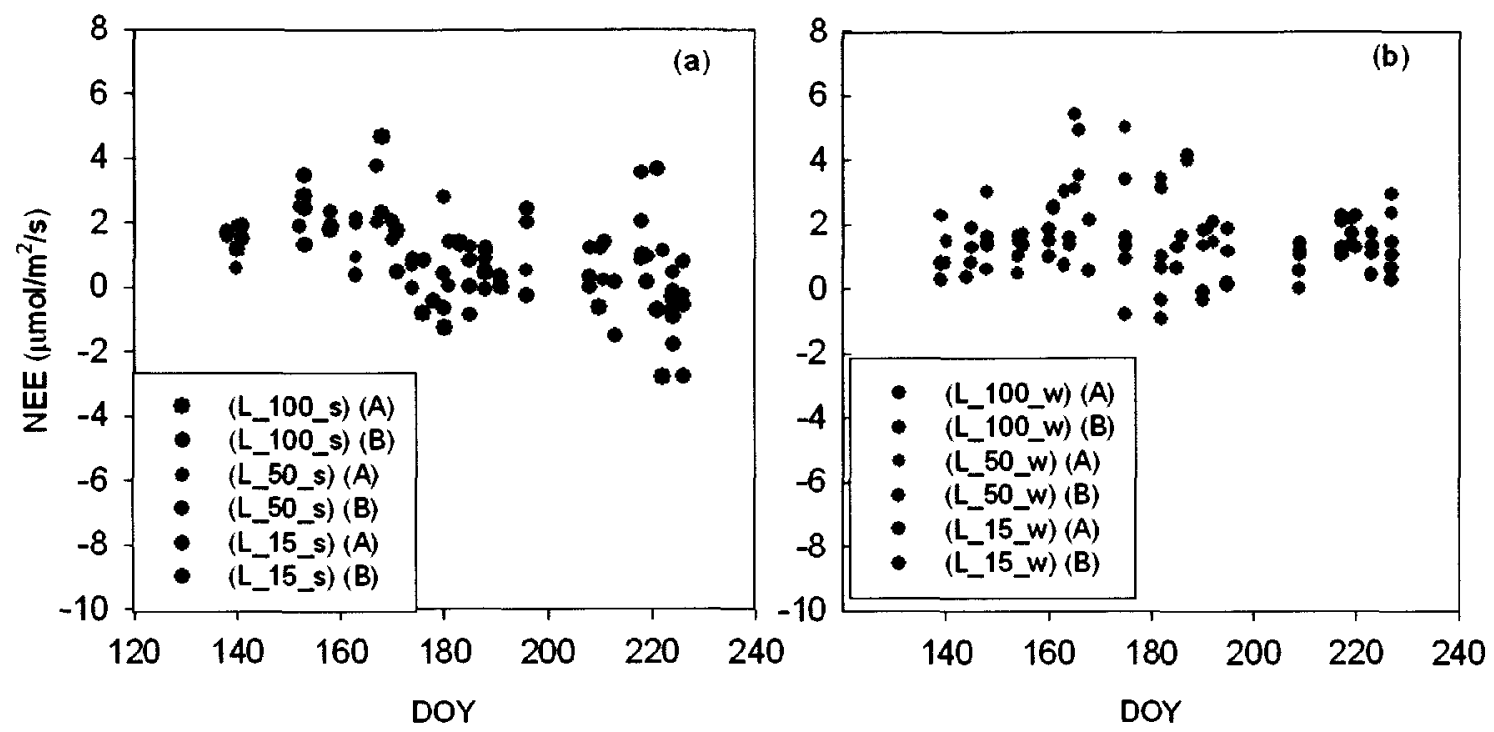

Figure 4.18: Seasonal trends in NEE for live treatments with no compaction for summer (a) and winter (b) treatments during the growing season of 2009.
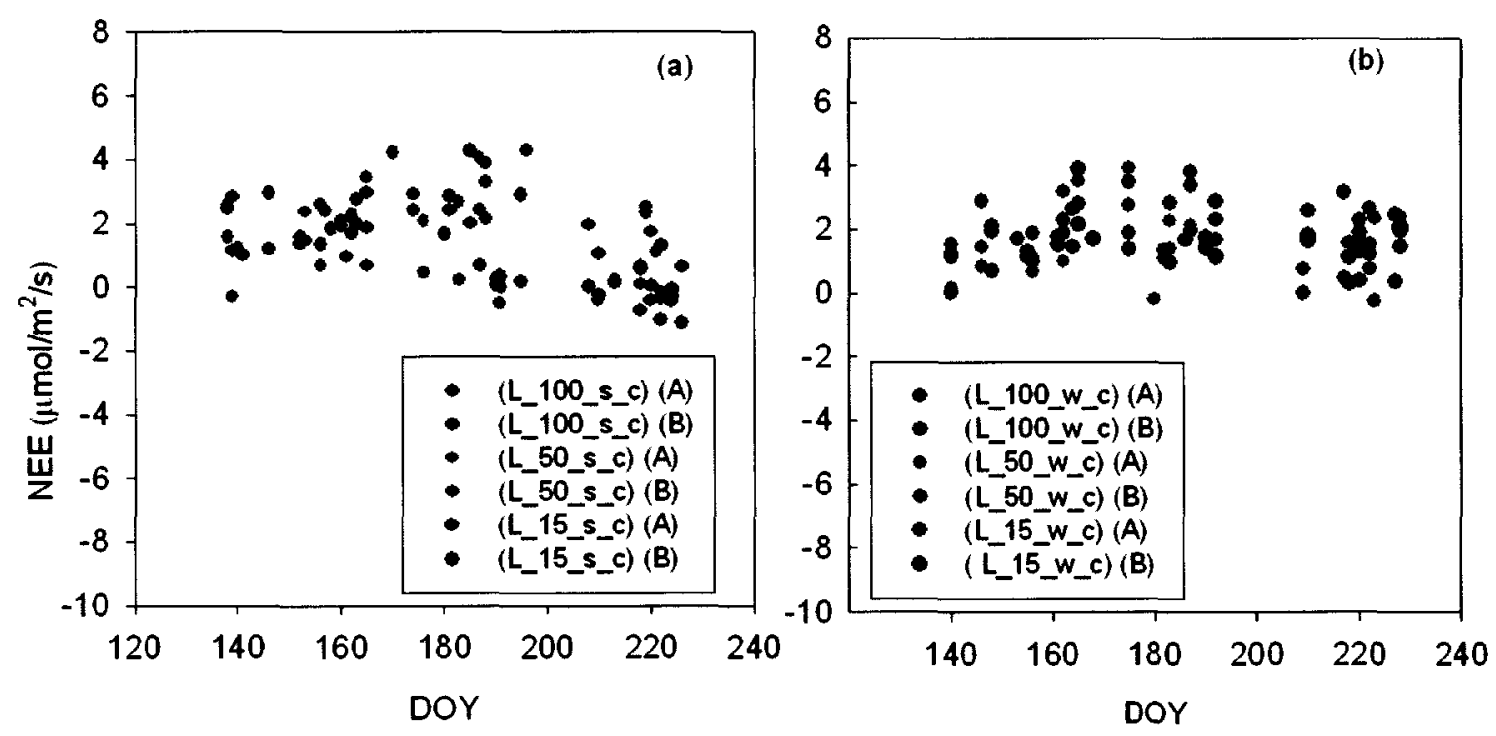

Figure 4.19: Seasonal trends in NEE for live treatments with compaction summer (a) and winter (b) during the growing season of 2009. 

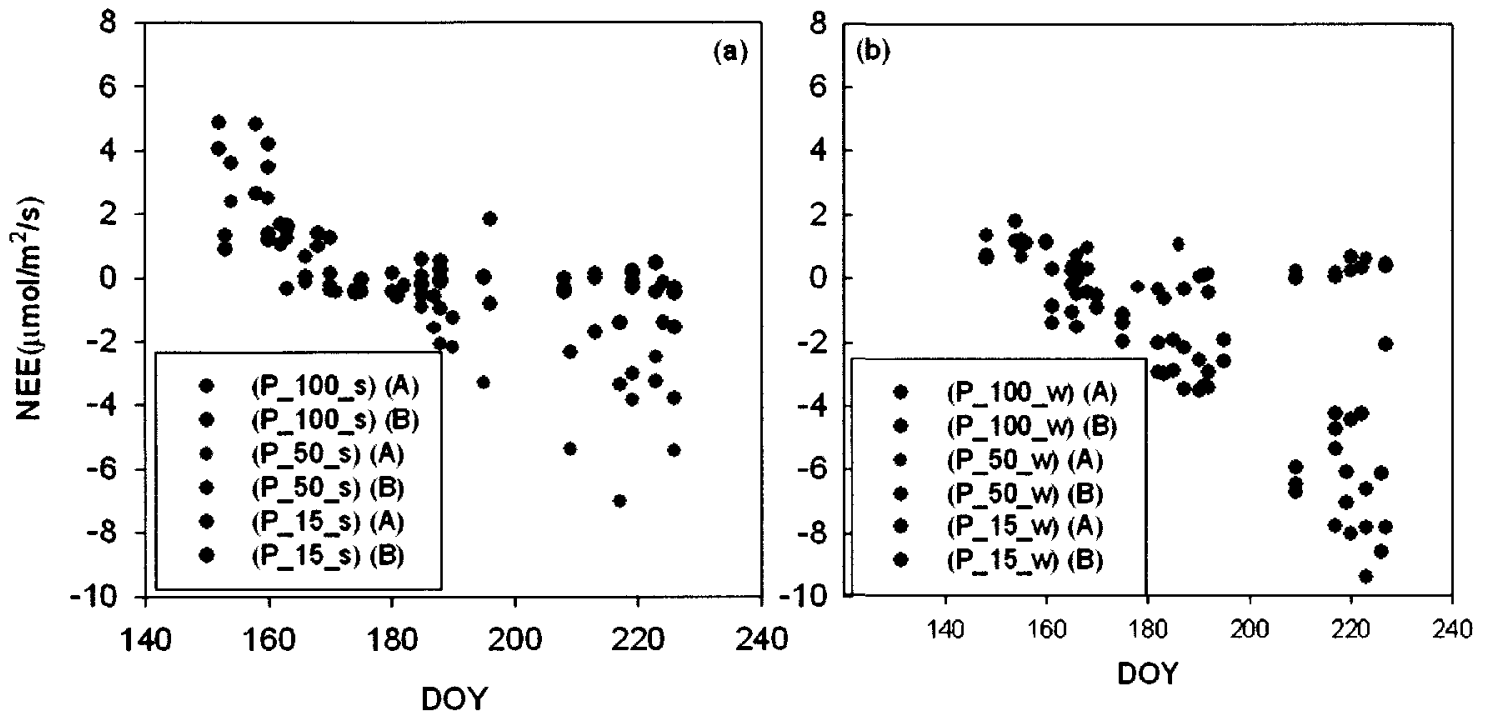

Figure 4.20: Seasonal trends in NEE for peat mix treatments with no compaction for summer (a) and winter (b) during the growing season of 2009.
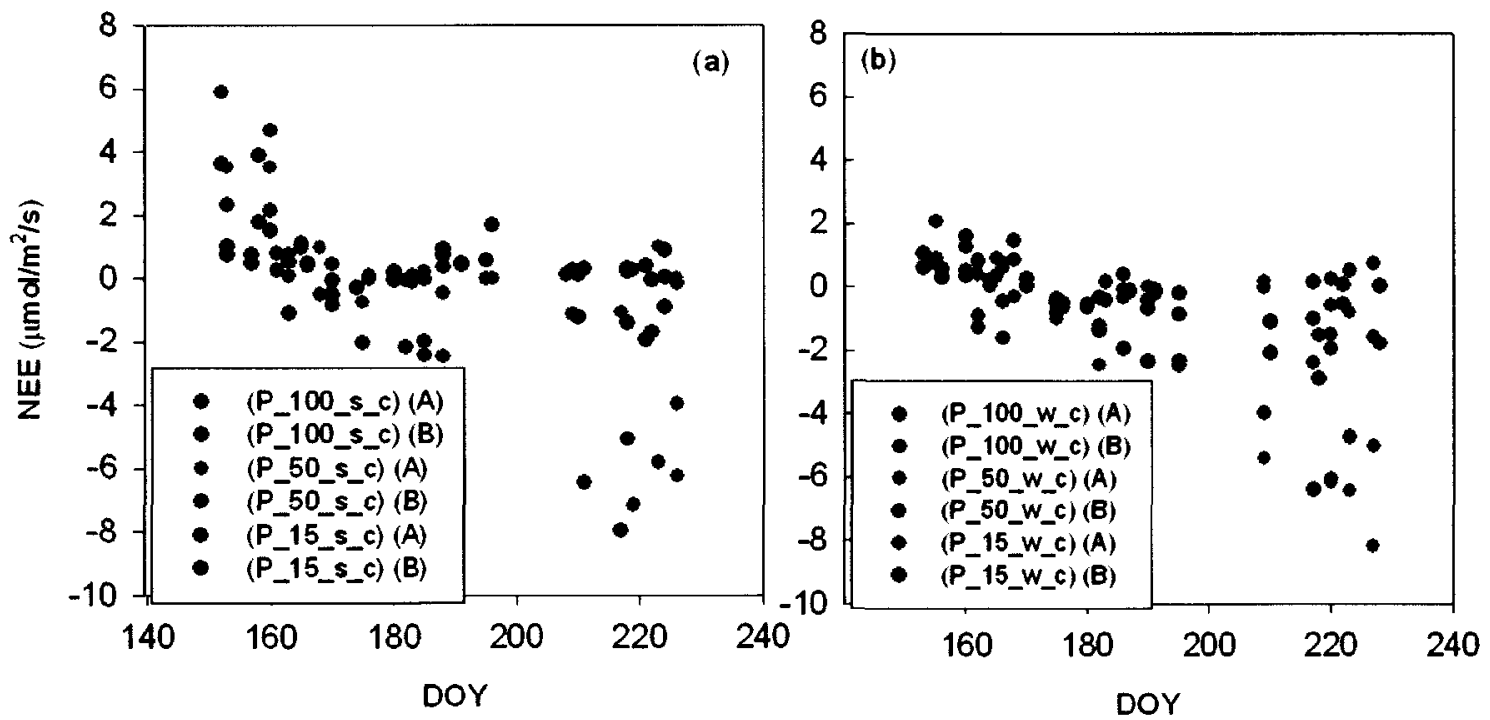

Figure 4.21: Seasonal trends in NEE for peat mix treatments with compaction for summer (a) and winter (b) during the growing season of 2009. 


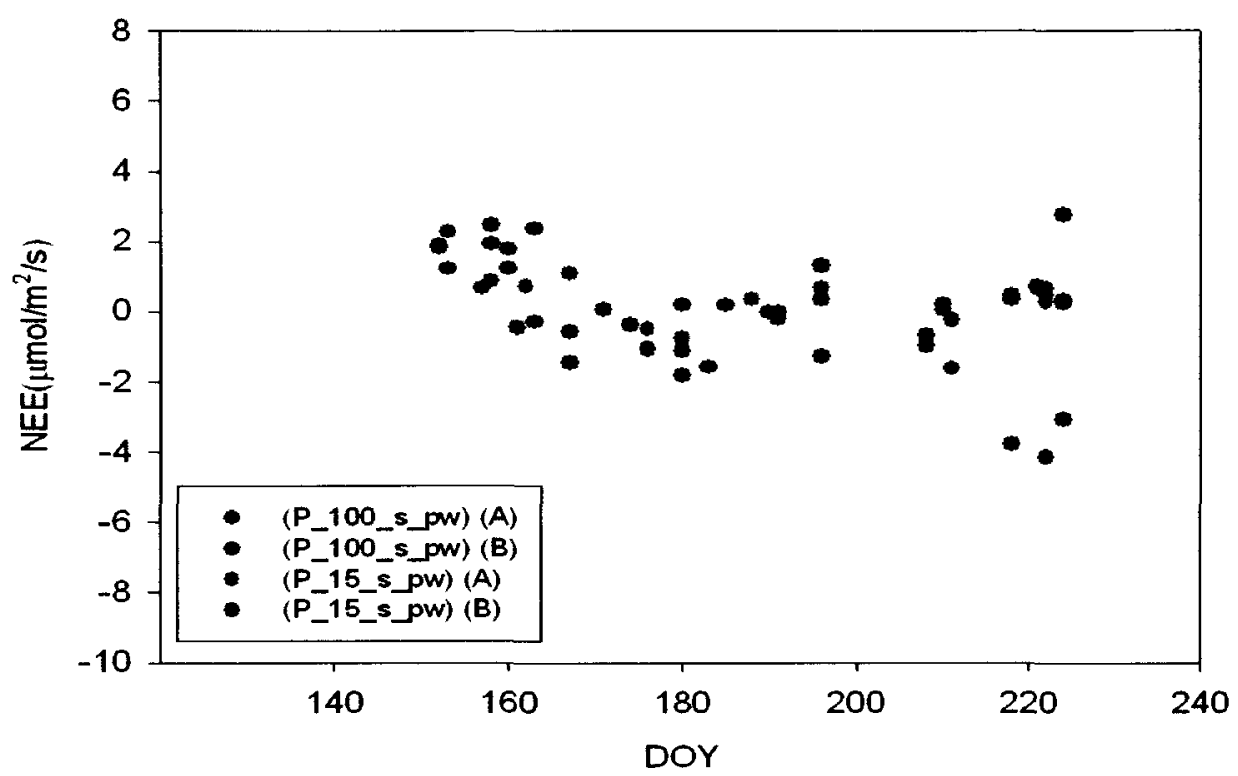

Figure 4.22: Seasonal trends in NEE for peat mix treatments with mine water during the growing season of 2009 .

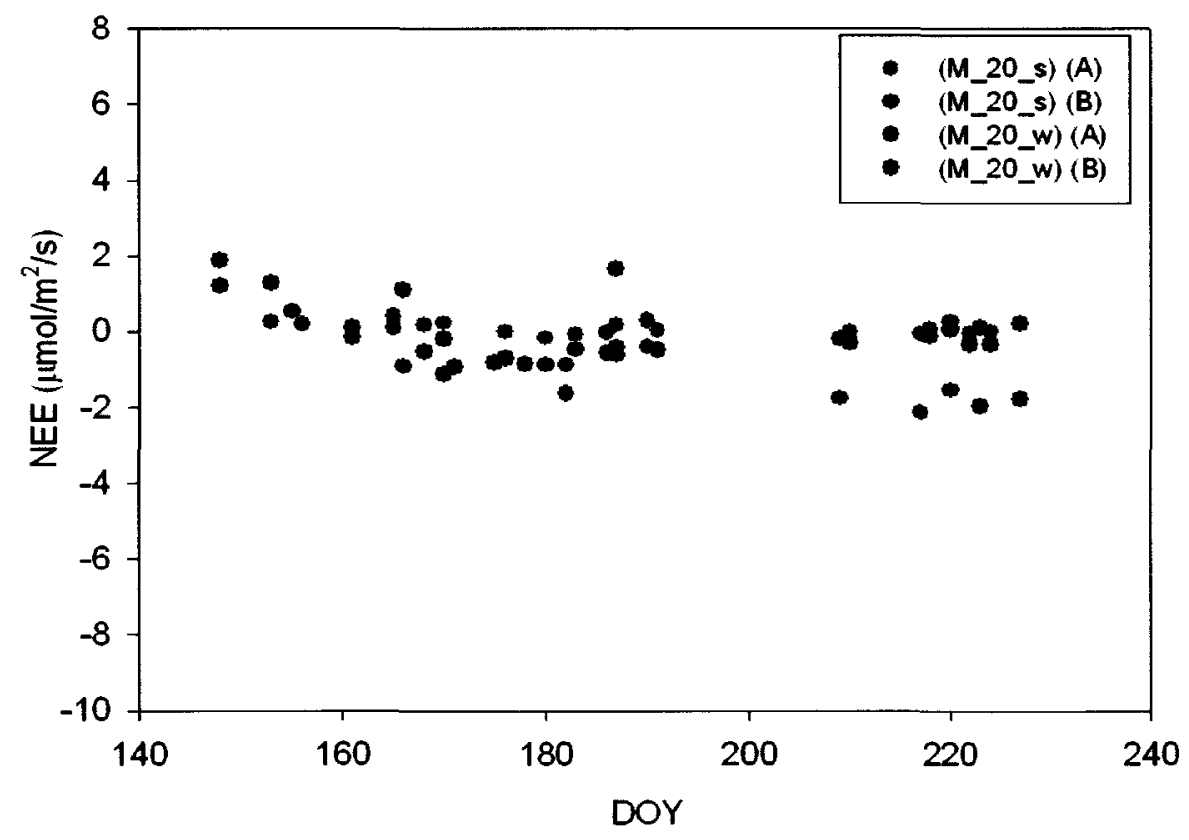

Figure 4.23: Seasonal trends in NEE for mineral soil treatments during the growing season of 2009 


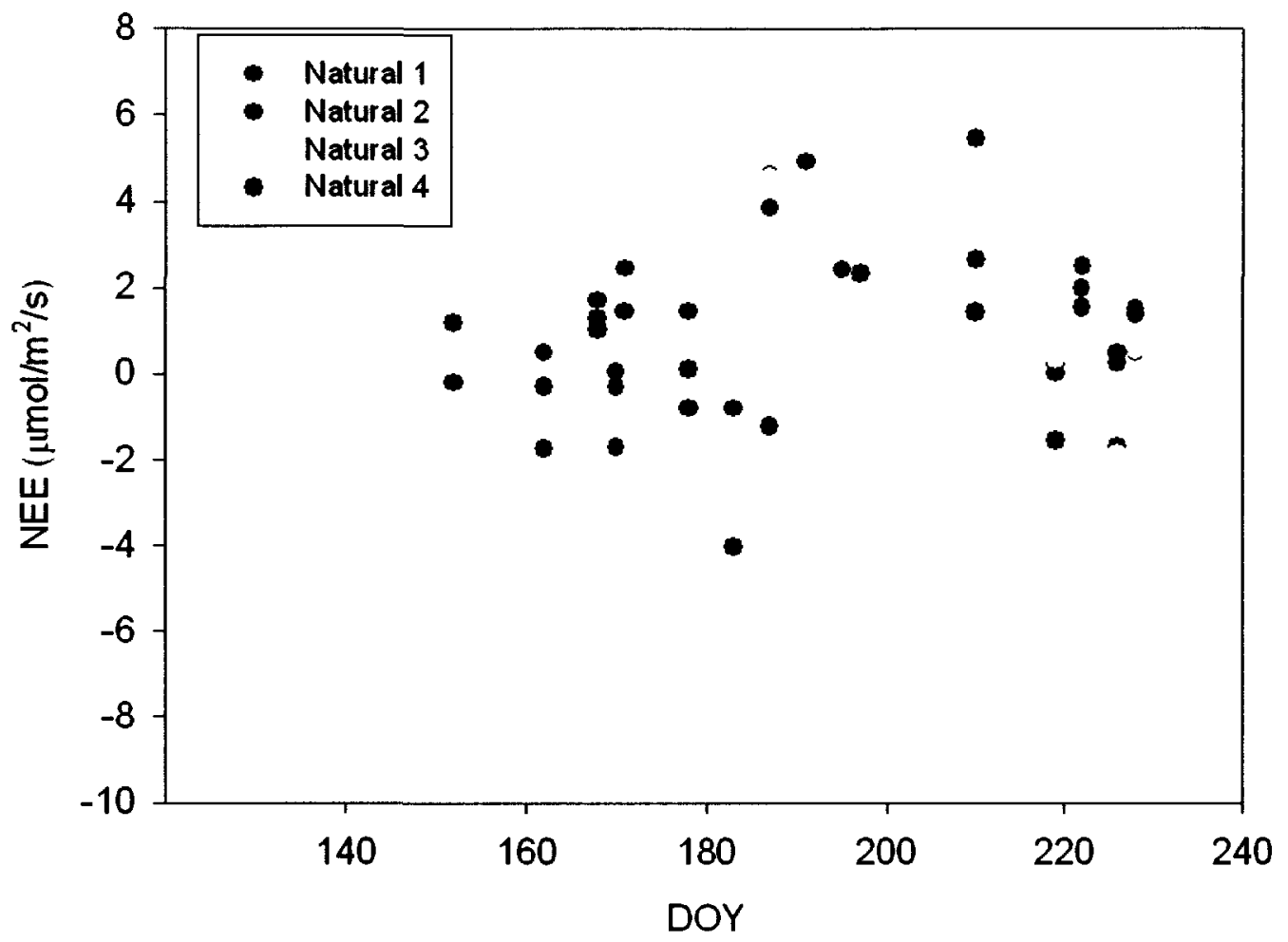

Figure 4.24: Seasonal trends in NEE for natural sites during the growing season of 2009. 
Table 4.9: Average measured NEE \pm standard deviation for each of the different treatments during early (ES), mid (MS), late (LS) and full growing season.

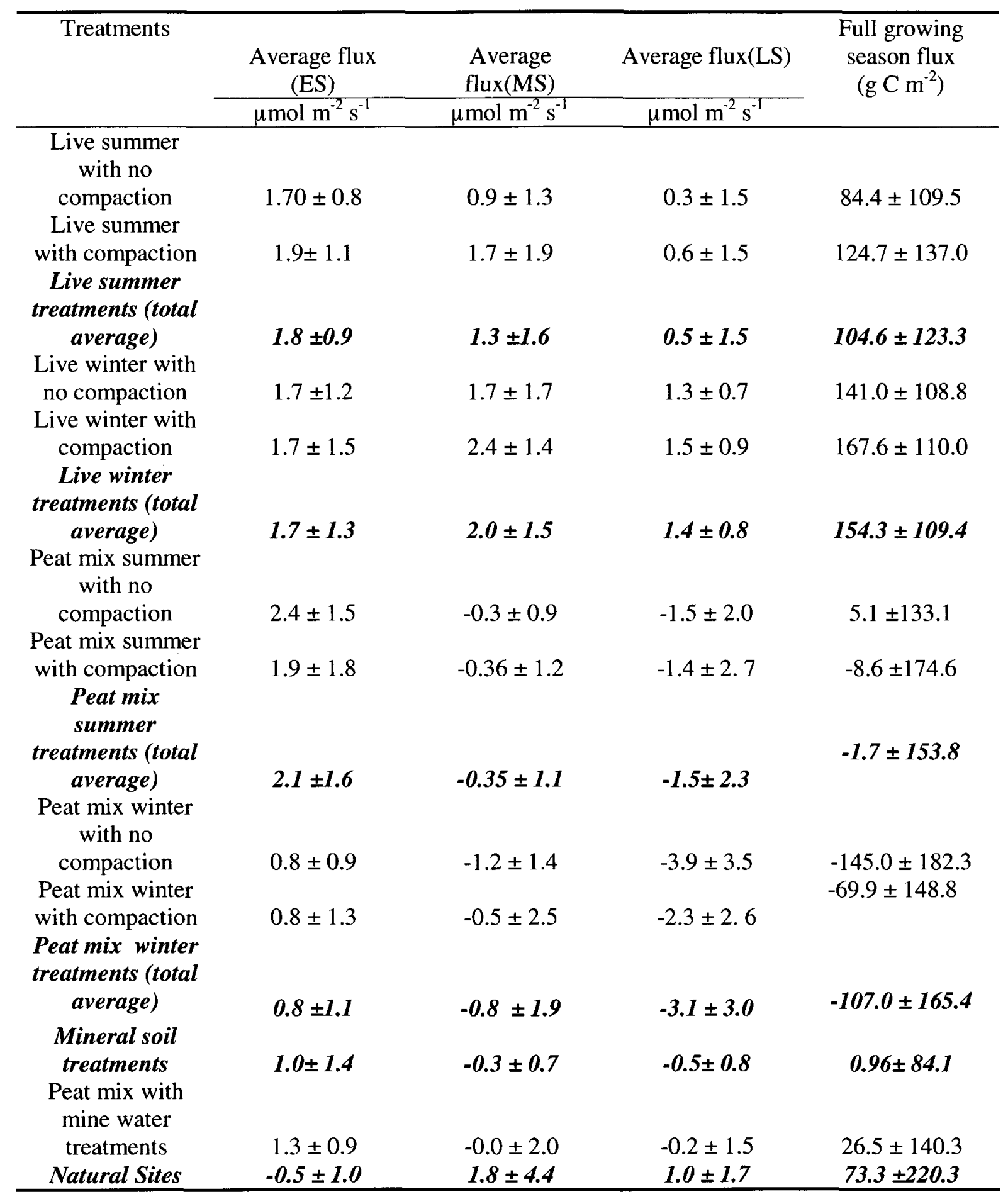




\subsection{Seasonal $\mathrm{CH}_{4}$ trend for 2009 growing season}

Methane fluxes were very small for all treatments (Table 4.10). There were negligible seasonal trends despite the increasingly anaerobic conditions and increasing soil temperatures in the cell treatments. The natural sites, the treatment with the lowest VWC, did show the highest rates of $\mathrm{CH}_{4}$ uptake during the growing season but also did not show any seasonal trends. 
Table 4.10: Average growing season $\mathrm{CH}_{4}$ flux with standard deviation for different treatments.

\begin{tabular}{ll}
\hline Treatments & $\begin{array}{l}\text { Methane flux } \\
\left(\mathrm{nmol} \mathrm{m} \mathrm{s}^{-1}\right)\end{array}$ \\
\hline Live summer treatments with no compaction & $0.0 \pm 0.7$ \\
Live summer treatments with compaction & $0.6 \pm 1.3$ \\
Live winter treatments with no compaction & $0.2 \pm 0.8$ \\
Live winter treatments with compaction & $0.1 \pm 0.8$ \\
Peat mix summer treatments with no compaction & $0.4 \pm 0.8$ \\
Peat mix summer treatments with compaction & $0.6 \pm 1.4$ \\
Peat mix winter treatments with no compaction & $0.2 \pm 0.9$ \\
Peat mix winter treatments with compaction & $0.1 \pm 0.9$ \\
Peat mix treatments with mine water & $-0.2 \pm 0.7$ \\
Mineral soil treatments & $0.1 \pm 0.7$ \\
Natural site & $-1.6 \pm 1.2$ \\
\hline
\end{tabular}




\subsection{Discussion}

\subsection{Controls on GEP, $R$ and NEE at $U$-shaped cells}

Soil moisture, soil surface temperature and LAI played an important role for the majority of the treatments in controlling the NEE, GEP and R as identified in previous studies (e.g. Waddington et al. 2010; Holden et al. 2005; Waddington and Warner 2001; Bubier et al. 1998). During the early summer, lower LAI resulted in reduced photosynthesis. At this time, all treatments acted as a net source for $\mathrm{CO}_{2}$, except for the natural site (Table 4.9). At the natural sites, the comparatively higher LAI during early summer resulted in greater GEP that exceeded R. Also, lower surface temperature during the early summer period reduced $R$ at the natural sites (Table 4.8). Meanwhile, the peat mix treatments had higher $\mathrm{R}$ during the early summer period compared to later in the season, most likely due to lower VWC. Lower VWC increases the zone of aerobic respiration, resulting in higher decomposition rates (Komulainen et al. 1999; Tuittila et al. 1999; Waddington and Warner 2001). In contrast, during early summer, peat mix winter treatments had high VWC and saturated conditions decreased aerobic respiration and suppressed $\mathrm{CO}_{2}$ emissions.

As the season progressed, the NEE decreased (i.e. $\mathrm{CO}_{2}$ uptake increased), and by mid-summer majority of the treatments began acting as a sink for $\mathrm{CO}_{2}$. The treatments which acted as the source of $\mathrm{CO}_{2}$ were live summer treatments, live winter treatments, and the natural sites as for them $\mathrm{R}$ was considerably higher than GEP (Table 4.7-Table 4.8). The increase in LAI, in part, accounted for the increase in $\mathrm{CO}_{2}$ uptake. Greater LAI provides more surface area for photosynthetic chemical reactions to occur (Nobel et al. 
1975). Watering had begun taking place consistently by mid summer at the U-shaped cells providing sufficient moisture to sustain vegetation development. This occurred in both live cells with pre-existing peatland plants and in treatments where seedlings were all planted by hand by DOY 153 . Higher VWC and water table near the surface resulted in a reduced zone for aerobic respiration, which contributed to the decreased $\mathrm{R}$ for peat mix treatments (Table 4.8). Surface temperature did not have any notable effect on $\mathbf{R}$ among the peat mix treatments such that an increase in $\mathrm{R}$ was not observed during the period with higher soil temperature. Generally, increases in surface temperature enhance the microbial activity inside the soil and result in higher $\mathbf{R}$ (Waddington et al. 2010; Waddington and Warner 2001; Holden et al. 2005). The increase in surface temperature did, however, play an important role in the case of the live summer treatments, live winter treatments, mineral soil treatments and natural sites. In the case of live winter treatments, $\mathrm{R}$ decreased during the late summer period. The decline in $\mathrm{R}$ at live winter treatments with no compaction was likely due to the high VWC. Reductions in LAI would have led to a decrease in autotrophic respiration and cooler surface temperature and higher VWC would have reduced decomposition.

The influence of soil moisture, temperature and LAI each played a different role on NEE during different times of the season. The soil moisture content played an important role during the early summer season when watering was limited. Vegetation, as quantified by changes in LAI, played an important role throughout the growing season. 


\subsection{Treatment effects on GEP, $R$ and NEE at U-shaped cells}

\subsubsection{Compaction}

In general, compaction did not result in any specific trend during the growing season for GEP. In some treatments GEP increased, however, for other treatments it decreased. For example, live summer treatments with no compaction had higher GEP than live summer treatments with compaction, but, for live winter treatments with no compaction lower GEP was observed than live winter treatments with compaction.

Generally, increase in compaction reduces GEP due to reduction in root elongation zone (Grigal 2000). However, in this study, results suggest that compaction of these highly porous soils would not have inhibited plant growth in any significant way and hence, no particular trend was noticed for GEP. In contrast, all the compacted treatments had slightly higher $\mathrm{R}$ than non-compacted treatments. The only exception to this trend was peat mix summer treatments as it had similar flux for both compacted and non-compacted treatments.

Generally, compaction directly reduces the soil pore size and this result in higher water retention and creates anaerobic conditions. Reduction in aerobic zone causes decline in respiration rates. However, a study in Alberta showed that under water logged conditions, compaction can lead to increase in decomposition rates (Pothier 2000). The presence of woody debris can provide extra food for microbial communities and can increase the rate of decomposition. It can be assumed that compacted cells in the current study may had higher woody debris than non-compacted ones and hence resulted in greater 
decomposition (Welke and Fyles 2006). Yet, this is only an assumption and at this instance exact reason behind this trend is not clear.

\subsubsection{Peat Depth}

During the growing season, peat depth does not have a clear effect on the GEP, R, and NEE. For example, for live summer treatment with no compaction, both $15 \mathrm{~cm}$ and $100 \mathrm{~cm}$ peat were observed to have greater GEP than $50 \mathrm{~cm}$ peat. Generally, shallower peat depths do not grant satisfactory conditions for plant growth as the soil dries up quickly due to higher evapotranspiration rates (Meerveld and McDonnell 2006). At deeper depths soil likely to have greater amount of substrate and microbial communities. However, at deeper depths saturated conditions result in anoxic condition which suppress aerobic respiration and $\mathrm{CO}_{2}$ efflux (Chimner 2004). However, for this study, ample water supply was available to recharge the cells on a regular basis and hence, sufficient moisture was always available for the proper growth and development of the plants, and resulting in no specific trend in between peat depth and GEP, R, and NEE.

\subsubsection{Winter vs. Summer Placement}

During the growing season, live and peat mix treatments illustrated opposite trends when placed in summer vs. winter. For the live treatments, summer placements had greater LAI and 2 times greater the GEP and slightly greater R but less positive NEE such that it was smaller source of $\mathrm{CO}_{2}$ during the growing season than the live winter placements. Greater LAI resulted in greater GEP and R during the growing season as it provides more surface area for photosynthesis (Nobel et al. 1975), as well as higher autotrophic respiration. In contrast, peat mix winter treatments had higher LAI, than the 
summer treatments, and resulted in greater GEP and $\mathrm{R}$, due to more photosynthetic activity and autotrophic respiration. In terms of NEE, GEP was much higher than the R for winter placements and these treatments were a much greater sink for $\mathrm{CO}_{2}$ than summer placements.

It can be hypothesized that live summer treatments did better than winter ones because in summer it is easy to cut and remove the peat from the natural sites. In contrast, during winter soil is frozen and hence, transplantation can results in more damage to soil structure and plants. However, for the peat mix soil, the timing of transplantation was not an issue as the soil had no structure and pre-established plantation to begin with. Therefore, it can be assumed that either winter treatments had healthier green house plants to start with or had greater number of plant species which can adapt quickly than the summer treatments.

\subsubsection{Soil type (peat mix vs. live vs. mineral)}

Mineral soil treatments had smallest GEP during the growing season, mainly due to lower LAI. Physically, mineral soils were quite hard due to dominance of clay material, and greenhouse seedlings were not able to adapt successfully as their roots were not able to penetrate the hard soil. $\mathrm{R}$ was also observed to be lowest for the mineral soil as autotrophic respiration was limited and it is likely there was limited decomposition due to a lack of oxygen and with little organic material in this soil, there was limited substrate available. Although GEP was very low, it was greater than $\mathrm{R}$ and the mineral soil treatment acted as a very small sink of $\mathrm{CO}_{2}$ by late summer but was $\mathrm{CO}_{2}$ neutral over the full summer. 
The peat mix soil was highly porous and greenhouse seedlings were able to adapt quickly. The LAI increased rapidly for peat mix treatments in comparison to other live and mineral soil treatments. Overall, during the full growing season, LAI for peat mix was lower than the live treatments. However, peat mix treatments had greater GEP than live treatments. It is not clear at this point why peat mix treatments had greater GEP than live treatments, though it may be related to the species present. Peat mix treatments had very young plants with more herbaceous and graminoid species while live treatments had older conifer trees and ericaceous shrubs that may have had less photosynthetic capacity due to age, species type and damage to root systems during the transplanting process (Cagampan and Waddington 2008). Therefore, the GEP results were a bit biased as vegetation health and species types were different from treatments to treatments. Peat mix treatments had much lower R than live treatments. Lower LAI may have resulted in smaller autotrophic respiration levels. Generally, soil respiration reflects the health of the soil, higher levels of respiration suggest that soil is healthy and properly structured (Sachs 1999). In the current study, peat mix soil respiration levels suggest that bacterial community was only partially functional, and it can take some time to develop proper soil structure and properties. However, for the live treatments, respiration levels were quite high, and suggest that the transplanted live treatments soil had healthy bacterial population and developed soil structure. It is also likely that disturbance in live treatments may further contributed in R levels. Generally, disturbance increases R, as it can effects the soil properties such as texture, porosity and changes in soil moisture (Blouin 2000). Disturbance such as clear cutting can increase the amount of litter fall, live roots etc and can lead in higher $\mathrm{CO}_{2}$ production due to increase in microbial activity (Masyagina et al. 
2006). On local scale, disturbance can provide pathways for $\mathrm{CO}_{2}$ from belowground into atmosphere. In terms, of NEE, peat mix treatments were mainly a sink for $\mathrm{CO}_{2}$ due to higher GEP and lower respiration levels while live treatments were a source for $\mathrm{CO}_{2}$ due to higher $\mathrm{R}$ than GEP throughout the growing season.

\subsection{NEE, GEP, R Comparison with Literature}

Restored sites in Cagampan and Waddington (2008) fall within the same range for GEP as live winter treatments; however, in comparison to live summer treatments it has lower GEP. In Cagampan and Waddington (2008) actotelm layer was extracted and transported over the disturbed sites located at the Pointe-Lebel peatland, which is $\sim 20$ $\mathrm{km}$ from Baie Comeau, Québec. Desiccation and death of vascular and non-vascular plants happened during the transportation of acrotelm, and although not measured, it is believed that LAI was lower than live treatments in the current study, which has resulted in lower GEP. In addition, lower R was observed in Cagampan and Waddington (2008) when compared to live treatments in this study most likely due to reduced amount of autotrophic respiration as in both studies microbial activity was limited due to higher soil moisture levels. Overall, live treatments in the current study acted as a greater source of $\mathrm{CO}_{2}$ than Cagamapan and Waddington (2008) as R dominated the GEP during the growing season in the current study.

In another study by Waddington et al. (2010), the GEP was observed to higher than live treatments in this study. The GEP for Waddington et al. (2010) was slightly higher than the live summer treatments, but, was almost four times greater than the live winter treatments. Waddington et al. (2010) restored sites at Boes-des-Bel, Quebec is 
likely to have higher LAI than the live treatments as no transplantation of acrotelm occurred, which can decrease the negatively impacts LAI. Also, dominance of herbaceous and moss vegetation at the restored sites suggests the possibility of higher LAI than the live treatments in this study.

Waddington et al. (2010) had lower $\mathrm{R}$ than the live treatments in this thesis even though average VWC during the study years was only $50 \%$. Therefore, smaller respiration levels under lower soil moisture suggest that microbial activity must be limited. This may be due to lack of electron acceptors in the soil, which are required to prompt $\mathrm{CO}_{2}$ production. $\mathrm{R}$ in Waddington et al (2010) also suggests that soil may not have been properly developed and structured. The NEE in current study and Waddington et al. (2010) were observed to fell in similar as it is dependent on both GEP and R.

In comparison to natural boreal bogs, the live summer and winter treatments in this thesis acted as a greater source of $\mathrm{CO}_{2}$ (Table 5.1) (Cagampan and Waddington 2008; Bubier et al. 2003; Bellisario and Moore 1998; Bubier et al. 1998). As a result of lower LAI during the growing season, live summer and winter treatments had lower photosynthetic activity, and hence lower GEP than natural boreal bogs sites (Cagampan and Waddington 2008; Bubier et al. 2003; Bellisario and Moore 1998; Bubier et al. 1998). The $\mathrm{R}$ at the live treatments was observed to be greater than the majority of the natural boreal bogs sites presumable due to lower soil moisture during the early season and also due to higher disturbance along with increased surface temperature during mid and late summer season. Bellisario and Moore (1998) measured fluxes at a peatland comprised of both bog and fen with dominant vegetation of Carex and Sphagnum near Thompson Manitoba. Bellisario and Moore (1998) recorded about two times less R than 
observed for live treatments in this thesis. Dominance of Sphagnum in Bellisario and Moore (1998) must have resulted in lower autotrophic respiration than that of live treatments in the current study. Also, lack of disturbance in the study by Bellisario and Moore (1998) sites may be responsible for lower R. However, lower water table depth in the natural sites near Baie Comeau, Quebec (Cagampan and Waddington 2008) and at a natural sites located near Thompson, Manitoba (Bubier et al. 1998) had similar R as the live summer and winter treatments in this study. In Contrast, $\mathrm{R}$ at Mer Bleue, which is an Ombrotrophic bog located at Mer Bleue, near Ottawa, Ontario, had two to three times greater $\mathrm{R}$ than live summer and winter treatments, presumably due to greater autotrophic respiration and decomposition rates due to a lower water table (Lafleur et al. 2009; Bubier et al. 2003).

Overall, greater R and lower GEP made live treatments a greater source of $\mathrm{CO}_{2}$ during the 2009 growing season at U-shaped cells. The natural sites in this thesis were also a greater source of $\mathrm{CO}_{2}$, in comparison to natural sites described by Cagampan and Waddington (2008) and Bellisario and Moore (1998). The natural sites in this thesis have been previously drained; and in comparison to other natural boreal bogs sites they had lower soil moisture levels, resulting in higher R (Cagampan and Waddington 2008; Bellisario and Moore 1998).

Peat mix summer and winter treatments average daily GEP was observed to be lower than natural boreal bogs sites (Cagampan and Waddington 2008; Bubier et al. 2003; Bubier et al. 1998; Bellisario and Moore 1998). The LAI for peat mix treatments was considerably lower than the natural boreal bogs sites and was responsible for overall lower GEP during the growing season. The reason for lower LAI for peat mix treatments 
than natural boreal bogs sites was mainly due to the fact that they had no vegetation at the start of the study. Vegetation was transplanted from greenhouses and planted on these treatments during the early summer period. Increase in LAI through the growing season was a result of the growth of both natural and invasive vegetation, and therefore fluctuations in LAI during the growing season resulted in greater range in GEP. However, for the peat mix treatments with mine water GEP was considerable lower than natural bog sites. High salt content in the mine water resulted in the death of vegetation in the majority of the collars and resulted in considerably lower GEP than any of the natural boreal bogs sites (Cagampan and Waddington 2008; Bubier et al. 2003; Bubier et al. 1998; Bellisario and Moore 1998).

With respect to $\mathrm{R}$, peat mix treatments, and peat mix treatments with mine water had lower flux than the natural boreal bogs sites. Natural boreal bog sites had lower VWC and greater LAI during the growing season. Therefore, a greater zone of aerobic respiration and higher autotrophic respiration is likely to be responsible for higher $\mathrm{R}$ at the natural boreal bogs.

Hence, lower $\mathrm{R}$ at peat mix treatments and peat mix treatments with mine water offsets the differences in GEP and allowed them to have NEE in similar range as natural boreal bogs (Cagampan and Waddington 2008; Bellisario and Moore 1998). In contrast, Bubier et al. 2003, sites acted as a greater sink of $\mathrm{CO}_{2}$ than peat mix treatments.

When compared with the restored sites in other studies, the peat mix treatments in this study acted as a more effective carbon sink for majority of the growing season due to lower R and higher GEP (Waddington et al. 2010; Cagampan and Waddington 2008). 
The average daily GEP and R for the mineral soil treatments was observed to be much lower than the natural boreal bogs and restored sites (Waddington et al. 2010; Cagampan and Waddington 2008; Waddington and Warner 2001; Bubier et al. 1998; Bellisario and Moore 1998). LAI at the mineral soil treatments was substantially lower in comparison to the natural boreal bogs sites and restored sites, which resulted in lower GEP and R. The mineral soil treatments were quite rich in clay, and that resulted in hard soil. The roots of transplanted green house vegetation were not able to penetrate or adapt successfully. Also, small soil particles and texture resulted in higher water retention, as a result lower soil and autotrophic respiration resulted in lower $\mathrm{R}$ than peat mix treatments. No fertilization was applied to any of the treatments during the study year, and it made harder for mineral soil vegetation adapt effectively in comparison to organic soils. 
Table 5.1: Comparison of the range in of observed NEE, GEP, and R in this study and with previous literature on restored and natural bogs based on similar DOY criteria used for the current study. In some studies values were reported in $\mathrm{g} \mathrm{CO}_{2} \mathrm{~m}^{-2} \mathrm{day}^{-1}$ and hence they were converted into $\mu \mathrm{mol} \mathrm{m} \mathrm{m}^{-2}$. However, original values in $\mathrm{g} \mathrm{CO}_{2} \mathrm{~m}^{-2} \mathrm{day}^{-1}$ were also reported inside the bracket.

\begin{tabular}{|c|c|c|c|}
\hline Treatments & $\begin{array}{l}\mathrm{NEE} \\
\left(\mu \mathrm{mol} \mathrm{m} \mathrm{m}^{-1}\right)\end{array}$ & $\begin{array}{l}\text { GEP } \\
\left(\mu \mathrm{mol} \mathrm{m}{ }^{-2} \mathrm{~s}^{-1}\right)\end{array}$ & $\begin{array}{l}\mathrm{R} \\
\left(\mu \mathrm{mol} \mathrm{m} \mathrm{m}^{-2} \mathrm{~s}^{-1}\right)\end{array}$ \\
\hline live summer treatments & 0.5 to 1.8 & 1 to 3.3 & 2.6 to 3.8 \\
\hline live winter treatments & 1.4 to 2.0 & 0.6 to 1.3 & 1.9 to 3.2 \\
\hline Peat mix summer treatments & -1.5 to 2.4 & 0.4 to 2.8 & 0.8 to 2.3 \\
\hline Peat mix winter treatments & -3.1 to 0.8 & 0.8 to 5.5 & 1.1 to 2.3 \\
\hline Mineral soil treatment & -0.5 to 1.0 & 0.3 to 0.9 & 0.3 to 0.6 \\
\hline $\begin{array}{l}\text { Peat mix with mine water } \\
\text { treatments }\end{array}$ & -0.2 to 1.3 & 1 to 1.5 & 0.9 to 1.8 \\
\hline natural sites & -0.5 to 1.8 & 3.8 to 5.8 & 3.2 to 7.3 \\
\hline $\begin{array}{l}\text { Waddington et al (2010) } \\
\text { (restored site) }\end{array}$ & $\begin{array}{l}0.8 \text { to } 2.2 \\
(2.9 \text { to } 8.3)\end{array}$ & $\begin{array}{l}2.8 \text { to } 4.6 \\
\text { (10.5 to } 17.3)\end{array}$ & $\begin{array}{l}1.3 \text { to } 3.0 \\
(4.9 \text { to } 11.2)\end{array}$ \\
\hline $\begin{array}{l}\text { Waddington and Warner } \\
(2001) \text { (restored site) }\end{array}$ & N/A & $3.7(13.9)$ & $1.1(4.3)$ \\
\hline $\begin{array}{l}\text { Cagampan and Waddington } \\
\text { (2008) (restored site) }\end{array}$ & $\begin{array}{l}0.3 \text { to } 0.4 \\
(1 \text { to } 1.5)\end{array}$ & $\begin{array}{l}0.8 \text { to } 1.3 \\
\text { ( } 3 \text { to } 5 \text { ) }\end{array}$ & $\begin{array}{l}1.1 \text { to } 1.8 \\
(4 \text { to } 7)\end{array}$ \\
\hline $\begin{array}{l}\text { Cagampan and Waddington } \\
\text { (2008) (natural site) }\end{array}$ & $\begin{array}{l}-1.3 \text { to }-1.6 \\
(-5 \text { to }-6)\end{array}$ & $\begin{array}{l}3.3 \text { to } 3.8 \\
(12.5 \text { to } 14.5)\end{array}$ & $\begin{array}{l}2.0 \text { to } 2.4 \\
(7.5 \text { to } 9)\end{array}$ \\
\hline Bubier et al. 1998(natural site) & N/A & $\begin{array}{l}2.0 \text { to } 4.2 \\
(7.7 \text { to } 15.8)\end{array}$ & $\begin{array}{l}0.9 \text { to } 2.0 \\
(3.4 \text { to } 7.6)\end{array}$ \\
\hline Bubier et al. 2003 (natural site) & $\begin{array}{l}-1.0 \text { to }-2.5 \\
(-3.8 \text { to }-9.5)\end{array}$ & $\begin{array}{l}7.5 \text { to } 7.9 \\
(28.5 \text { to } 30.2)\end{array}$ & $\begin{array}{l}5.0 \text { to } 7.0 \\
(19.0 \text { to } 26.6)\end{array}$ \\
\hline $\begin{array}{l}\text { Bellisario and Moore (1998) } \\
\text { (natural site) }\end{array}$ & $\begin{array}{l}-1.9 \text { to } 3.1 \\
(-7.1 \text { to } 11.8)\end{array}$ & $\begin{array}{l}4.0 \text { to } 6.7 \\
(15.3 \text { to } 25.6)\end{array}$ & $\begin{array}{l}0.6 \text { to } 2.1 \\
(2.2-8.0)\end{array}$ \\
\hline $\begin{array}{l}\text { Waddington and Warner } \\
\text { (2001) (natural site) }\end{array}$ & N/A & $\begin{array}{l}1.7 \text { to } 3.8 \\
(6.5 \text { to } 14.4)\end{array}$ & $\begin{array}{l}1.5 \text { to } 2.6 \\
(5.5 \text { to } 9.8)\end{array}$ \\
\hline
\end{tabular}




\subsection{Methane flux at U-shaped cells and natural site during 2009}

At the U-shaped cells, no trend in $\mathrm{CH}_{4}$ flux was noticed for any treatment during the 2009 growing season. The $\mathrm{CH}_{4}$ flux was negligible for both summer and winter treatment, with the exception of cell (L_15_s) (B), which showed slight uptake of $\mathrm{CH}_{4}$ towards the end of the season. The reason for such small $\mathrm{CH}_{4}$ flux during the season is unclear at this time. One possible explanation is that active rewetting of the cells with oxygenated water does not allow anoxic conditions to persist for suitable length of time to allow $\mathrm{CH}_{4}$ production. Another possibility may be the lack of availability of nitrate or ferric oxide, which act as an electron acceptor in the soil redox reaction to trigger $\mathrm{CH}_{4}$ production (Sahrawat 2004).

In contrast, the natural site showed a small and gradual increase in $\mathrm{CH}_{4}$ uptake as the season progressed. The average daily $\mathrm{CH}_{4}$ flux for the natural site during the growing season fluctuated between $-2.4 \mathrm{mg} \mathrm{CH} \mathrm{m}^{-2}$ day $^{-1}$ and $-2.9 \mathrm{mg} \mathrm{CH}_{4} \mathrm{~m}^{-2}$ day ${ }^{-1}$. The total $\mathrm{CH}_{4}$ uptake from natural site during the 2009 growing season was $-159.4 \mathrm{mg} \mathrm{CH}_{4} \mathrm{~m}^{-2}$. In comparison, Waddington and Day (2007) recorded a seasonal flux of approximately $100.0 \mathrm{mg} \mathrm{CH}_{4} \mathrm{~m}^{-2}$ during the period from early May to mid October for a restored site in Quebec. The natural sites were drained before the live summer and winter treatments were extracted from the surrounding area. Hence, its water table depth was considerably lower than many of the undisturbed natural boreal bogs (Leppala et al. 2010). Therefore, it is likely that whatever $\mathrm{CH}_{4}$ production occurring below the water table, was offset by $\mathrm{CH}_{4}$ oxidation within the aerobic surface peat layers. Another possibility is that during drier conditions mineralization takes places and results in higher concentrations of 
nitrogen. However, during precipitation events either flushing of nitrogen occurs or nitrifying bacteria was not able to compete with methanotrophic bacteria. Hence, during that time consumption of $\mathrm{CH}_{4}$ as the energy and carbon source by bacterial community increases. This further reduces $\mathrm{CH}_{4}$ concentrations and allows the site to act as a sink for $\mathrm{CH}_{4}$ (Bayley and Thormann 2005; Mewhort 2000; Megraw and Knowles 1987). In Finland, Tuittila et al. (2000) found that under lower water depth, the $\mathrm{CH}_{4}$ production was limited. However, when water table depth was increased by continuous rewetting then increase in $\mathrm{CH}_{4}$ was noticed due to decrease in methane and peat oxidation. Sundh et al. (2000) also found that after drainage, $\mathrm{CH}_{4}$ production decreases due to reduced zone for anerobic respiration. It was observed that $\mathrm{CH}_{4}$ emissions were significantly higher from the drainage ditches in comparison to mined strips. 


\subsection{Conclusions and Recommendations}

As described in previous studies (Waddington et al. 2010; Holden et al. 2005; Waddington and Warner 2001; Bubier et al. 1998), LAI, soil temperature and soil moisture content played important roles in controlling the NEE, R, and GEP at the Ushaped cells one year after transplantation. All treatments, except for natural sites, acted as a source of $\mathrm{CO}_{2}$ during the early summer. However, from mid-summer, NEE declined $\left(\mathrm{CO}_{2}\right.$ uptake increased) for all the treatments except for the live winter treatments and natural sites. Active watering during mid-summer and late summer resulted in saturated conditions and decreased respiration presumably through reduced rates of aerobic heterotrophic respiration. In a number of treatments a direct relationship was observed in between $\mathrm{LAI}$ and increase in $\mathrm{CO}_{2}$ uptake. However, in some cases, increases in GEP were noticed even during periods with decreased LAI. This particular trend may in part be due to error with the pin drop LAI techniques that result in underestimation during strong winds.

Another possible source of error which may have an effect on the quality of the data during the growing season is that each treatment's flux and environmental variables were monitored at only two collar locations. This may not be an ideal representation of GEP, R, NEE and environmental parameters from the cell with an area of $200 \mathrm{~m}^{2}$. In future three to four collars could be installed in order to increase confidence in the results. It may also be ideal to reduce the disturbance level in each cell by planting the vegetation within the reach of boardwalks. 
In future studies, mineral soil treatments and peat mix with mine water treatments need to be discontinued or should be modified by diluting the concentration of mine water and by reducing the hardness of the mineral soil treatments as no significant GEP or $\mathrm{R}$ were noticed for these two treatments during the season.

It is important to notify the fact that GEP results in this study are biased and the success of a particular treatment cannot be accessed on the basis of GEP or NEE as few treatments had healthier vegetation to start with than other treatments. Also, certain collars had specific species which were better able to adapt or had greater number of species to begin with. Hence, it will be biased to decide success of the treatment on the basis of the GEP or NEE values. In contrast, $R$ was a good indicator of the health of the soil in different treatments. For example, the respiration values of live summer treatments showed that soil had a soil structure and healthier microbial population than the peat mix soil treatments. In future year, heterotrophic respiration can be found by removing the roots of the vegetation. Therefore, at this instance, it would not be appropriate at this instance to decide the success of the live and peat mix treatments. Further research, will help scientist to better understand to processes.

In the case of $\mathrm{CH}_{4}$, no notable trends were identified. The reason for no $\mathrm{CH}_{4}$ is unclear this stage. However, watering may not allow anoxic conditions to persist for a time period, which is required for $\mathrm{CH}_{4}$ production. The validity of the assumption can be confirmed in future years by discontinuing the watering in a few cells and by measuring redox potential at various treatments.

The role of surface controls on net carbon balance in wetlands has not been examined before in Fort McMurray, and this study provides the first assessment of 
environmental variables on the NEE of different treatments. This research will provide baseline information on reclamation practices in future years. The results from this study will also be crucial in the development of the one of the largest man made fens scheduled to begin construction in Fort McMurray in 2011. Further research is required to establish whether the use of live transplants for reclamation practices is a cost-effective and useful approach or not. However, at this current time there is an indication that in terms of soil structure and microbial communities live summer treatment is better than other treatments. Therefore, the U-shaped cells require monitoring for the next few years to better understand how peat properties, decomposition rates, and vegetation changes with time. 


\subsection{References}

Aerts R, Ludwig F. 1997. Water table changes and nutritional status affect trace gas emissions from laboratory columns of peatland soils. Soil biology and Biochemistry 29:1691-1698.

Ahlholm U, Silvola, J. 1990. $\mathrm{CO}_{2}$ release from peat-harvested peatlands and stockpiles. In: International Conference on Peat Production and Use, 11-15 June 1990, Volume 2. Jyva“ skyla“ , Finland, pp. 1-12.

Alberta Geological Survey 2008. Alberta Oil Sands. http://www.ags.gov.ab.ca/activities/CBM/alberta_oil_sands.html. Date accessed: February 10th 2009.

Alm J, Schulman L, Walden J, Nykanen H, Martikainen PJ, Silova J. 1999. Carbon balance of a boreal bog during a year with an exceptionally dry summer. Ecology 80:161-74.

Aurela M, Riutta T, Laurila T, Tuovinen JP, Vesala T, Tuittila ES, Rinne J, Haapanala S, Laine J. 2007. $\mathrm{CO}_{2}$ balance of a sedge fen in southern Finland- the influence of a drought period. Tellus 59B:826-837.

Aurela M, Laurila T, Tuovinen J-P. 2001. Seasonal $\mathrm{CO}_{2}$ balances of a subarctic mire. Journal of Geophysical Research 106:1623-37.

Bayley SE, Thormann MN. 2005. Nitrogen mineralization and decomposition in western boreal bog and fen peat. Ecoscience 12:455-465.

Bellisario LM, Bubier JL, Moore TR, Chanton JP.1999. Controls on $\mathrm{CH}_{4}$ emissions from a northern peatland. Global Biogeochemical Cycles 13:81-91.

Bellisario LM, Moore TR, Bubier JL. 1998. Net ecosystem $\mathrm{CO}_{2}$ exchange in a boreal peatland, northern Manitoba. Ecoscience 5:534-41.

Blodau C. 2002 Carbon cycling in peatlands-a review of processes and controls. Environmental Reviews 10: 111-134.

Bridgham SD, Megonigal JP, Keller JK, Bliss NB, Trettin C. 2006. The carbon balance of North American wetlands. Wetlands 26:889-916.

Brown SM, Petrone RM, Mendoza C, Devito KJ. 2010. Surface vegetation controls on evapotranspiration from a sub-humid Western Boreal Plain wetland. Hydrological Processes 24:1072-1085. 
Bubier JL, Moore T, Savage K, Crill P. 2005. A comparison of methane flux in a boreal landscape between a dry and a wet year. Global Biogeochemical Cycles 19:1-11.

Bubier JL, Bhatia G, Moore TR, Roulet NT, Lafleur PM. 2003. Spatial and Temporal Variability in Growing-Season Net Ecosystem Carbon Dioxide Exchange at a large Peatland in Ontario, Canada. Ecosystems 6:353-367.

Bubier JL, Crill PM, Moore TM, Savage K, Varner RK. 1998. Seasonal patterns and controls on net ecosystem $\mathrm{CO}_{2}$ exchange in a boreal peatland complex. Global Biogeochemical Cycles 12: 703-714.

Bubier JL, Moore TR, Bellisario L, Comer N, Crill P. 1995. Ecological controls on methane emissions from a northern peatland complex in the zone of discontinuous permafrost, Manitoba, Canada. Global Biogeochemical Cycles 9:455-471.

Bugnon JL, Rochefort L, Price JS. 1997. Field experiment of Sphagnum reintroduction on a dry abandoned peatland in eastern Canada. Wetlands 17: 513-517.

Busch J, Losch R. 1999. The gas exchange of Carexspecies from eutrophic wetlands and its dependence on microclimatic and soil wetness conditions. Physics and the Chemistry of the Earth(B) 24:117-20.

Cagampan JP, Waddington JM. 2008. Net ecosystem $\mathrm{CO}_{2}$ exchange of a cutover peatland rehabilitated with a transplanted acrotelm. Ecoscience 15:258-267.

Campbell DI, Williamson JL.1997. Evaporation from a raised peat bog. Journal of Hydrology 193:142-160.

Carey S. 2008. Growing season energy and water exchange from an oil sands overburden reclamation soil Cover, Fort McMurray, Alberta, Canada. Journal of Hydrological Processes 22: 2847-2857.

Cleary J, Nigel R, Moore T. 2005. Greenhouse gas emissions from Canadian peat extraction, 1990-2000: A life-cycle analysis. Ambio 34:456-461.

Chanton JP, Martens CS,Kelley CA, Crill PM, Showers WJ. 1992. Methane transport mechanisms and isotopic fractionation in emergent macrophytes of an Alaskan tundra lake. Journal of Geophysical Research 97:681-688.

Chapman SJ, Thurlow M. 1996. The influence of climate on $\mathrm{CO}_{2}$ and $\mathrm{CH}_{4}$ emissions from organic soils. Agricultural and Forest Meteorology 79:205-217.

Chimner RA. 2004. Soil respiration rates of tropical peatlands in Micronesia and Hawaii. Wetlands 24: 51-56. 
Christensen TR, Panikov N, Mastepanov M, Joabsson A, Steward A, Oquist M, Sommerkorn M, Reynaud S, Svensson B. 2003. Biotic controls on $\mathrm{CO}_{2}$ and $\mathrm{CH}_{4}$ exchange in wetlands-A closed environment study. Biogeochemistry 64:337-354.

Christensen TR, Jonasson S, Michelsen A, Callaghan TV, Havstrom M. 1998. Environmental controls on soil respiration in the Eurasian and Greenlandic Arctic. Journal of Geophysical Research 103:15-29.

Clymo RS. 1983. Peat. In Gore, A.J.P., editor, Ecosystems of the world 4A. Mires: swamps, bog, fen and moor. Amsterdam: Elsevier 159-224.

Dise NB, Gorham E, Verry ES. 1993. Environmental factors controlling methane emissions from peatlands in Northern Minnesota. Journal of Geophysical Research 10:583-594.

Dove A, Roulet NT, Crill PM, Chanton J, Bourbonniere R.1999. Methane dynamics of a northern boreal beaver pond, Ecoscience 6:577- 586 .

Environmental Canada. 2007. Canadian Climate Normals, Metrological service of Canada.

Elshorbagy A, Jutla A, Barbour L, Kells J. 2005. System dynamics approach to assess the sustainability of reclamation of disturbed watersheds. Canadian Journal of Civil Engineering 32: 144-158.

Ferland C, Rochefort L.1997. Restoration techniques for Sphagnum-dominated Peatlands. Canadian Journal of Botony 75:1110-1118.

Frolking S, Roulet NT, Moore TR, Richard PJH, Lavoie M, Muller SD. 2001. Modeling northern peatland decomposition and peat accumulation. Ecosystems 4:479-98.

Frolking S, Bubier JL, Moore TR, Ball T, Bellisario LM, Bhardwaj A, Carroll P, Crill PM, Lafleur PM, McCaughey JH, Roulet NT, Suyker AE, Verma SB, Waddington JM, Whiting GJ. 1998. The relationship between ecosystem productivity and photosynthetically active radiation for northern peatlands. Global Biogeochemical Cycles 12: 115-126.

Glaser PH, Chanton JP, Morin P, Rosenberry DO, Siegel DI, Ruud O, Chasar LI, Reeve AS. 2004. Surface deformations as indicators of deep ebullition fluxes in a large northern peatland. Global Biogeochemical Cycles 18:1-9.

Gorham E. 1991. Northern peatlands: role in the carbon cycle and probable response to climatic warming. Journal of Applied Ecology 1:182-195.

Griffis TJ, Rouse WR, Waddington JM. 2000. Interannual variability of net ecosystem $\mathrm{CO}_{2}$ exchange at a subarctic fen. Global Biogeochemical Cycles 14:1109-21. 
Grigal DF. 2000. Effects of extensive forest management on soil productivity. Forest Ecology and Management 138:167-185.

Groendahl L, Friborg T, Soegaard H. 2007. Temperature and snow-melt controls on interannual variability in carbon exchange in the high Arctic. Theoretical and Applied Climatology 88: 111-125.

Groot A. 1998. Physical effects of site disturbance on peatlands. Canadian Journal of Soil Science 78: 45-50.

Holden J. 2005. Peatland hydrology and carbon release: why small-scale process matters. Philosophical transactions of the Royal society 363: 2981-2913.

Holden J, Chapman PJ, Labadz JC. 2004. Artificial drainage of peatlands: hydrological and hydrochemical process and wetland restoration. Progress in Physical Geography 28: $95-123$.

International Union for Conservation of Nature (IUCN). 2000. Executive Summary of the World Water Development Report (2000) vision for water and nature. A world strategy for conservation and sustainable management of water resources in the $21^{\text {st }}$ centurycompilation of all project Documents. Cambridge.

Jeglum JK. 1990. Peatland forestry in Canada: An overview, in Biomass Production and Element Fluxes in Forested Peatland Ecosystems, edited by B. Hanell, pp. 19-28, Swedish Univ. of Agricultural Science, Umea, Sweden.

Joabsson A, Christensen TR, Wallen B.1999. Vascular plant controls on methane emissions from northern peat-forming wetlands. Trends in Ecology and Evolution $14: 385-388$.

Joiner DW, Lafleur PM, McCaughey JH, Bartlett PA. 1999. Interannual variability in corbon dioxide exchanges at a boreal wetland in the BOREAS northern study area. Journal of Geophysical Research 104:663-672.

Kennedy G, Mayer T. 2002. Natural and Constructed Wetlands in Canada: An Overview. Water Quality Research Journal of Canada 37:295-325.

Kettunen A, Kaitala V, Alm J, Silvola J, Nykanen H, Martikainen PJ. 1996. Crosscorrelation analysis of the dynamics of methane emissions from northern peat-forming wetlands. Global Biogeochemical Cycles 10:457-471.

Keys D. Canadian peat harvesting and the environment, 1992. Report, 1992-93, North American Wetlands Conservation Council, Ottawa, Canada. 
King JY, Reeburgh WS, Thieler KK, Kling GW, Loya WM, Johnson LC, Nadelhoffer KJ.2002. Pulse-labeling studies of carbon cycling in Arctic tundra ecosystems: The contribution of photosynthates to methane emission, Global Biogeochemical Cycles 16: $1-8$.

King JY, Reeburgh WS, Regli SK.1998. Methane emission and transport by arctic sedges in Alaska: Results of a vegetation removal experiment, Journal of Geophysical Research 103:83-92.

Komulainen VM, Tuittila ES, Vasander H, Laine J. 1999. Restoration of drained peatlands in southern Finland: Initial effects on vegetation change and $\mathrm{CO}_{2}$ balance. Journal of Applied Ecology 36: 634-648.

Lafleur PM. 2009. Connecting Atmosphere and Wetland: Trace Gas Exchange. Geography Compass 3:560-585.

Lafleur PM. 2008. Connecting Atmosphere and Wetland: Energy and Water Vapour Exchange. Geography Compass 2:1027-1057.

Lafleur PM, Roulet NT, Bubier JL, Frolking S, Moore TR. 2003. Interannual variability in the peatland-atmosphere carbon dioxide exchange at an ombrotrophic bog. Global Biogeochemical Cycles 17:1036.

Lafleur PM, Griffis TJ, Rouse WR. 2001. Interannual variability in net ecosystem $\mathrm{CO}_{2}$ exchange at the arctic treeline. Arctic, Antarctic, and Alpine Research 33:149-57.

Laine J, Minkkinen K. 1996. Effect of forest drainage on the carbon balance of a mire: A case study. Scandinavian Journal of Forest Research 11:307-312.

Lehner B, Döll P. 2004. Development and validation of a global database of lakes, reservoirs and wetlands. Journal of Hydrology 296: 1-22.

MathWorks, Inc. 2007. Matlab Software: Version 7.4 (2007). Natick, MA.

Meerveld HJ, McDonnell JJ. 2006. On the interactions between the spatial patterns of topography, soil moisture, transpiration and species distribution at the hillslope scale. Advances in Water Resources 29: 293-310.

Megraw SR, Knowles R. 1987. Active methanotrops suppress nitrification in a humisol. Biology and Fertility of Soils 4: 205-212.

Mendenhall W, Beaver RJ, Beaver BM. 1999. Introduction to Probability and Statistics. Duxbury Press, United states, pp. 453-500. 
Mewhort RL. 2000. Nitrogen dynamics and ecological characteristics in marshes and fens in boreal Alberta, Canada. M.Sc thesis, Biological Sciences Department, University of Alberta, Edmonton, Alberta.

Moore TR, Lafleur PM, Poon DMI, Heumann BW, Seaquist JW, Roulet NT. 2006 Spring photosynthesis in a cool temperate bog. Global Change Biology 12:23232335.

Moore TR, Dalva M. 2001. Some controls on the production of dissolved organic carbon in soils. Journal of Soil Science 166:38-47.

Moore TR, Dalva M. 1993. Influence of temperature and water table position on carbon dioxide and methane emissions from columns of peatland soils. Journal of Soil Science 44:651-64.

National Wetland Working Group. 1997. The Canadian Wetland Classification System, 2nd edn, Warner BG, Rubec CDA (eds). Wetland Research Centre

Publication:Waterloo, ON, 68p.

Nobel PS, Zaragoza LJ, Smith WK. 1975. Relation between Mesophyll Surface Area, Photosynthetic Rate, and Illumination Level during Development for Leaves of Plectranthus parviflorus Henckel. Plant Physiology 55:1067-1070.

Oechel WC, Vourlitis GL, Hastings SJ, Bochkarev SA. 1995. Effects of climate change at Barrow, Alaska. Journal of Applied Ecology 5:846-855.

Payette S, Rochefort L. 2001. Écologie des tourbières du Québec-Labrador. Les Presses de l'Université Laval. Québec, Québec.

Petrone RM, Solondz DS, Macrae ML, Gignac D, Devito KJ. 2011. Microtopographical and canopy cover controls on moss carbon dioxide exchange in a western Boreal Plain peatland. Ecohydrology 4: 115-129.

Price JS, Heathwaite AL, Baird AJ. 2003. Hydrological processes in abandoned and restored peatlands: an overview of management approaches. Wetlands Ecology and Management 11:65-83.

Price JS, Whitehead GW. 2001. Developing hydrological thresholds for Sphagnum recolonization on an abandoned cutover bog. Wetlands 21: 32-42.

Price JS, Waddington JM. 2000. Advances in Canadian wetland hydrology and biogeochemistry, 1995-1998. Hydrological Processes 14: 1579-1589.

Pothier D. 2000. Ten-year results of stripclear-cutting in Quebec black spruce stands. Canadian Journal for Forest Research 30: 59-66. 
Quinty F, Rochefort L. 2003. Peatland Restoration Guide, second edition, draft. Canadian Sphagnum Peat Moss Association and New Brunswick Department of Natural Resouces and Energy, Quebec, QC.

Rosenberry DO, Glaser PH, Siegel DL, Weeks EP. 2003. Use of hydraulic head to estimate volumetric gas content and ebullition flux in northern peatlands. Water Resources Research 39: 1-10.

Roulet NT, Lafleur P, Richard P, Moore T, Humphreys E, Bubier J.2007. Contemporary carbon balance and late Holocene carbon accumulation in a northern peatland. Global Change Biology 13:397-411.

Sachs PD. 1999. Edaphos : Dynamics of a Natural Soil System. Edaphic Press, USA.

Sahrawat KL. 2004. Iron toxicity in wetland rice and the role of other nutrients. Journal of Plant Nutrition 27:1471-1504.

Sall J, Creighton L, Lehman A. 2005. JMP Start Statistics: A Guide to Statistics and Data Analysis Using JMP. SAS press, United states of America, pp. 210-490.

Scanlon D, Moore T. 2000. Carbon dioxide production from peatland soil profiles: the influence of temperature, oxic/anoxic conditions and substrate. Soil Science 165:153-60.

Shurpali NJ, Verma SB, Kim J.1995. Carbon dioxide exchange in a peatland ecosystem. Journal of Geophysical research 14:319-326.

Silvola J, Alm J, Ahlholm U, Nykanen H, Martikainen PJ. 1996. $\mathrm{CO}_{2}$ fluxes from peat in boreal mires under varying temperature and moisture conditions. Ecology 84:219-28.

Silvola J. 1986. Carbon dioxide dynamics in mires reclaimed for forestry in eastern Finland. Annales Botanici Fennici 23:59- 67.

Strack M, O'Brien J, Waddington JM. 2008. Assessing the role of ecological succession for peatland methane dynamics: Potential climate change feedback. In Proceedings of the 13th International Peat Congress, volume 1, Farrell C, Feehan J, (eds), International Peat Society, Jyväskylä, Finland, pp. 637-640.

Strack M, Waddington JM, Tuittila ES. 2004. Effect of water table drawdown on northern peatland methane dynamics: Implications for climate change. Global Biogeochemical Cycles 18: 1-7.

Strack M, Waddington JM, Tuittila ES, Kellner E, Price JS, Rochefort L. 2003. Methane emissions and storage at a natural and drained peatland fen in central Quebec. Jarvet E, Lode E. (eds) Proceedlings of the international conference on ecohydrological processes in northern wetlands. Tartu University Press, Tallinn, pp 227-232. 
Strom L, Ekberg A, Mastepanov M, Christensen TR. 2003. The effect of vascular plants on carbon turnover and methane emissions from a tundra wetland, Global Change Biology 9:1-8.

Sundh I, Nilsson M, Mikkela C, Granberg G, Svensson B. 2000. Fluxes of methane and carbon dioxide on peat-mining in Sweden. Ambio 29: 499-503.

Tarnocai C. 1988. Canadian wetland registry. In Proceedings Workshop on Canadian Wetlands, Rubec CDA, Pollett FC (eds). Ecological Classification Series No. 12, Lands Directorate, Environment Canada: Ottawa, Ontario, 9-30.

Treat CC, Bubier JL, Varner RK, Crill PM. 2007. Timescale dependence of environmental and plant-mediated controls on $\mathrm{CH}_{4}$ flux in temperate fen. Journal of Geophysical Research 112: 1-9.

Tuittila ES, Komulainen VM, Vasander H, Nykanen H, Martikainen PJ, Laine J. 2000. Methane dynamics of a restored cutaway peatland, Global Change Biology 6: 569-581.

Tuittila ES, Komulainen VM, Vasander H, Laine J.1999. Restored cut-away peatland as a sink for atmospheric $\mathrm{CO}_{2}$. Oecologia:120 563- 574.

Waddington JM, Strack M, Greenwood MJ. 2010. Towards restoring the net carbon sink function of degraded peatlands: Short term response in $\mathrm{CO}_{2}$ exchange to ecosystem-scale restoration. Journal of Geophysical Research 115:1-13.

Waddington JM, Plach J, Cagampan JP, Lucchese M, Strack M. 2009. Reducing the Carbon Footprint of Canadian Peat Extraction and Restoration. Ambio 38:194-200.

Waddington JM, Day SM. 2007. Methane emissions from a peatland following restoration. Journal of Geophysical Research 112:1-11.

Waddington JM, Warner KD, Kennedy GW. 2002. Cutover peatlands: A persistent source of atmospheric $\mathrm{CO}_{2}$. Global Biogeochemical Cycles 16:1-7.

Waddington JM, Warner KD. 2001. Atmospheric $\mathrm{CO}_{2}$ sequestration in restored mined peatlands. Ecoscience 8 359-368.

Waddington JM, Price JS. 2000. Effect of peatland drainage, harvesting, and restoration on atmospheric water and carbon exchange. Physical Geography 21: 433-451.

Waddington JM, Roulet NT. 1996. Atmospheric-wetland carbon exchanges: Scale dependency of $\mathrm{CO}_{2}$ and $\mathrm{CH}_{4}$ exchange on the developmental topography of a peatland. Global Biogeochemical Cycles 10:233-245. 
Waddington JM, Roulet NT, Swanson RV.1996. Water table control of CH4 emission enhancement by vascular plants in boreal peatlands. Journal of Geophysical Reasearch 101:775-785.

Welke S, Fyles J. 2006. Compactions of the boreal forest soils. Sustainable forest management network research note series no. 17 .

Weltzin JF, Pastor J, Harth C, Bridgham SD, Updegraff K, Chapin CT. 2000. Response of bog and fen plant communities to warming and water table manipulations. Ecology 81:3464-78.

Whiting GJ, Chanton JP. 2001. Greenhouse carbon balance of wetlands: methane emission versus carbon sequestration. Tellus 53B:521-8.

Wilson S, Griffiths M, Anielski M. 2001. The Alberta GPI Accounts: Wetlands and Peatlands. The Pembina Institute Report 23.

Zoltai SC. 1988. Late Quaternary volcanic ash in the peatlands of central Alberta. Canadian Journal of Earth Sciences 26: 207-214. 